Prepared in cooperation with the North Dakota Department of Transportation and the North Dakota State Water Commission

\title{
Hydrographic Surveys of the Missouri and Yellowstone Rivers at Selected Bridges and through Bismarck, North Dakota, during the 2011 Flood
}

Scientific Investigations Report 2013-5087 
Cover. Front cover: The West Bismarck Expressway Bridge, Bismarck, North Dakota, on June 6, 2011. Photograph by Richard J. Huizinga, U.S. Geological Survey (USGS).

Inset: U.S. Geological Survey collecting hydrographic survey data on the Missouri River at Williston Bridge near Williston, North Dakota, on June 8, 2011. Photograph by William C. Damschen, USGS.

Back cover: Homes on the left bank of the Missouri River on July 8, 2011, in Bismarck, North Dakota. Photograph by Brenda K. Densmore, USGS. 


\section{Hydrographic Surveys of the Missouri and Yellowstone Rivers at Selected Bridges and through Bismarck, North Dakota, during the 2011 Flood}

By Brenda K. Densmore, Kellan R. Strauch, and Benjamin J. Dietsch

Prepared in cooperation with the North Dakota Department of Transportation and the North Dakota State Water Commission

Scientific Investigations Report 2013-5087 


\title{
U.S. Department of the Interior SALLY JEWELL, Secretary
}

\section{U.S. Geological Survey \\ Suzette M. Kimball, Acting Director}

\author{
U.S. Geological Survey, Reston, Virginia: 2013
}

For more information on the USGS - the Federal source for science about the Earth, its natural and living resources, natural hazards, and the environment, visit http://www.usgs.gov or call 1-888-ASK-USGS.

For an overview of USGS information products, including maps, imagery, and publications, visit http://www.usgs.gov/pubprod

To order this and other USGS information products, visit http://store.usgs.gov

Any use of trade, firm, or product names is for descriptive purposes only and does not imply endorsement by the U.S. Government.

Although this information product, for the most part, is in the public domain, it also may contain copyrighted materials as noted in the text. Permission to reproduce copyrighted items must be secured from the copyright owner.

Suggested citation:

Densmore, B.K., Strauch, K.R., and Dietsch, B.J., 2013, Hydrographic surveys of the Missouri and Yellowstone Rivers at selected bridges and through Bismarck, North Dakota, during the $2011 \mathrm{flood}$ : U.S. Geological Survey Scientific Investigations Report 2013-5087, 59 p., http://pubs.usgs.gov/sir/2013/5087/. 


\section{Contents}

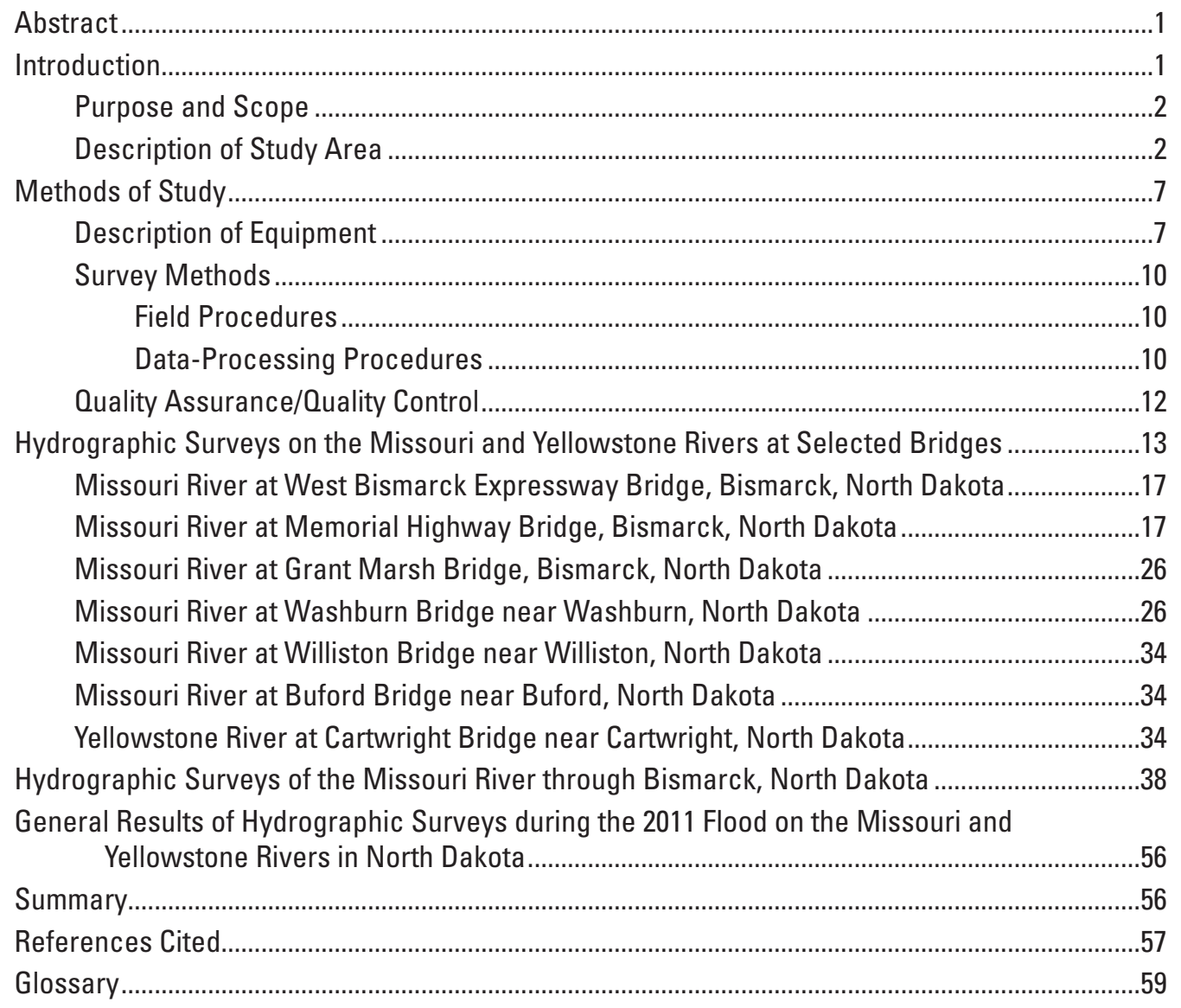

\section{Figures}

1. Map showing the Missouri River basin, dams, reservoirs, and study locations

2. Map showing location of Missouri River bridge survey sectors, survey benchmarks, and U.S. Geological Survey streamgage 06342500 at Bismarck, North Dakota .

3. Map showing location of Missouri River bridge survey area at Washburn Bridge near Washburn, North Dakota, and survey benchmark .

4. Map showing location of Missouri and Yellowstone River bridge survey areas, survey benchmarks, and U.S. Geological Survey streamgage 06330000 near Williston, North Dakota.

5. Photographs showing hydrographic surveying using multibeam echosounder systems as installed on USGS-Nebraska boat with sonar head rotated out of water and sonar head submerged during data collection, and on USGS-Missouri boat with sonar head rotated out of the water and sonar head submerged during data collection 
6. Photographs showing RESON SeaBat ${ }^{\mathrm{TM}} 7125$ multibeam echosounder components that are submerged during data collection, shown as bottom view and top oblique view.

7. Schematic diagram showing high-resolution multibeam echosounder system components

8. Diagrams showing effects of timing offset for latency, and angular offsets for roll, pitch, and yaw on data from a multibeam echosounder.....

9. Map showing channel-bed elevations from the Missouri River hydrographic survey at West Bismarck Expressway Bridge, Bismarck, North Dakota, June 6, 2011. ...18

10. Map showing channel-bed elevations from the Missouri River hydrographic survey at West Bismarck Expressway Bridge, Bismarck, North Dakota, July 3, 2011

11. Map showing difference in channel-bed elevations between the June 6 and July 3, 2011, hydrographic surveys of the Missouri River at West Bismarck Expressway Bridge, Bismarck, North Dakota.

12. Map showing channel-bed elevations from the Missouri River hydrographic survey at Memorial Highway Bridge, Bismarck, North Dakota, June 7, 2011.

13. Map showing channel-bed elevations from the Missouri River hydrographic survey at Memorial Highway Bridge, Bismarck, North Dakota, July 3, 2011.

14. Map showing difference in channel-bed elevations between June 7 and July 3, 2011, hydrographic surveys on the Missouri River at Memorial Highway Bridge, Bismarck, North Dakota

15. Map showing channel-bed elevations from the Missouri River hydrographic survey at Grant Marsh Bridge, Bismarck, North Dakota, June 6, 2011

16. Map showing channel-bed elevations from the Missouri River hydrographic survey at Grant Marsh Bridge, Bismarck, North Dakota, July 5, 2011.

17. Map showing difference in channel-bed elevations between June 6 and July 5 , 2011, hydrographic surveys on the Missouri River at Grant Marsh Bridge, Bismarck, North Dakota ...

18. Map showing channel-bed elevations from the Missouri River hydrographic survey at Washburn Bridge, near Washburn, North Dakota, June 9, 2011.

19. Map showing channel-bed elevations from the Missouri River hydrographic survey at Washburn Bridge, near Washburn, North Dakota, July 9, 2011

20. Map showing difference in channel-bed elevations between June 9 and July 9 , 2011, hydrographic surveys on the Missouri River at Washburn Bridge near Washburn, North Dakota.

21. Photographs and diagrams showing results of hydrographic survey on July 9, 2011, of middle pier of Washburn Bridge near Washburn, North Dakota, showing exposed footing......

22. Map showing channel-bed elevations from the Missouri River hydrographic survey at Williston Bridge near Williston, North Dakota, June 8, 2011.

23. Map showing channel-bed elevations from the Missouri River hydrographic survey at Buford Bridge near Buford, North Dakota, June 8, 2011.

24. Map showing channel-bed elevations from the Yellowstone River hydrographic survey at Cartwright Bridge near Cartwright, North Dakota, June 8, 2011

25. Graph showing daily mean discharge for the Missouri River at Bismarck, North Dakota, streamgage 06342500, May 15 through August 15, 2011

26. Map showing channel-bed elevations from the Missouri River hydrographic survey of sectors 1 and 2 located south of Bismarck, North Dakota, June 28 and July 2, 2011 
27. Map showing channel-bed elevations from the Missouri River hydrographic survey of sectors 3 and 4 located south of Bismarck, North Dakota, June 29 and July 1, 2011

28. Map showing channel-bed elevations from the Missouri River hydrographic survey of sector 5 located south of Bismarck, North Dakota, June 29, 2011

29. Map showing channel-bed elevations from the Missouri River hydrographic survey of sector 6 located south of Bismarck, North Dakota, June 29, 2011 ...

30. Map showing channel-bed elevations from the Missouri River hydrographic survey of sector 7 located at Bismarck, North Dakota, July 3, 2011

31. Map showing channel-bed elevations from the Missouri River hydrographic survey of sector 8 located at Bismarck, North Dakota, July 3, 2011

32. Map showing channel-bed elevations from the Missouri River hydrographic survey of sector 9 located at Bismarck, North Dakota, July 3, 2011

33. Map showing channel-bed elevations from the Missouri River hydrographic survey of sector 10 located at Bismarck, North Dakota, July 2, 2011

34. Map showing channel-bed elevations from the Missouri River hydrographic survey of sectors 11 and 12 located at Bismarck, North Dakota, July 5, 2011

35. Map showing channel-bed elevations from the Missouri River hydrographic survey of sector 13 located north of Bismarck, North Dakota, July 6, 2011 .....

36. Map showing channel-bed elevations from the Missouri River hydrographic survey of sector 14 located north of Bismarck, North Dakota, July 6, 2011

37. Map showing channel-bed elevations from the Missouri River hydrographic survey of sector 15 located north of Bismarck, North Dakota, July 6-7, 2011

38. Map showing channel-bed elevations from the Missouri River hydrographic survey of sector 16 located north of Bismarck, North Dakota, July 7, 2011

39. Map showing channel-bed elevations from the Missouri River hydrographic survey of sector 17 located north of Bismarck, North Dakota, July 7, 2011

40. Map showing channel-bed elevations from the Missouri River hydrographic survey of sector 18 located north of Bismarck, North Dakota, July 8, 2011 .....

41. Map showing channel-bed elevations from the Missouri River hydrographic survey of sector 19 located north of Bismarck, North Dakota, July 8, 2011

42. Map showing channel-bed elevations from the Missouri River hydrographic survey of sector 20 located north of Bismarck, North Dakota, July 8, 2011 .

\section{Tables}

1. RESON SeaBat ${ }^{\mathrm{TM}} 7125$ specifications for the multibeam echosounder used for hydrographic surveys, 2011

2. Dates and locations of hydrographic surveys at bridge sites and sections on the Missouri and Yellowstone Rivers, North Dakota, during the 2011 flood

3. Location and location checks of benchmarks used for hydrographic surveys of the Missouri and Yellowstone Rivers, North Dakota, during the 2011 flood

4. Summary of channel-bed elevations surveyed at selected bridges on the Missouri and Yellowstone Rivers, North Dakota, during the 2011 flood

5. Daily mean gage height and daily mean discharge at selected streamgages during hydrographic surveys of the Missouri and Yellowstone Rivers, North Dakota, during the 2011 flood. 


\section{Conversion Factors}

\begin{tabular}{lcl}
\multicolumn{1}{c}{ Inch/Pound to SI } & \multicolumn{1}{c}{ By } & \multicolumn{1}{c}{ To obtain } \\
\hline & Length & \\
\hline inch (in.) & 2.54 & centimeter $(\mathrm{cm})$ \\
inch (in.) & 25.4 & millimeter $(\mathrm{mm})$ \\
foot (ft) & 0.3048 & meter $(\mathrm{m})$ \\
U.S. survey feet (US ft) & 0.30480061 & meter $(\mathrm{m})$ \\
mile (mi) & 1.609 & kilometer $(\mathrm{km})$ \\
\hline & Flow rate or velocity & \\
\hline cubic foot per second $\left(\mathrm{ft}^{3} / \mathrm{s}\right)$ & 0.02832 & cubic meter per second $\left(\mathrm{m}^{3} / \mathrm{s}\right)$ \\
\hline & Volume & \\
\hline acre-foot $(\mathrm{acre}-\mathrm{ft})$ & 1,233 & cubic meter $\left(\mathrm{m}^{3}\right)$ \\
\hline & Frequency & \\
\hline kilohertz $(\mathrm{kHz})$ & 1,000 & cycle $/$ second \\
\hline
\end{tabular}

Temperature in degrees Fahrenheit $\left({ }^{\circ} \mathrm{F}\right)$ may be converted to degrees Celsius $\left({ }^{\circ} \mathrm{C}\right)$ as follows:

${ }^{\circ} \mathrm{C}=\left({ }^{\circ} \mathrm{F}-32\right) / 1.8$

Vertical coordinate information is referenced to the North American Vertical Datum of 1988 (NAVD 88).

Horizontal coordinate information is referenced to the North American Datum of 1983 Continuously Operating Reference Station 1996 [NAD 83 (CORS 96)].

Elevation, as used in this report, refers to distance above the vertical datum. 


\title{
Hydrographic Surveys of the Missouri and Yellowstone Rivers at Selected Bridges and through Bismarck, North Dakota, during the 2011 Flood
}

\author{
By Brenda K. Densmore, Kellan R. Strauch, and Benjamin J. Dietsch
}

\section{Abstract}

The U.S. Geological Survey (USGS), in cooperation with the North Dakota Department of Transportation and the North Dakota State Water Commission, completed hydrographic surveys at six Missouri River bridges and one Yellowstone River bridge during the 2011 flood of the Missouri River system. Bridges surveyed are located near the cities of Cartwright, Buford, Williston, Washburn, and Bismarck, N. Dak. The river in the vicinity of the bridges and the channel through the city of Bismarck, N. Dak., were surveyed. The hydrographic surveys were conducted using a high-resolution multibeam echosounder (MBES), the RESON SeaBat ${ }^{\mathrm{TM}} 7125$, during June 6-9 and June 28-July 9, 2011. The surveyed area at each bridge site extended 820 feet upstream from the bridge to 820 feet downstream from the bridge. The surveyed reach through Bismarck consisted of 18 miles of the main channel wherever depth was sufficient. Results from these emergency surveys aided the North Dakota Department of Transportation in evaluating the structural integrity of the bridges during high-flow conditions. In addition, the sustained high flows made feasible the surveying of a large section of the normally shallow channel with the MBES.

In general, results from sequential bridge surveys showed that as discharge increased between the first and second surveys at a given site, there was a general trend of channel scour. Locally, complex responses of scour in some areas and deposition in other areas of the channel were identified. Similarly, scour around bridge piers also showed complex responses to the increase in flow between the two surveys. Results for the survey area of the river channel through Bismarck show that, in general, scour occurred around river structures or where the river has tight bends and channel narrowing. The data collected during the surveys are provided electronically in two different file formats: comma delimited text and CARIS Spatial Archive ${ }^{\mathrm{TM}}\left(\mathrm{CSAR}^{\mathrm{TM}}\right)$ format.

\section{Introduction}

The U.S. Geological Survey (USGS), in cooperation with the North Dakota Department of Transportation and the North Dakota State Water Commission, conducted hydrographic surveys near six Missouri River bridges and one Yellowstone River bridge during the 2011 flood in the Missouri River system. Bridges surveyed are located near the cities of Cartwright, Buford, Williston, Washburn, and Bismarck, N. Dak. (figs. 1-4). In addition to surveying the river in the vicinity of the bridges, a survey of the river channel through the city of Bismarck, N. Dak., was conducted.

A riverbed can be changed by the movement of sediment from flowing water. Sediment is both eroded and deposited. The removal of channel-bed sediment and bank material is known as scour and occurs as velocity and shear stress increase, typically with flood passage (Leopold and others, 1964). Channel-bed scour during flood conditions can have a severe effect on river structures. Scour and fill around river infrastructure, such as bridge piers and abutments, as well as water intakes, pipeline crossings, levees, and rivermanagement structures, can potentially cause infrastructure destruction, damage, or instability. Scour is the most frequent cause of bridge failure (Landers and Mueller, 1996). Because of the subsequent refilling of scour holes by sediment deposition as flood passage wanes, specialized methods are needed to measure the lateral and vertical extent of riverbed scour. Previously, sounding rods, sounding weights, single-beam echosounders, and permanently mounted sonar devices have been used to measure scour holes near bridges (Federal Highway Administration, 2011); however, none of these methods provide as much detail as multibeam echosounders.

Multibeam echosounding is a more efficient method for measuring scour than many other survey methods during flood conditions (Federal Highway Administration, 2011). Other survey methods typically do not provide the high quality or 
detailed data provided by multibeam echosounding equipment. The multibeam echosounder (MBES) hydrographic survey system provides a detailed snapshot of the riverbed, which is beneficial not only for understanding current riverbed conditions, but for understanding change and sediment movement when compared to historic and future surveys. MBES data were collected at six Missouri River bridges, at one Yellowstone River bridge, and along 18 miles (mi) of the Missouri River through Bismarck, N. Dak., during the 2011 flood; that is, surveys were conducted June 6-9 and June 28-July 9, 2011. The surveys were intended to provide data on the riverbed conditions needed to understand current scour, infrastructure integrity, and channel form. The flood conditions provided increased water depths and, thereby, an opportunity for surveying even on the normally wide, shallow sections of the Missouri River, making a MBES survey practical. Hydrographic surveys conducted at four bridges on the Missouri River were repeated to detect changes at multiple points in the flood hydrograph. Bridges that were surveyed twice include three bridges in Bismarck and one at Washburn, N. Dak. These bridges were resurveyed because of their locations and the results of the initial surveys.

The 2011 Missouri River system flood was caused by above-normal snowpack in the Rocky Mountains, additional late-season heavy snowfall, and extreme rainfall over large areas of the upper Missouri River Basin. In particular, heavy rainfall in excess of 10 inches (in.) in eastern Montana in late May contributed to an unexpectedly large runoff volume (National Weather Service, 2011). The combined Maythrough-July 2011 runoff for the basin above Sioux City, Iowa, of 34.3 million acre-feet is greater than the total annual runoff in 102 of the 113 years of record (U.S. Army Corps of Engineers, 2011). This unexpected volume of water caused the U.S. Army Corps of Engineers to take emergency measures to lower main-stem reservoir levels to ensure dam safety. Flood conditions began in the upper Missouri River Basin in mid-May, and the Federal Emergency Management Agency (FEMA) officially expanded its emergency declaration to several North Dakota counties along the Missouri River on May 28, 2011 (Federal Emergency Management Agency, 2011). The official end to the 2011 Missouri River flood was declared on October 17, 2011, when river levels from Montana to St. Louis, Missouri, dropped below flood stage.

\section{Purpose and Scope}

This report documents methodology, describes the results, and compares multiple survey results where applicable of the MBES hydrographic surveys conducted at six Missouri River bridges, at one Yellowstone River bridge, and along $18 \mathrm{mi}$ of the Missouri River through Bismarck, N. Dak., during the 2011 flood. The hydrographic surveys around bridge structures were used by the North Dakota Department of Transportation as a tool to evaluate the structural integrity of the bridges and ensure public safety. In areas where multiple surveys were conducted, the data provided information about the changing river conditions throughout the flood. In addition, these hydrographic surveys were conducted to provide baseline information on riverbed elevations for possible comparison to future surveys and to further understand the fluvial geomorphology of the river system.

\section{Description of Study Area}

The hydrographic surveys described in this report occurred at multiple noncontiguous locations in North Dakota. The Missouri River in North Dakota consists of two freeflowing reaches of river separated by an impounded section. The most upstream section extends $50 \mathrm{mi}$ from the Montana/ North Dakota border to the headwaters of Lake Sakakawea (fig. 1). The impounded section, created by Garrison Dam (fig. 1), extends $135 \mathrm{mi}$. The downstream section extends $90 \mathrm{mi}$ from Garrison Dam to the headwaters of Lake Oahe, created by Oahe Dam in South Dakota (fig. 1). Three of the six bridges surveyed are located in the Bismarck area-West Bismarck Expressway Bridge [State highway (ND Hwy) 810], Memorial Highway Bridge (Business Loop I-94), and Grant Marsh Bridge (I-94) (fig. 2). The width of the river at the West Bismarck Expressway Bridge was approximately 1,250 feet (ft); at Memorial Highway Bridge, 1,070 ft; and at Grant Marsh Bridge, $580 \mathrm{ft}$. The other bridge surveyed in the Garrison/Oahe reach is near Washburn, N. Dak., approximately $30 \mathrm{mi}$ downstream from Garrison Dam (fig. 3). The Missouri River channel width in the vicinity of the Washburn Bridge (ND Hwy 200) was estimated to be $1,050 \mathrm{ft}$. Two of the Missouri River bridges surveyed are in northwest North Dakota in the reach from the State border to the headwaters of Lake Sakakawea - the bridge at Buford (ND Hwy 58), where the channel was approximately $720 \mathrm{ft}$ wide, and the bridge at Williston [Federal highway (U.S. Hwy) 85], where the channel was approximately $1,200 \mathrm{ft}$ wide (fig. 4). The Buford Bridge is approximately $1.5 \mathrm{mi}$ downstream from the Montana/ North Dakota border, $2.8 \mathrm{mi}$ upstream from the Yellowstone/ Missouri River confluence, and $1.5 \mathrm{mi}$ southwest of Buford, N. Dak. The bridge near Williston is $5 \mathrm{mi}$ southwest of Williston, N. Dak., approximately $25 \mathrm{mi}$ downstream from the Yellowstone/Missouri River confluence, and approximately 10 mi upstream from Lake Sakakawea; the exact distance depends on water levels in the lake. The Yellowstone River bridge is 2 mi west of Cartwright, N. Dak., on ND Hwy 200 in northwest North Dakota (fig. 4). The Yellowstone River channel width in the vicinity of the Cartwright Bridge was approximately $690 \mathrm{ft}$; the bridge is approximately $8.7 \mathrm{mi}$ upstream from the river mouth. 


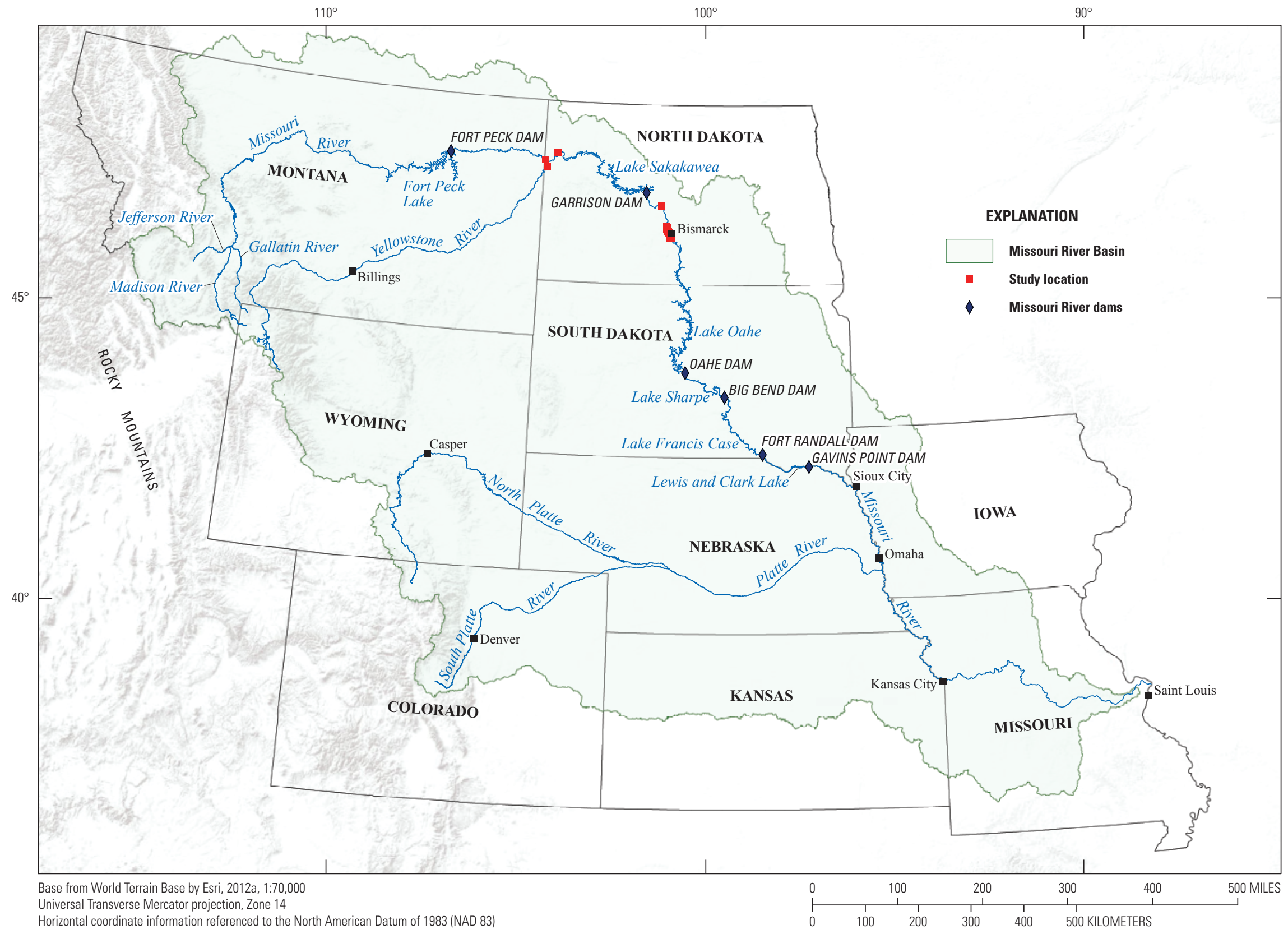

Figure 1. The Missouri River basin, dams, reservoirs, and study locations. 


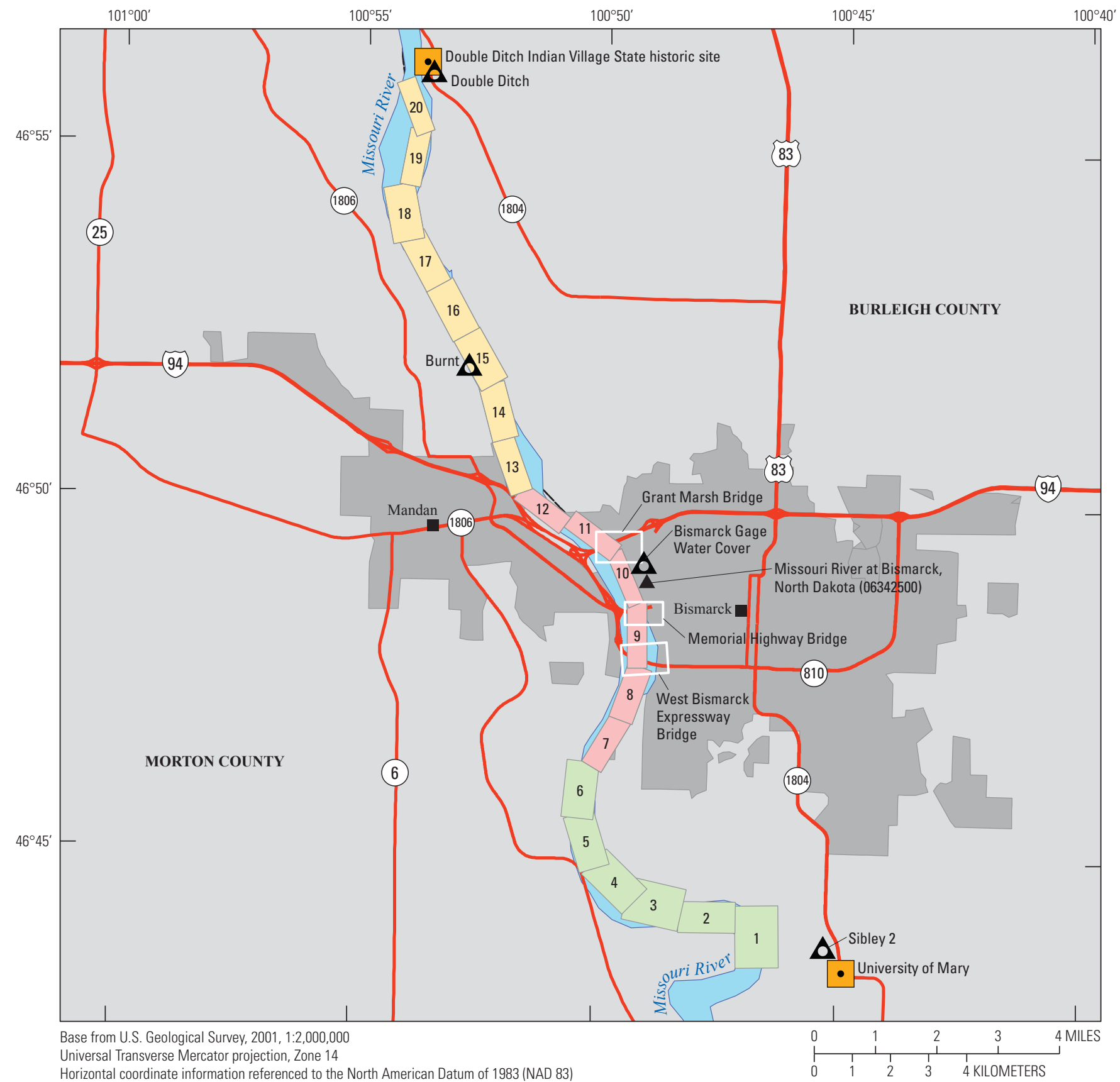

Horizontal coordinate information referenced to the North American Datum of 1983 (NAD 83)

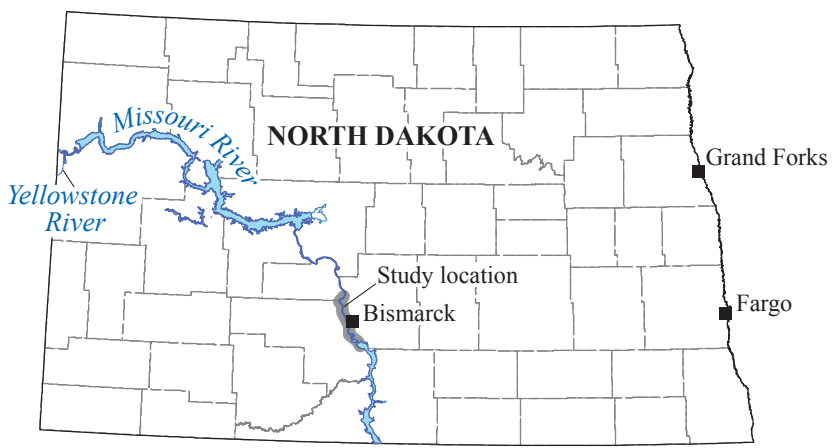

Figure 2. Location of Missouri River bridge survey sectors, survey benchmarks, and U.S. Geological Survey streamgage 06342500 at Bismarck, North Dakota.

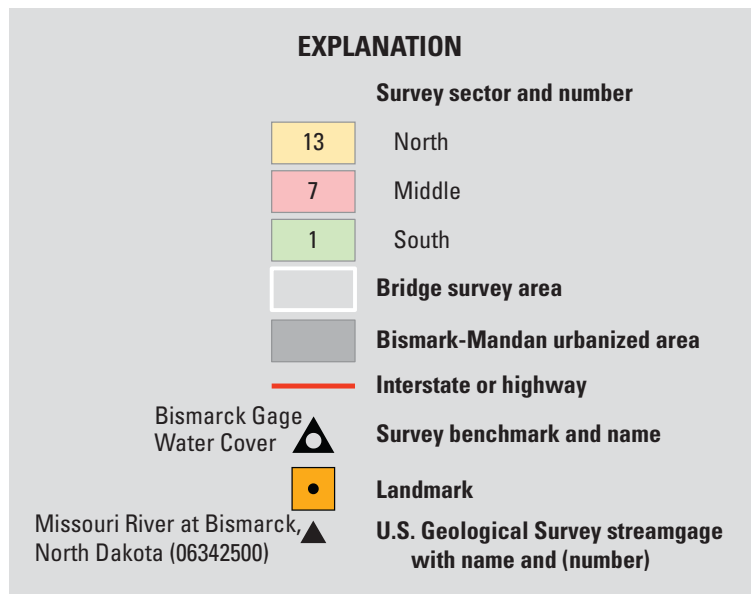



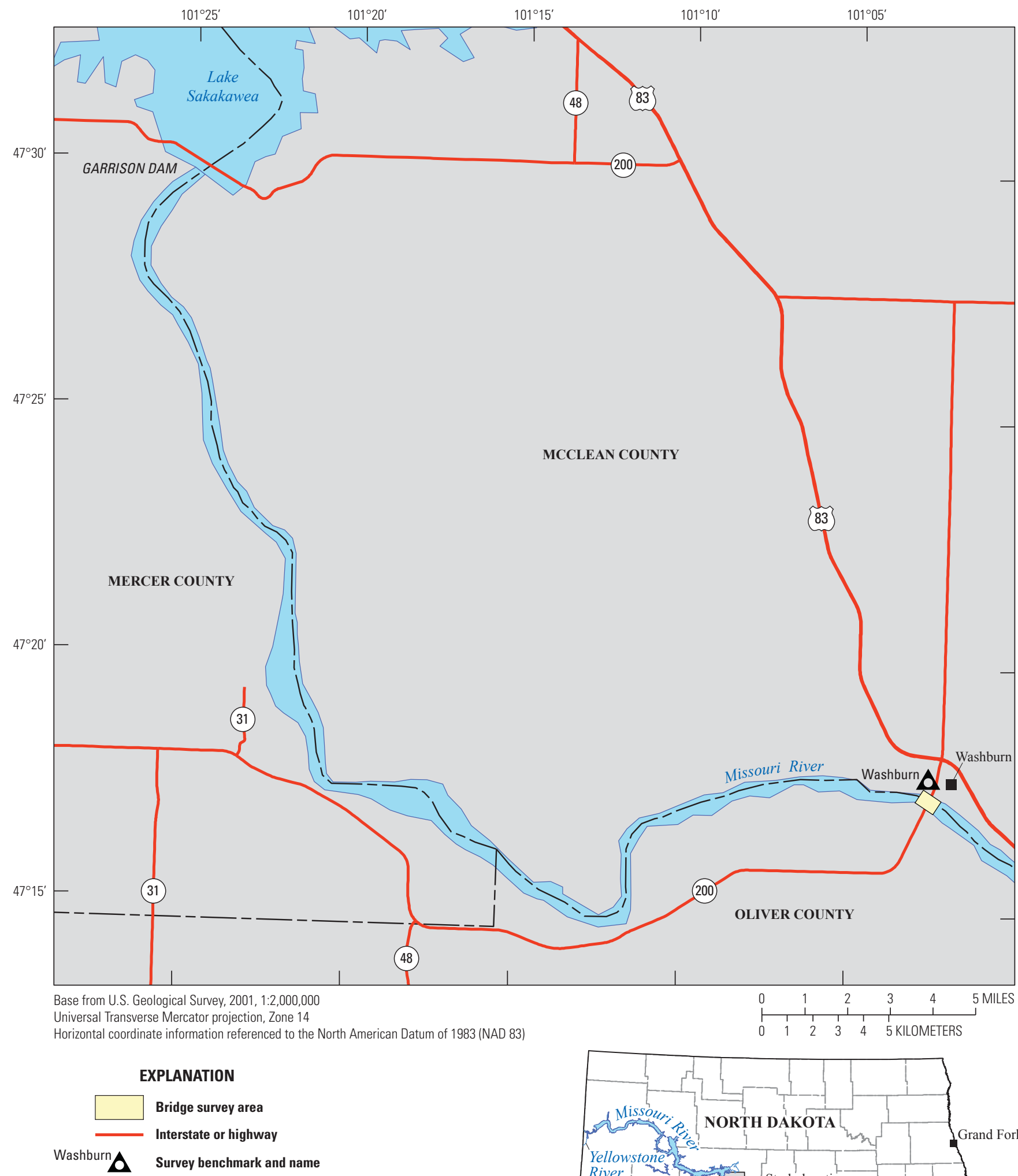

Figure 3. Location of Missouri River bridge survey area at Washburn Bridge near Washburn, North Dakota, and survey benchmark.

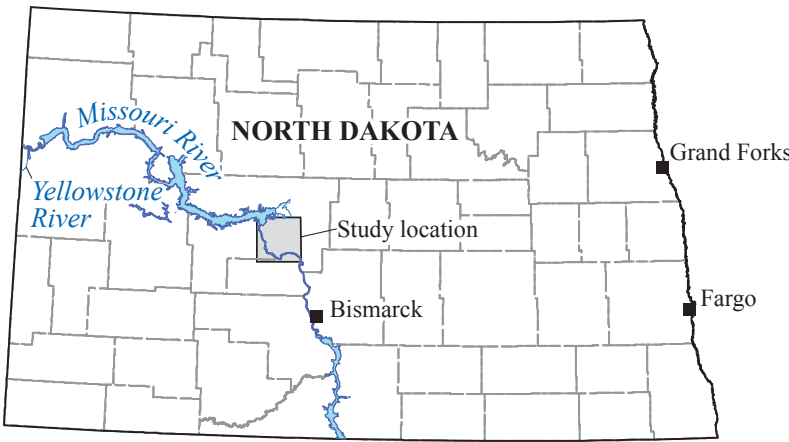




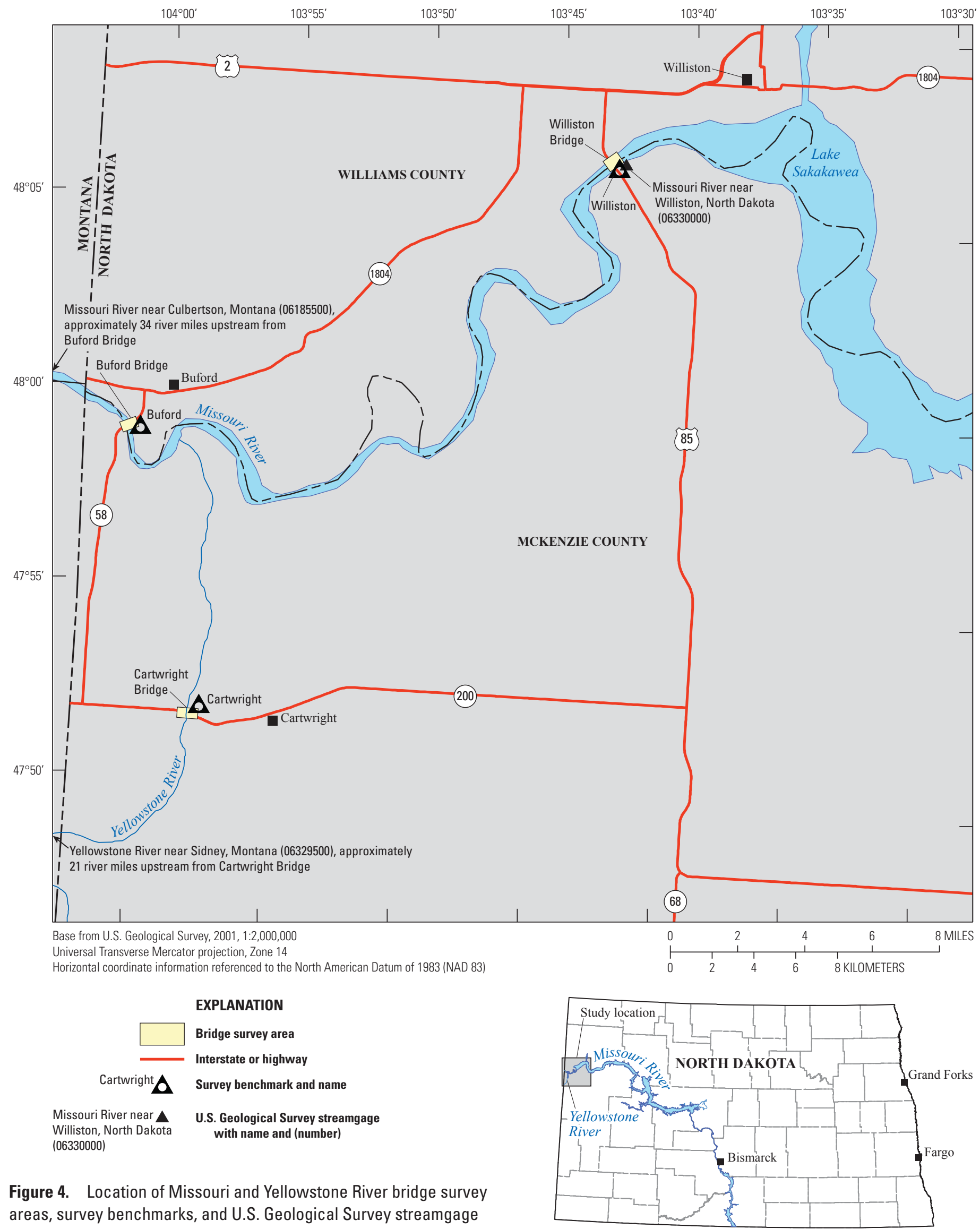
06330000 near Williston, North Dakota. 
The 18-mi survey of the Missouri River main channel through Bismarck extended from approximately the University of Mary (Sibley Bend) to Double Ditch Indian Village State historic site (fig. 2). This survey covered the main channel wherever depth was sufficient for sonar survey, typically greater than $4.5 \mathrm{ft}$. The survey was broken up into 20 sectors, each approximately 4,900 ft in length (fig. 2). This section of river varies in width from 450 to $1,770 \mathrm{ft}$. The river channel in the southern survey sectors was wide and shallow, whereas the river channel in the middle and northern survey sectors was narrower, typically ranging from 450 to $1,100 \mathrm{ft}$ in width.

The Missouri River channel is a sand-bed river through most of its length, including the stretches in North Dakota; however, the lower Yellowstone River has a gravel-framework bed, typically buried by sand. Berkas (1995) reported that the reach of the Missouri River from Garrison Dam to the headwaters of Lake Oahe had bed sediment consisting mostly of sand-sized particles. Berkas found exceptions to this just below Garrison Dam where some bed-sediment samples collected contained gravel and at one sampling location the bed consisted of bedrock. Berkas (1995) also reports that the dam and reservoir system on the Missouri River has affected the river by increasing stream width below the dam (Garrison) and increasing the streambed and bank erosion. This increased erosion likely contributes to and increases suspended-sediment load. The Missouri River system in North Dakota is controlled by dams with minimal bank protection and in-channel structures. Missouri River flow into North Dakota is controlled by Fort Peck Dam (fig. 1). Within North Dakota the main control on the river is Garrison Dam, which created Lake Sakakawea. In the free-flowing sections of river in North Dakota, channel erosion and migration occur as a result of minimal bank protection. The sediment dynamics in the free-flowing sections of the Missouri River in North Dakota are those of a sandbed stream with large effects from the upstream dams and reservoirs.

\section{Methods of Study}

Hydrographic surveys were conducted using a highresolution MBES mapping system. Although two crews in two boats collected the data, all surveys were conducted using the same high-resolution MBES mapping system and the same surveying methods. These systems and surveying methods are described in the following sections. The hydrographic survey data initially were in meters and were converted to United States survey feet (US ft).

\section{Description of Equipment}

The high-resolution MBES mapping system used during the hydrographic surveys at six Missouri River bridges, at one Yellowstone River bridge, and along $18 \mathrm{mi}$ of the Missouri River through Bismarck, N. Dak., consisted of several components, including the MBES, the inertial measurement unit (IMU) and navigation system, and a data-collection/navigation computer. Detailed descriptions of this system can be found in Huizinga and others (2010) and Huizinga (2010).

The MBES, or sonar, used on both survey boats was the RESON SeaBat ${ }^{\mathrm{TM}} 7125$ (RESON A/S, Slangerup, Denmark) operating at a frequency of 400 kilohertz $(\mathrm{kHz})$. The SeaBat ${ }^{\mathrm{TM}}$ 7125 units were operated in the equi-distance mode during the surveys. The equi-distance mode collects 512 equally spaced depth readings each time the projector sends out one sound wave (a ping), which has been transformed into beams. In this mode, the beams cover a 128 -degree $\left({ }^{\circ}\right)$ cross-track swath ${ }^{1}$ that is focused within a $1^{\circ}$ along-track area (RESON, Inc., 2006). The maximum depth that this sonar can survey is $650 \mathrm{ft}$ (table 1). The MBES consists of several components, including a projector, receiver, link-control unit (LCU), and sonar processor.

The projector and receiver were mounted on a pole on the side of the boat (fig. 5A-D). Both boats had similar mounts that rotate the sonar head to latch into a fixed position when the sonar is submerged, but the latch can be manually released to raise the sonar out of the water, or the latch can self-release if the unit is struck against an obstruction in the water (fig. 5). The mounting bracket allows for the projector and receiver to be rotated up to 20 degrees toward or away from the boat so that the sound wave is projected obliquely instead of straight down (fig. 6). The projector and receiver are each an array of piezo-electric ceramics that transform the sound wave into beams through constructive and destructive interference (fig. 6A). A sound velocity probe (RESON SVP-71) is attached to the sonar head that is submerged (fig. $6 B$ ). The speed of sound, as recorded by the sound velocity probe, is continuously monitored near the projector and receiver

${ }^{1}$ Words in bold can be found in the glossary at the end of the report.

Table 1. RESON SeaBat ${ }^{\mathrm{TM}} 7125$ specifications for the multibeam echosounder used for hydrographic surveys, 2011.

$\left[\mathrm{kHz}\right.$, kilohertz; ft, feet; ${ }^{\circ}$, degrees; $\mathrm{Hz}$, hertz; $\mathrm{CW}$, continuous wave; in., inches; $\mu$ seconds, microseconds]

\begin{tabular}{ll}
\hline Frequency & $400 \mathrm{kHz}$ \\
Maximum depth & $650 \mathrm{ft}$ \\
Swath coverage & $128^{\circ}$ \\
Beam width & $0.5^{\circ} \times 1^{\circ}$ \\
Number of beams & $256 / 512$ equi-angle or 512 equi-distant \\
Maximum update rate & $50 \mathrm{~Hz}$ \\
Wave form & Gated CW \\
Depth resolution & 0.2 in. \\
Pulse length & 33 to $300 \mu$ seconds \\
System control & $7-\mathrm{P}$ processor unit \\
Mounting angle & 20 to -20 degrees \\
\hline
\end{tabular}


arrays so depths can be accurately calculated for each sounding (RESON, Inc., 2008). If a temperature gradient is present through the water column, a profiling sound velocity probe (not shown) is used to collect a speed-of-sound profile through the water column at multiple locations in the survey area, and these data are used during data processing to correct the recorded depths.

The SeaBat ${ }^{\mathrm{TM}} 7125$ MBES is controlled by a sonar processor, a high-performance computer that manages data flow and signal attributes (power, ping rate, pulse length, gain). The sonar processor receives digitized sonar data from the LCU, receives operational settings, provides beam forming and initial processing of acoustical data, controls data formats and outputs to external systems, and receives the sound-velocity data (RESON, Inc., 2008). Software on the sonar processor provides a graphical user interface for operational settings, system control, data output, storage, and built-in test environment displays. The main system configurations controlled by the surveyor are sonar display depth range, transmit power, maximum ping rate, pulse length, and receiver gain. The display depth range controls the maximum distance that the sonar will display. Display depth range partially controls the ping rate by estimating the maximum return time for a ping. The display depth range for the RESON SeaBat ${ }^{\mathrm{TM}} 7125$ is 16.4 to $984.25 \mathrm{ft}$. During surveying, the display depth-range setting (from 5 to $90 \mathrm{ft}$ ) was changed often to correspond to the changing survey depth. The transmit power increases or decreases the amount of acoustic energy transmitted into the water. The RESON SeaBat ${ }^{\mathrm{TM}} 7125$ has an acoustic range from OFF to 220 decibels (dB). During the surveys described in this report, the power was always set at $220 \mathrm{~dB}$. Maximum ping rate limits the number of pings per second $(\mathrm{p} / \mathrm{s})$, making it lower than the standard ping rate for that range setting. The RESON SeaBat ${ }^{\mathrm{TM}} 7125$ has a ping rate from OFF to $50 \mathrm{p} / \mathrm{s}$. During surveying, ping rate is typically varied for upstream and downstream passes to collect a similar amount of data as the boat moves slowly upstream against the current and quickly downstream with the current. The ping rate was set to $10 \mathrm{p} / \mathrm{s}$ for upstream passes and $30 \mathrm{p} / \mathrm{s}$ for downstream passes. Pulse length controls the length of time the sonar signal is transmitted. Pulse length on the RESON SeaBat ${ }^{\mathrm{TM}} 7125$ can range from 10 microseconds $(\mu \mathrm{s})$ to $300 \mu \mathrm{s}$. A narrow pulse
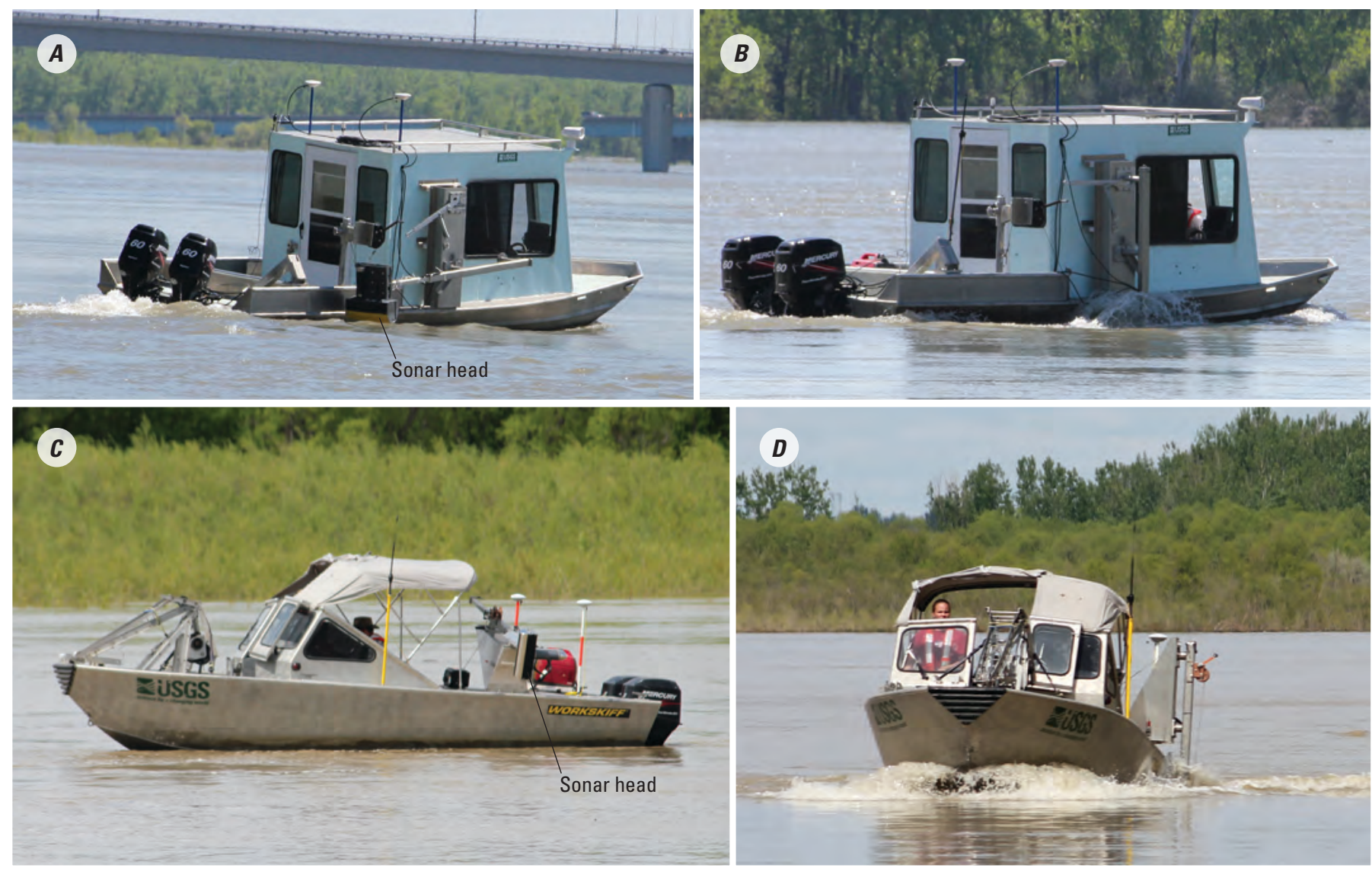

Figure 5. Hydrographic surveying using multibeam echosounder systems as installed on USGS-Nebraska boat with $(A)$ sonar head rotated out of water and $(B)$ sonar head submerged during data collection, and on USGS-Missouri boat with $(C)$ sonar head rotated out of the water and $(D)$ sonar head submerged during data collection. All photographs taken by William C. Damschen, U.S. Geological Survey (USGS): $A$ and $B$ taken June 6, 2011, and $C$ and $D$ taken June 8, 2011. 
length provides high resolution in shallow depths, but a wider pulse length provides maximum range with low-resolution images. Pulse length was typically set from $40 \mu \mathrm{s}$ to $60 \mu \mathrm{s}$ for the shallow riverine survey areas. Receiver gain controls the increase in the amplitude applied to the returned sonar signal in addition to the calculated time-varied gain (TVG). The gain settings for the RESON SeaBat ${ }^{\mathrm{TM}} 7125$ range from 0.0 to $83.0 \mathrm{~dB}$. Receiver gain was typically set for 30 to $40 \mathrm{~dB}$.

The IMU and navigation system used with the MBES on both boats was an Applanix Position Orientation Solution for Marine Vessels (POS MV ${ }^{\mathrm{TM}}$ ) WaveMaster system (Applanix Corp., Richmond Hill, Ontario, Canada). The POS MV ${ }^{\mathrm{TM}}$ system consists of two Trimble Zephyr Global Positioning System (GPS)/Global Navigation Satellite System (GNSS) antennas (Trimble Navigation, Ltd., Sunnyvale, Calif.), the IMU, and a POS computer system that is configured and monitored through MV-POS View Controller. The MV-POS View Controller is operated using the sonar processor. The IMU consists of three linear accelerometers and three solidstate gyroscopes arranged in a triaxial orthogonal array to sense acceleration and angular motion in all three axes. The POS MV ${ }^{\mathrm{TM}}$ system provides position, roll and pitch angle, true heading, and real-time heave of the boat to correct the MBES data. In addition to the dual GPS/GNSS antennas and the IMU, the POS MV ${ }^{\mathrm{TM}}$ system has the capability of utilizing Real-Time Kinematic (RTK) GPS/GNSS correction information. The POS MV ${ }^{\mathrm{TM}}$ GPS/GNSS azimuth Measurement
Subsystem and RTK solution were used during the survey, so the accuracy of the roll and pitch measured was $0.02^{\circ}$, heave was $0.164 \mathrm{ft}$, heading was $0.06^{\circ}$, position was 0.06 to $0.30 \mathrm{ft}$, and velocity was 0.164 feet per second (ft/s) (Applanix Corporation, 2006). The POS MV ${ }^{\mathrm{TM}}$ system measured boat position and motion accurately during short GPS/GNSS outages, which occurred near shorelines and under bridges.

All the sounding and motion data were combined, saved, and displayed using the HYPACK ${ }^{\circledR} / \mathrm{HYSWEEP}{ }^{\circledR}$ software (HYPACK, Inc., 2007a and 2007b) that was running on either a separate desktop computer or on the sonar processor in the field during data collection. The HYPACK ${ }^{\circledR} /$ HYSWEEP ${ }^{\circledR}$ software allowed the surveyor and boat pilot to view the collected data for evaluation and navigation, respectively. Orthophotographs and other background data were loaded into the HYPACK ${ }^{\circledR} / \mathrm{HYSWEEP}{ }^{\circledR}$ software for geographical reference. In addition, survey lines and designated survey areas were drawn in HYPACK $\AA / H Y S W E E P \AA$ software for additional navigation, and targets of locations-of-interest were collected throughout the survey.

The high-resolution MBES system used for hydrographic surveys described in this report was able to produce highquality data only when all of the components operated seamlessly together. The positions of each sensor were precisely known in relation to all others, calibrations were completed to determine the exact position of the projector and receiver as it was mounted, timing between all computers precisely
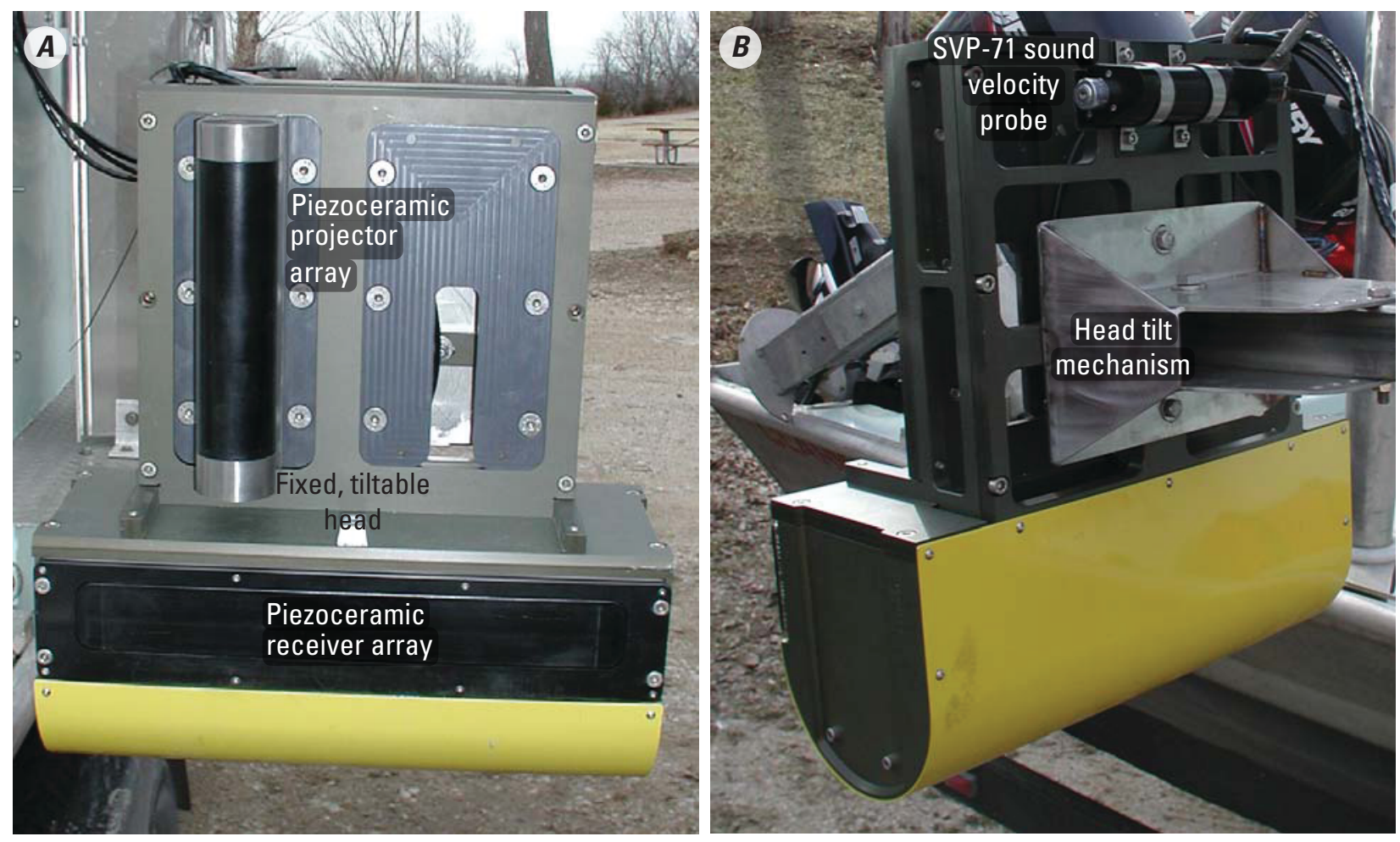

Figure 6. RESON SeaBat ${ }^{\mathrm{TM}} 7125$ multibeam echosounder components that are submerged during data collection, shown as $(A)$ bottom view and $(B)$ top oblique view. (From Huizinga and others, 2010). 
agreed, and the surveyor ensured that all settings were correct and adequate for the survey environment and that all data were being transferred, utilized, and stored correctly. A schematic diagram (fig. 7) shows the MBES system components and the manner in which each component was linked to produce the final survey data.

\section{Survey Methods}

The same procedures were used to survey each study area, as well as process each dataset. The MBES was set up on each boat in a standard sensor configuration and surveyed using a total station, which is an electronic transit or a laser surveying instrument, to determine the inter-sensor offsets.

\section{Field Procedures}

The first step in conducting each MBES hydrographic survey was to establish a GPS base station to provide GPS/ GNSS positional correction information to the survey boat during data collection. If a pre-existing, high-accuracy [elevation, orthometric height, or ellipsoid height published by the National Geodetic Survey (NGS) or other trusted organization to the nearest millimeter] survey benchmark was not in close proximity to the survey area, a new USGS benchmark was set. A GPS/GNSS base station was then established over the previously known or newly set benchmark. The first surveys of all bridges were conducted using a base station set up over a newly set benchmark using estimated coordinates. The satellite data logged by the base receiver were post-processed through the NGS Online Positioning Users Service (OPUS) to determine survey-grade coordinates for the benchmark after the hydrographic surveying was complete. Once the benchmark data were post-processed, an offset from the estimated coordinates to the survey-grade coordinates was calculated so that the hydrographic dataset from that survey site could be corrected. The second survey at each bridge site was then conducted with the base station again set up on the newly established benchmark, but using the OPUS-derived coordinates, so no offset adjustment to the dataset was needed during data processing. Similarly, the newly established benchmarks and the pre-existing NGS benchmark were used during the survey of $18 \mathrm{mi}$ of river through the Bismarck reach, which had known coordinates prior to that surveying, so no offset correction was needed during data processing.

The surveyor typically configured the survey details by using HYPACK ${ } /$ HYSWEEP ${ }^{\circledR}$ software, including selection of geodetic coordinate information, survey units, software drivers to allow communication with all components, and survey matrix delineating the survey area. The survey area at each bridge site extended $820 \mathrm{ft}$ upstream from the bridge to $820 \mathrm{ft}$ downstream from the bridge. The survey area for the 18-mi reach was divided into 20 sectors, each $4,900 \mathrm{ft}$ in length.

During a typical survey, there was a crew of two aboard the boat: one piloted the boat while the surveyor operated the sonar unit. The sonar operator (surveyor) adjusted the settings as necessary to maintain data quality during collection at each particular survey location. The sonar operator also recorded notes of file names, survey locations, tide accuracy, and other information that would be useful for data processing, such as underwater structures detected and sounding quality. The sonar operator also evaluated all the positioning and motion data being collected to ensure that the sonar data could later be accurately corrected. The pilot monitored the chart display showing the boat's location within the survey area and the data being collected. The chart view allowed the pilot to navigate to areas that had not been surveyed and to ensure that data overlapped between passes. In this fashion, the pilot ensured that there was full bed coverage to the extent that time and water depth allowed.

If the surveyor determined that the positioning data collected were not adequate to accurately determine the watersurface elevation, then additional water-surface elevation information was collected using a GPS/GNSS unit independent of those units used by the boat navigation system. This GPS/GNSS unit received, by radio, the base-station correction information to accurately correct the satellite-relayed information and determine a water-surface elevation. These elevation data were then applied during post-processing, as needed.

During the hydrographic surveys, additional data were collected to calibrate the mounting position of the MBES unit, and that procedure is described below in the "Quality Assurance/Quality Control" section of this report. At the end of each day of surveying, the data collected in HYPACK ${ }^{\circledR} /$ HYSWEEP ${ }^{\circledR}$ software were saved from the boat computers onto an external hard drive for backup.

\section{Data-Processing Procedures}

Processing of MBES data required several steps and software that is capable of working with large datasets. The USGS used three different software packages to process multibeam data: HYPACK $® / H Y S W E E P ® ~ s o f t w a r e$, CARIS HIPS and SIP $^{\mathrm{TM}}$ and Bathy DataBASE: Base Editor ${ }^{\mathrm{TM}}$ software (CARIS, 2012a and 2012b), and Esri's ArcMap software (Esri, 2012b).

Prior to editing the data, all offset values and calibration values were either determined or evaluated, and the values were applied to the dataset before it was finalized. Calibration values were determined from processing data collected specifically for the calibration test. This process is described in the "Quality Assurance/Quality Control" section of this report. Offset values were determined for each boat's set up and did not change as long as mounting points remained unaltered; however, the surveyor is required to verify that all offsets were entered correctly for each dataset. 


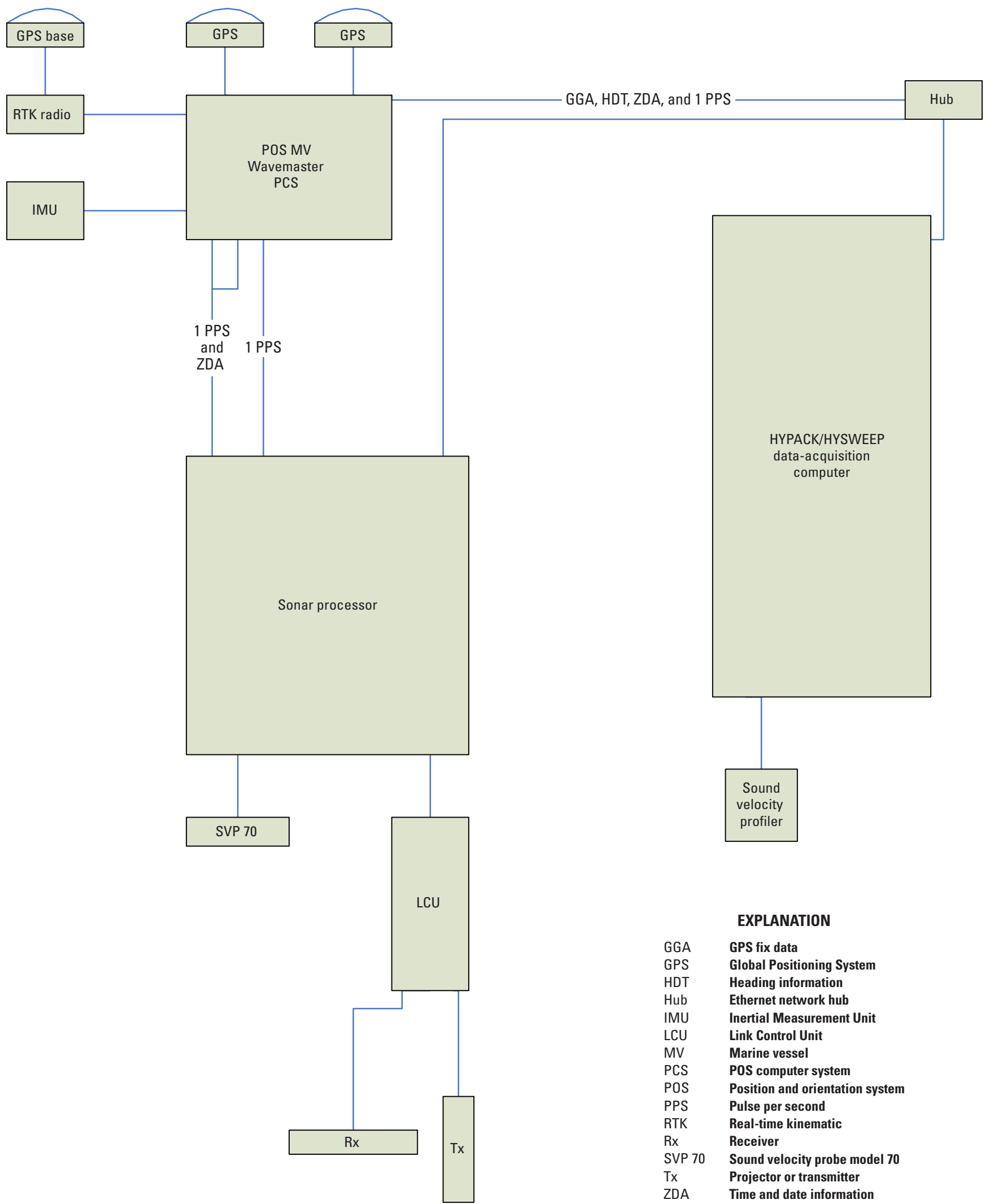

Figure 7. High-resolution multibeam echosounder system components (from RESON, Inc., written commun., 2007). 
Next, water-surface (or tide) values were reviewed to ensure that accurate corrections were applied to the depth measurements to calculate riverbed elevation. If water-surface elevations were not accurate enough (determined by having a fixed GPS/GNSS solution) throughout the dataset, then manual tides were applied by creating tide files. One tide file was created for the upstream survey extent per sector, also called a matrix, per day, and one tide file was created for the downstream survey extent per sector or matrix per day. Upstream and downstream tide files were used together by the processing software to calculate tide values for the entire matrix. Tide files can also incorporate change of tide throughout the day if necessary. The values used in these tide files were either water-surface elevations, as determined by a GPS/ GNSS unit independent of the unit used for boat navigation, or the upstream and downstream averages of the elevation data collected by the boat's navigation system that met the accuracy requirements (had fixed GPS/GNSS solutions).

After tide-correction values were determined and applied to the dataset, filters were applied to remove some of the erroneous data points from the hydrographic dataset. Filters removed some data points that did not agree within $0.03 \mathrm{ft}$ with nearby data points. Data points flagged as low-quality because they were collected at low signal strength and (or) because they were not collinear in elevation/depth were removed. Data points from the extreme outside beams of the swath were removed as well. Data from outside beams were removed because they are typically very noisy; when data coverage is sufficient, removal of these data will not affect the completeness of the survey. After filters were applied, each swath (width of a single passage or $128^{\circ}$, made up of many sonar pings with each ping containing 512 soundings) was evaluated manually to ensure that all outliers had been removed and that all data were deemed corrected.

The corrected data then were rasterized and exported in small sections. A grid with 1.64-ft-by-1.64-ft cells that covered the survey area was used to reduce the dataset by averaging all data points within a cell so that the average bed elevation associated with the center of each grid cell was exported. The full point-dataset was typically very large and difficult to work with in many software programs, so dataset reduction was typically necessary. On the smaller survey sections, such as those at bridge sites, this initial data export was the final $x-y-z$ dataset. However, on the larger survey sections of the 18-mi reach, a second gridding step was necessary because the size of the dataset reduced with 1.64-ft-by-1.64-ft cells was too large to export as one continuous grid and to ensure a seamless edge match between all exported sections. Therefore, once all sections of large survey areas had been exported from HYPACK ${ }^{\circledR} / \mathrm{HYSWEEP}{ }^{\circledR}$ software using grids with $1.64-\mathrm{ft}$ cells, they were all gridded a second time to produce a final 3.28-ft cell x-y-z dataset. CARIS Bathy DataBASE: Base Editor $^{\mathrm{TM}}$ software was used to open the multiple reduced datasets from HYPACK ${ }^{\circledR} / \mathrm{HYSWEEP}{ }^{\circledR}$ software and create the final 3.28-ft cell $\mathrm{x}-\mathrm{y}-\mathrm{z}$ data by calculating a mean-distance weighted average for each cell.

Once the $x-y-z$ datasets were exported, those surveys that were collected with coordinates referenced to an autonomous or unknown benchmark position needed to have an offset correction applied; the correction was based on the final benchmark coordinates as calculated using OPUS from NGS. To process the GPS/GNSS data collected at unknown benchmarks, the data files collected by the receiver were downloaded, the proprietary files were converted to RINEX (Receiver Independent Exchange) format, and the RINEX files were submitted to OPUS through an online utility (National Geodetic Survey, 2012a). The submitted data were processed by NGS using reference data from Continuously Operating Reference Stations (CORS) (National Geodetic Survey, 2012b) to determine a corrected position for the newly established benchmark. The report returned by NGS included error estimates and other information useful for evaluating the quality of the final coordinates determined. The offset between the autonomous base-station position assumed during surveying and the final coordinates for the benchmark was calculated, and the $x-y-z$ data were adjusted accordingly, resulting in final corrected $x-y-z$ datasets.

The final steps in data processing included conversion from meter to U.S. survey feet, evaluation of data using Esri's ArcMap software, creation of files that allow the user to easily view the large datasets, and creation of metadata for each file. CARIS Bathy DataBASE: Base Editor ${ }^{\mathrm{TM}}$ software was used to create CARIS Spatial Archive ${ }^{\mathrm{TM}}$ (CSAR ${ }^{\mathrm{TM}}$ ) format files that can be opened with public-domain software and that allow for easy two-dimensional (2-D) and three-dimensional (3-D) viewing of large datasets. Metavist software (Rugg, 2004) was used to create the metadata containing documentation of the methods, cartographic projection, and other important information about each dataset.

\section{Quality Assurance/Quality Control}

Two primary methods were used for quality assurance and quality control $(\mathrm{QA} / \mathrm{QC})$ during collection and processing of data with the MBES system: operator QA/QC during collection and patch tests. During collection of hydrographic data, the sonar operator was continuously checking the data being logged for poor soundings (such as those that had low intensity or were not collinear with the surrounding data) and adjusting settings on the system to ensure the best possible data were collected. The surveyor also compared the data collected in overlapping sections to ensure that the data being collected were similar to those from previous passes.

Patch tests are short survey transects or lines located in specifically selected areas and surveyed, in certain directions, to determine orientation and timing offsets of the MBES with respect to the IMU. Survey data were collected in HYPACK ${ }^{\circledR} /$ HYSWEEP ${ }^{\circledR}$ software as normal, but data from these 
specific survey transects or lines were further evaluated using HYPACK ${ }^{\circledR} / \mathrm{HYSWEEP}{ }^{\circledR}$ software to determine latency and offset values. Patch tests were used to determine the latency or timing difference between the MBES and the POS MV ${ }^{\mathrm{TM}}$ positioning data. In addition, patch tests were used to determine the angular offsets of the MBES projector/receiver with respect to the IMU. These angular offsets are referred to as roll, pitch, and yaw. Uncorrected latency, pitch, and yaw offsets appear as horizontal offsets in the collected data, whereas an uncorrected roll offset appears as vertical and horizontal offsets in the data.

The latency test was used to determine a timing offset $(\Delta \mathrm{t})$ between the MBES system and the positioning or GPS component of the POS MV ${ }^{\mathrm{TM}}$ as shown in figure $8 A$. Timing offsets were determined by collecting data on the same line over a slope or feature in the same direction, but at two different speeds: fast and slow. The latency test performed for this survey found that the latency was zero for the collected data from both survey boats $(\Delta \mathrm{t}=0)$.

A roll test was used to determine the angular offset of the MBES projector/receiver alignment with respect to the IMU orientation along the longitudinal axis of the boat. This angle is shown in figure $8 B$ as $\alpha$. To determine the roll-angle offset, $\alpha$, data were collected over a flat area on one line; data were collected twice while the boat moved in opposite directions. The roll test performed for this survey found that the roll angle offset $(\alpha)$ was equal to $-19.6^{\circ}$ for the Nebraska survey boat, which is expected because the projector/receiver was intentionally rolled at approximately $-20^{\circ}$. The roll test for the Missouri survey boat found the roll angle offset $(\alpha)$ was equal to $-0.1^{\circ}$ before the mount was bent from hitting a submerged $\log$ and $-2.8^{\circ}$ after.

The pitch test was used to determine the angular offset of the MBES transducer projector/receiver alignment with respect to the IMU orientation in the lateral axis or along the track direction of the boat. The pitch-offset angle is shown as angle $\beta$ in figure $8 C$. To determine the pitch-angle offset, $\beta$, one line was surveyed twice over a slope or feature; data were collected twice while the boat moved in opposite directions. The pitch test performed for this survey found that the pitch angle offset $(\beta)$ was equal to $-3^{\circ}$ for the Nebraska survey boat and $2.5^{\circ}$ both before hitting the submerged log and after for the Missouri survey boat.

The yaw test was used to determine the angular offset of the MBES projector/receiver alignment with respect to the IMU orientation about the vertical axis. The yaw-offset angle is shown as angle $\delta$ in figure $8 D$. To determine the yaw-angle offset, $\delta$, two lines were collected parallel to each other while the boat moved in the same direction over a slope or feature. The yaw test performed for this survey found that the yaw angle offset ( $\delta$ ) was equal to $3.5^{\circ}$ for the Nebraska survey boat and $3.3^{\circ}$ both before hitting the submerged log and after for the Missouri survey boat.

Overall accuracy of the hydrographic data presented in this report is estimated to be $\pm 0.7 \mathrm{ft}$. This estimate is based on equipment specifications, evaluation of overlap data, and previous data collection with this equipment. Accuracy of hydrographic survey data is typically challenging to evaluate since there are limited underwater areas with known elevation. However, the quality of hydrographic surveys is often described by uncertainty estimates called Total Propagated Uncertainty (TPU) (CARIS, 2011). A TPU calculation was not completed for these hydrographic survey data because the workflow, which included both HYPACK ${ }^{\circledR} / \mathrm{HYSWEEP}{ }^{\circledR}$ software and CARIS Bathy DataBASE: Base Editor ${ }^{\mathrm{TM}}$ software, was not compatible with efficiently calculating TPU.

\section{Hydrographic Surveys on the Missouri and Yellowstone Rivers at Selected Bridges}

The initial surveys of six Missouri River bridges and one Yellowstone River bridge were conducted during June 6-9, 2011 (table 2). The upstream and downstream extent of each survey area, approximately 1,640 ft in total length, was summarized by mid-channel point location (table 2). The three Missouri River bridges in Bismarck were surveyed a second time as part of the 18-mi Bismarck-reach survey during June 28-July 8, 2011, and a resurvey of the Washburn Bridge was completed on July 9, 2011 (table 2).

The benchmarks used to georeference these bridge surveys, both newly established and NGS benchmarks, are listed in table 3. Data collected by the base receiver each survey day was processed through NGS OPUS, either to establish highquality coordinates at a newly established benchmark (referred to as an "OPUS Primary" benchmark type in table 3) or as a quality-assurance check (referred to as an "OPUS Check" in table 3). Most locations from OPUS checks matched the published or established horizontal coordinates accurately; however, some of the elevation checks did not. All the OPUS checks made on the NGS published benchmark designated Sibley 2 (NGS permanent identifier AE1790; National Geodetic Survey, 2012c) varied by an average of $0.2 \mathrm{ft}$ in ellipsoid height and $0.4 \mathrm{ft}$ in orthometric height. The orthometric height value of Sibley 2 was published using precision to one-tenth meter ( $568.0 \mathrm{~m}$ or 1,864 ft); however, the ellipsoid height was published by NGS with much higher precision (546.433 meters or 1,792.756 ft), so the ellipsoid height was used for the survey. The OPUS check on Bismarck Gage Water Cover benchmark (fig. 2) on July 3, 2011, differed from the primary coordinates by a little more than $0.2 \mathrm{ft}$ in both the ellipsoid and the orthometric height from the OPUS Primary heights surveyed July 2, 2011. There are two OPUS Primary coordinates listed in table 3 for Bismarck Gage Water Cover because when surveyed June 6, 2011, the exact benchmark location was not physically marked, only described by the surveyor. When surveyed during July, a different survey crew 
used the benchmark but could not be certain that the benchmark used was exactly the same point as that used previously; therefore, new coordinates were established. All other OPUS checks, excluding the two times when data were collected for a short time span or at the incorrect time interval, differed by less than $0.2 \mathrm{ft}$ from the OPUS primary or published coordinates (table 3 ).

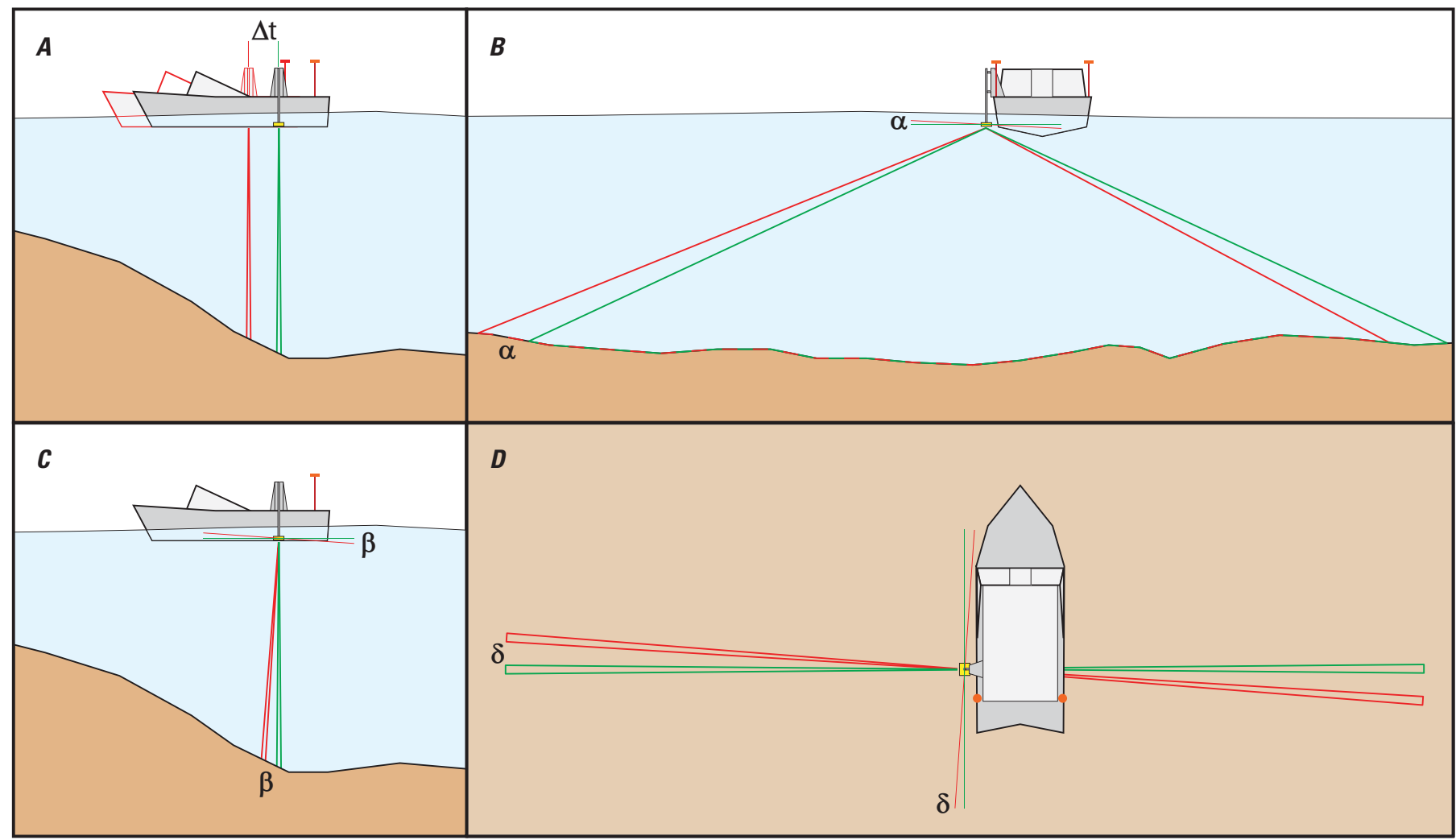

\section{EXPLANATION}

Sounding to actual bottom

Sounding to measured bottom

$\Delta t \quad$ Timing offset for latency between the multibeam echosounder and Global

Positioning System components of the navigation and motion-sensing system

$\alpha \quad$ Angular offset for roll of the transducer head along the longitudinal axis of the boat

$\beta \quad$ Angular offset for pitch of the transducer head along the lateral axis of the boat

$\delta \quad$ Angular offset for yaw of the transducer head about the vertical axis

Figure 8. Effects of $(A)$ timing offset for latency, and angular offsets for $(B)$ roll, $(C)$ pitch, and $(D)$ yaw on data from a multibeam echosounder (from Huizinga, 2011). 
Table 2. Dates and locations of hydrographic surveys at bridge sites and sections on the Missouri and Yellowstone Rivers, North Dakota, during the 2011 flood.

[US, upstream; DS, downstream; ND, North Dakota; Hwy, Highway; ', degree; ', minute; ", second; N, north; W, west]

\begin{tabular}{|c|c|c|c|c|c|}
\hline \multirow{2}{*}{ Site } & \multirow{2}{*}{ Survey date } & \multicolumn{2}{|c|}{ US middle of channel } & \multicolumn{2}{|c|}{ DS middle of channel } \\
\hline & & Latitude & Longitude & Latitude & Longitude \\
\hline West Bismarck Expressway Bridge (ND Hwy 810) & $6 / 6 / 2011$ & $46^{\circ} 47^{\prime} 53.4836^{\prime \prime} \mathrm{N}$ & $100^{\circ} 49^{\prime} 11.6147^{\prime \prime} \mathrm{W}$ & $46^{\circ} 47^{\prime} 36.4934^{\prime \prime} \mathrm{N}$ & $100^{\circ} 49^{\prime} 10.5285^{\prime \prime} \mathrm{W}$ \\
\hline Grant Marsh Bridge (I-94) & 6/6/2011 & $46^{\circ} 49^{\prime} 28.4834^{\prime \prime} \mathrm{N}$ & $100^{\circ} 49^{\prime} 52.7656^{\prime \prime} \mathrm{W}$ & $46^{\circ} 49^{\prime} 16.982^{\prime \prime} \mathrm{N}$ & $100^{\circ} 49^{\prime} 44.573^{\prime \prime} \mathrm{W}$ \\
\hline Memorial Highway Bridge (Business Loop I-94) & $6 / 7 / 2011$ & $46^{\circ} 48^{\prime} 35.7062^{\prime \prime} \mathrm{N}$ & $100^{\circ} 49^{\prime} 13.5328^{\prime \prime} \mathrm{W}$ & $46^{\circ} 48^{\prime} 15.6713^{\prime \prime} \mathrm{N}$ & $100^{\circ} 49^{\prime} 08.7349^{\prime \prime} \mathrm{W}$ \\
\hline Cartwright Bridge (ND Hwy 200, Yellowstone River) & $6 / 8 / 2011$ & $47^{\circ} 51^{\prime} 33.6619^{\prime \prime} \mathrm{N}$ & $103^{\circ} 58^{\prime} 01.2039^{\prime \prime} \mathrm{W}$ & $47^{\circ} 51^{\prime} 51.1388^{\prime \prime} \mathrm{N}$ & $103^{\circ} 57^{\prime} 59.0732^{\prime \prime} \mathrm{W}$ \\
\hline Buford Bridge (ND Hwy 58) & $6 / 8 / 2011$ & $47^{\circ} 59^{\prime} 08.83^{\prime \prime} \mathrm{N}$ & $104^{\circ} 01^{\prime} 03.1515^{\prime \prime} \mathrm{W}$ & $47^{\circ} 58^{\prime} 53.6394^{\prime \prime} \mathrm{N}$ & $104^{\circ} 00^{\prime} 51.1184^{\prime \prime} \mathrm{W}$ \\
\hline Williston Bridge (U.S. Hwy 85) & $6 / 8 / 2011$ & $48^{\circ} 06^{\prime} 27.4485^{\prime \prime} \mathrm{N}$ & $103^{\circ} 43^{\prime} 07.8039^{\prime \prime} \mathrm{W}$ & $48^{\circ} 06^{\prime} 41.2863^{\prime \prime} \mathrm{N}$ & $103^{\circ} 42^{\prime} 45.8019^{\prime \prime} \mathrm{W}$ \\
\hline Washburn Bridge (ND Hwy 200) & $6 / 9 / 2011$ & $47^{\circ} 17^{\prime} 23.5024^{\prime \prime} \mathrm{N}$ & $101^{\circ} 02^{\prime} 46.9623^{\prime \prime} \mathrm{W}$ & $47^{\circ} 17^{\prime} 14.2378^{\prime \prime} \mathrm{N}$ & $101^{\circ} 02^{\prime} 20.5875^{\prime \prime} \mathrm{W}$ \\
\hline Sector 1 & $6 / 28 / 2011$ & $46^{\circ} 44^{\prime} 06.9861^{\prime \prime} \mathrm{N}$ & $100^{\circ} 47^{\prime} 02.3006^{\prime \prime} \mathrm{W}$ & $46^{\circ} 43^{\prime} 26.3691^{\prime \prime} \mathrm{N}$ & $100^{\circ} 46^{\prime} 19.4042^{\prime \prime} \mathrm{W}$ \\
\hline Sector 2 & $7 / 2 / 2011$ & $46^{\circ} 44^{\prime} 07.4763^{\prime \prime} \mathrm{N}$ & $100^{\circ} 48^{\prime} 10.3257^{\prime \prime} \mathrm{W}$ & $46^{\circ} 44^{\prime} 06.9861^{\prime \prime} \mathrm{N}$ & $100^{\circ} 47^{\prime} 02.3006^{\prime \prime} \mathrm{W}$ \\
\hline Sector 3 & $7 / 1 / 2011$ & $46^{\circ} 44^{\prime} 24.0951^{\prime \prime} \mathrm{N}$ & $100^{\circ} 49^{\prime} 01.7078^{\prime \prime} \mathrm{W}$ & $46^{\circ} 44^{\prime} 07.4763^{\prime \prime} \mathrm{N}$ & $100^{\circ} 48^{\prime} 10.3257^{\prime \prime} \mathrm{W}$ \\
\hline Sector 4 & $6 / 29 / 2011,7 / 1 / 2011$ & $46^{\circ} 44^{\prime} 48.8894^{\prime \prime} \mathrm{N}$ & $100^{\circ} 49^{\prime} 52.8715^{\prime \prime} \mathrm{W}$ & $46^{\circ} 44^{\prime} 24.0951^{\prime \prime} \mathrm{N}$ & $100^{\circ} 49^{\prime} 01.7078^{\prime \prime} \mathrm{W}$ \\
\hline Sector 5 & $6 / 29 / 2011$ & $46^{\circ} 45^{\prime} 30.1802^{\prime \prime} \mathrm{N}$ & $100^{\circ} 50^{\prime} 16.4459^{\prime \prime} \mathrm{W}$ & $46^{\circ} 44^{\prime} 48.8894^{\prime \prime} \mathrm{N}$ & $100^{\circ} 49^{\prime} 52.8715^{\prime \prime} \mathrm{W}$ \\
\hline Sector 6 & $6 / 29 / 2011$ & $46^{\circ} 46^{\prime} 18.2191^{\prime \prime} \mathrm{N}$ & $100^{\circ} 50^{\prime} 04.4923^{\prime \prime} \mathrm{W}$ & $46^{\circ} 45^{\prime} 30.1802^{\prime \prime} \mathrm{N}$ & $100^{\circ} 50^{\prime} 16.4459^{\prime \prime} \mathrm{W}$ \\
\hline Sector 7 & $7 / 3 / 2011$ & $46^{\circ} 46^{\prime} 55.4463^{\prime \prime} \mathrm{N}$ & $100^{\circ} 49^{\prime} 26.3185^{\prime \prime} \mathrm{W}$ & $46^{\circ} 46^{\prime} 18.2191^{\prime \prime} \mathrm{N}$ & $100^{\circ} 50^{\prime} 04.4923^{\prime \prime} \mathrm{W}$ \\
\hline Sector 8 & $7 / 3 / 2011$ & $46^{\circ} 47^{\prime} 39.0106^{\prime \prime} \mathrm{N}$ & $100^{\circ} 49^{\prime} 12.6774^{\prime \prime} \mathrm{W}$ & $46^{\circ} 46^{\prime} 55.4463^{\prime \prime} \mathrm{N}$ & $100^{\circ} 49^{\prime} 26.3185^{\prime \prime} \mathrm{W}$ \\
\hline Sector 9/Memorial Highway/West Bismarck Expressway Bridges & $7 / 3 / 2011$ & $46^{\circ} 48^{\prime} 35.3241^{\prime \prime} \mathrm{N}$ & $100^{\circ} 49^{\prime} 14.7215^{\prime \prime} \mathrm{W}$ & $46^{\circ} 47^{\prime} 39.0106^{\prime \prime} \mathrm{N}$ & $100^{\circ} 49^{\prime} 12.6774^{\prime \prime} \mathrm{W}$ \\
\hline Sector 10 & $7 / 2 / 2011$ & $46^{\circ} 49^{\prime} 17.1212^{\prime \prime} \mathrm{N}$ & $100^{\circ} 49^{\prime} 43.7106^{\prime \prime} \mathrm{W}$ & $46^{\circ} 48^{\prime} 35.3241^{\prime \prime} \mathrm{N}$ & $100^{\circ} 49^{\prime} 14.7215^{\prime \prime} \mathrm{W}$ \\
\hline Sector 11/Grant Marsh Bridge (I-94) & $7 / 5 / 2011$ & $46^{\circ} 49^{\prime} 40.6001^{\prime \prime} \mathrm{N}$ & $100^{\circ} 50^{\prime} 42.1176^{\prime \prime} \mathrm{W}$ & $46^{\circ} 49^{\prime} 17.1212^{\prime \prime} \mathrm{N}$ & $100^{\circ} 49^{\prime} 43.7106^{\prime \prime} \mathrm{W}$ \\
\hline Sector 12 & $7 / 5 / 2011$ & $46^{\circ} 50^{\prime} 07.2905^{\prime \prime} \mathrm{N}$ & $100^{\circ} 51^{\prime} 41.2408^{\prime \prime} \mathrm{W}$ & $46^{\circ} 49^{\prime} 40.6001^{\prime \prime} \mathrm{N}$ & $100^{\circ} 50^{\prime} 42.1176^{\prime \prime} \mathrm{W}$ \\
\hline Sector 13 & $7 / 6 / 2011$ & $46^{\circ} 50^{\prime} 50.7756^{\prime \prime} \mathrm{N}$ & $100^{\circ} 52^{\prime} 06.9148^{\prime \prime} \mathrm{W}$ & $46^{\circ} 50^{\prime} 07.2905^{\prime \prime} \mathrm{N}$ & $100^{\circ} 51^{\prime} 41.2408^{\prime \prime} \mathrm{W}$ \\
\hline Sector 14 & $7 / 6 / 2011$ & $46^{\circ} 51^{\prime} 37.5318^{\prime \prime} \mathrm{N}$ & $100^{\circ} 52^{\prime} 22.4344^{\prime \prime} \mathrm{W}$ & $46^{\circ} 50^{\prime} 50.7756^{\prime \prime} \mathrm{N}$ & $100^{\circ} 52^{\prime} 06.9148^{\prime \prime} \mathrm{W}$ \\
\hline Sector 15 & 7/6/2011, 7/7/2011 & $46^{\circ} 52^{\prime} 19.2263^{\prime \prime} \mathrm{N}$ & $100^{\circ} 52^{\prime} 52.8558^{\prime \prime} \mathrm{W}$ & $46^{\circ} 51^{\prime} 37.5318^{\prime \prime} \mathrm{N}$ & $100^{\circ} 52^{\prime} 22.4344^{\prime \prime} \mathrm{W}$ \\
\hline Sector 16 & $7 / 7 / 2011$ & $46^{\circ} 53^{\prime} 02.0841^{\prime \prime} \mathrm{N}$ & $100^{\circ} 53^{\prime} 25.3534^{\prime \prime} \mathrm{W}$ & $46^{\circ} 52^{\prime} 19.2263^{\prime \prime} \mathrm{N}$ & $100^{\circ} 52^{\prime} 52.8558^{\prime \prime} \mathrm{W}$ \\
\hline Sector 17 & 7/7/2011 & $46^{\circ} 53^{\prime} 42.1163^{\prime \prime} \mathrm{N}$ & $100^{\circ} 54^{\prime} 02.7547^{\prime \prime} \mathrm{W}$ & $46^{\circ} 53^{\prime} 02.0841^{\prime \prime} \mathrm{N}$ & $100^{\circ} 53^{\prime} 25.3534^{\prime \prime} \mathrm{W}$ \\
\hline Sector 18 & $7 / 8 / 2011$ & $46^{\circ} 54^{\prime} 27.0608^{\prime \prime} \mathrm{N}$ & $100^{\circ} 54^{\prime} 07.9567^{\prime \prime} \mathrm{W}$ & $46^{\circ} 53^{\prime} 42.1163^{\prime \prime} \mathrm{N}$ & $100^{\circ} 54^{\prime} 02.7547^{\prime \prime} \mathrm{W}$ \\
\hline Sector 19 & $7 / 8 / 2011$ & $46^{\circ} 55^{\prime} 12.4198^{\prime \prime} \mathrm{N}$ & $100^{\circ} 53^{\prime} 47.3296^{\prime \prime} \mathrm{W}$ & $46^{\circ} 54^{\prime} 27.0608^{\prime \prime} \mathrm{N}$ & $100^{\circ} 54^{\prime} 07.9567^{\prime \prime} \mathrm{W}$ \\
\hline Sector 20 & $7 / 8 / 2011$ & $46^{\circ} 55^{\prime} 55.6819^{\prime \prime} \mathrm{N}$ & $100^{\circ} 54^{\prime} 12.9143^{\prime \prime} \mathrm{W}$ & $46^{\circ} 55^{\prime} 12.4198^{\prime \prime} \mathrm{N}$ & $100^{\circ} 53^{\prime} 47.3296^{\prime \prime} \mathrm{W}$ \\
\hline Washburn Bridge (ND Hwy 200) & 7/9/2011 & $47^{\circ} 17^{\prime} 23.5024^{\prime \prime} \mathrm{N}$ & $101^{\circ} 02^{\prime} 46.9623^{\prime \prime} \mathrm{W}$ & $47^{\circ} 17^{\prime} 14.2378^{\prime \prime} \mathrm{N}$ & $101^{\circ} 02^{\prime} 20.5875^{\prime \prime} \mathrm{W}$ \\
\hline
\end{tabular}


Table 3. Location and location checks of benchmarks used for hydrographic surveys of the Missouri and Yellowstone Rivers, North Dakota, during the 2011 flood.

[NAD 83 (CORS96), North American Datum 1983 CORS 96 adjustment; UTM, Universal Transverse Mercator; us ft, U.S. survey feet; GRS 80, Geodetic Reference System 1980; NAVD 88, North American Vertical Datum of 1988; Geoid09, model for transforming heights between ellisoidal coordinates and NAVD 88 orthometric heights; OPUS, Online Positioning User Service; OPUS Primary, is the OPUS solution used as the true location of the benchmark; OPUS Check, is the OPUS solution derived from data collected on the benchmark and used to verify accuracy of base-station data collection, --, no data; NGS, National Geodetic Survey; AE1790, National Geodetic Survey permanent identifier]

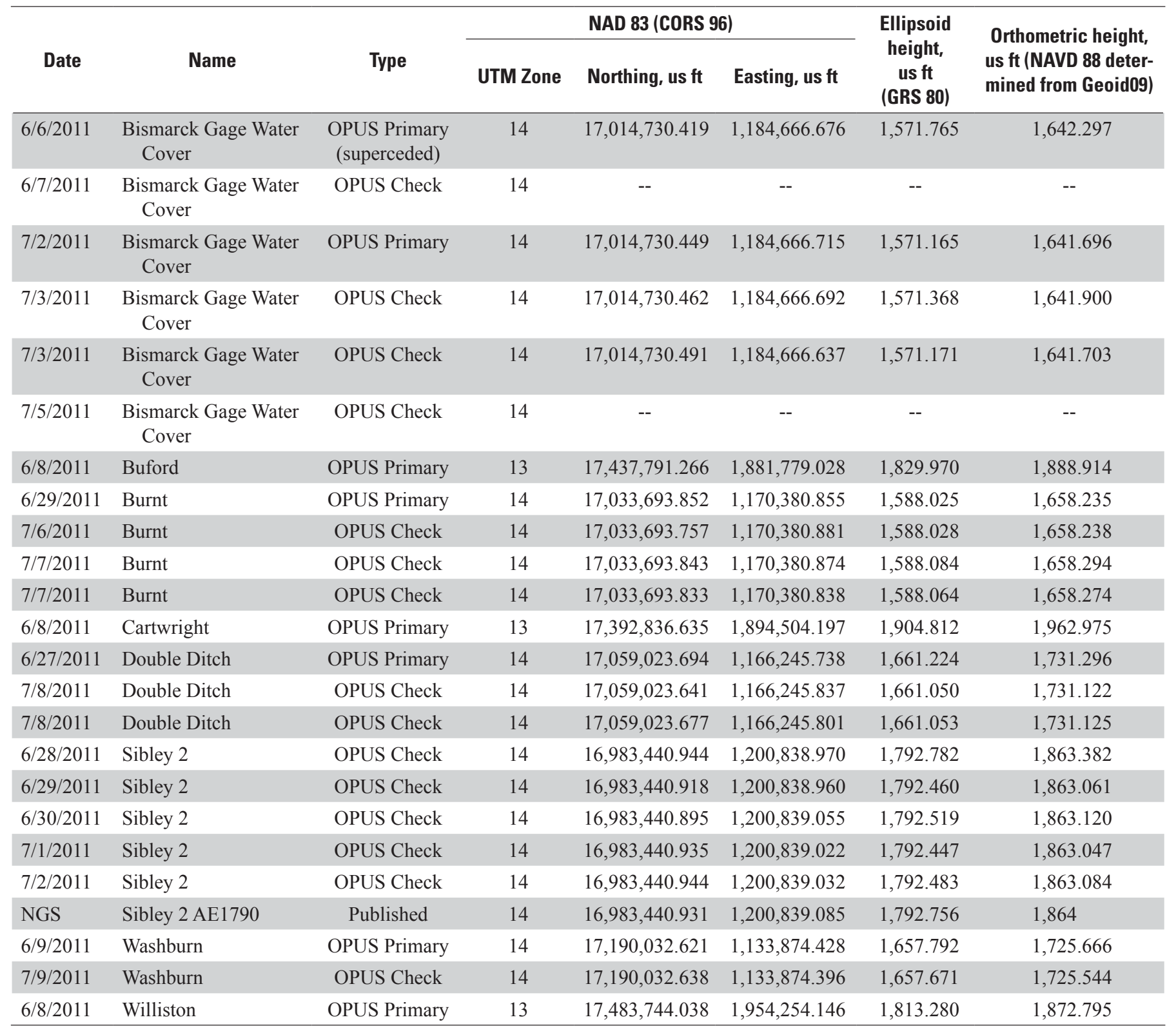




\section{Missouri River at West Bismarck Expressway Bridge, Bismarck, North Dakota}

The West Bismarck Expressway Bridge (ND Hwy 810) crosses the Missouri River in Bismarck, N. Dak. The bridge survey area was surveyed twice during the 2011 flood, on June 6 and July 3, 2011 (table 2). The riverbed elevations surveyed during June 6, 2011, (ranging from 1,600 to 1,630 ft) (fig. 9 and table 4) and during July 3, 2011, (ranging from 1,595 to $1,631 \mathrm{ft}$ ) [fig. 10 (map and elevation scales match scales of fig. 9, the June survey) and table 4] were similar. The daily mean discharge was 122,000 cubic feet per second $\left(\mathrm{ft}^{3} / \mathrm{s}\right)$ during the survey on June 6, 2011, but by the survey on July 3,2011 , the mean daily discharge had increased by 27,000 $\mathrm{ft}^{3} / \mathrm{s}$ to $149,000 \mathrm{ft}^{3} / \mathrm{s}$ (table 5). In both surveys, the lowest bed elevation surveyed was in a scour hole created by a left-bank structure downstream from the bridge (figs. 9 and 10). In this report, the terms "left bank" and "right bank" or "left" and "right" are referenced from the perspective of one looking downstream. Even though the elevation ranges were similar for the two surveys, comparison of the data shows that local bed scour did occur between the first and second surveys. In figure 9, the shallow dune field between the two bridge piers on the left side of the channel had a bed elevation that ranged from approximately 1,617 to $1,627 \mathrm{ft}$ (yellow to orange) during the June survey, but had been scoured to an approximate bed elevation of 1,613 to 1,623 ft by the July survey (fig. 10, no orange). The difference between the June and July surveys is shown in figure 11; much of the area is shown in turquoise and blue hues, representing a positive change in bed elevation between the first and second surveys, defined as a decrease in bed elevation. Other features in the channel changed between the two surveys, including the direction of the left bridge pier scour hole and the deeper channel along the left bank.

On June 6,2011 , the riverbed in the vicinity of four piers of the West Bismarck Expressway Bridge was surveyed, and on July 3, 2011, the riverbed near three piers was surveyed, but neither survey was able to map the riverbed near all the piers. This was because the water level was so near the bridge's deck bottom that not enough clearance remained for the survey boats to pass under the bridge. Scour around the bridge piers was measured in both surveys, but was often greater in the June 6 survey (table 4). The pier nearest the left bank had the deepest scour hole in both surveys, approximately $13 \mathrm{ft}$ with a minimum bed elevation of 1,601 ft during the June survey and $10 \mathrm{ft}$ with a minimum bed elevation of $1,602 \mathrm{ft}$ in the July survey (table 4). During the June survey, the right and the right-middle bridge piers had scour holes approximately 4 and $11 \mathrm{ft}$ deep, respectively.
The configuration of sand dunes on the riverbed was quite different between the two surveys. In the June survey the dunes were located mainly in the left half of the channel (fig. 9). These dunes were approximately $2 \mathrm{ft}$ high (fig. 9). The extent of the sand dunes was much greater in the July 3, 2011, survey, and some dunes, such as those upstream from the bridge, were approximately $3 \mathrm{ft}$ high (green to yellow; fig. 10).

\section{Missouri River at Memorial Highway Bridge, Bismarck, North Dakota}

The Memorial Highway Bridge crosses the Missouri River in Bismarck, N. Dak., and its route is designated Business Loop I-94. The riverbed of the survey area centered on this bridge was surveyed twice during the 2011 flood: on June 7 and July 3, 2011 (table 2). The ranges of bed elevations surveyed during June 7, 2011, (1,595 to 1,634 ft) (fig. 12 and table 4) and during the July 3, 2011, (1,590 to 1,633 ft) [fig. 13 (map and elevation scales match those used for fig. 12, June survey) and table 4] were similar. The daily mean discharge during the July 3, 2011, survey was $28,000 \mathrm{ft}^{3} / \mathrm{s}$ higher than during the June 7, 2011, survey $\left(149,000 \mathrm{ft}^{3} / \mathrm{s}\right.$ and $121,000 \mathrm{ft}^{3} / \mathrm{s}$, respectively; table 5 ). In both surveys, the lowest bed elevation was measured just below a right-bank wing dike downstream from the bridge (figs. 12 and 13). The differences in channel-bed elevations between the June and July surveys are shown in figure 14; areas where general and local scour occurred between the surveys are evident. For the left half of the channel, figure 14 shows a general decrease in bed elevation that is most pronounced along the right side of the submerged island downstream from the bridge. On the right side of the channel, a large area upstream from the bridge was scoured between surveys, whereas some areas downstream from the bridge were scoured and others filled (fig. 14). Numerous sand dunes can be seen on the right half of the riverbed in the July survey results (fig. 13), whereas most dunes were in the left half of the channel in the June survey (fig. 12).

The channel bed in the vicinity of four piers of the Memorial Highway Bridge was mapped during both surveys. Scour around the bridge piers was measured during both surveys, but the depth of the scour holes was greater during the June 7 survey (table 4). The pier nearest the right bank had the greatest extent of scour in the June survey, and in the July survey, it had the deepest scour hole $-6 \mathrm{ft}$, with a minimum bed elevation of 1,606 ft (fig. 13 and table 4). In the June survey, the left middle pier had a 9-ft-deep scour hole with a minimum bed elevation of $1,616 \mathrm{ft}$ (fig. 12 and table 4). 


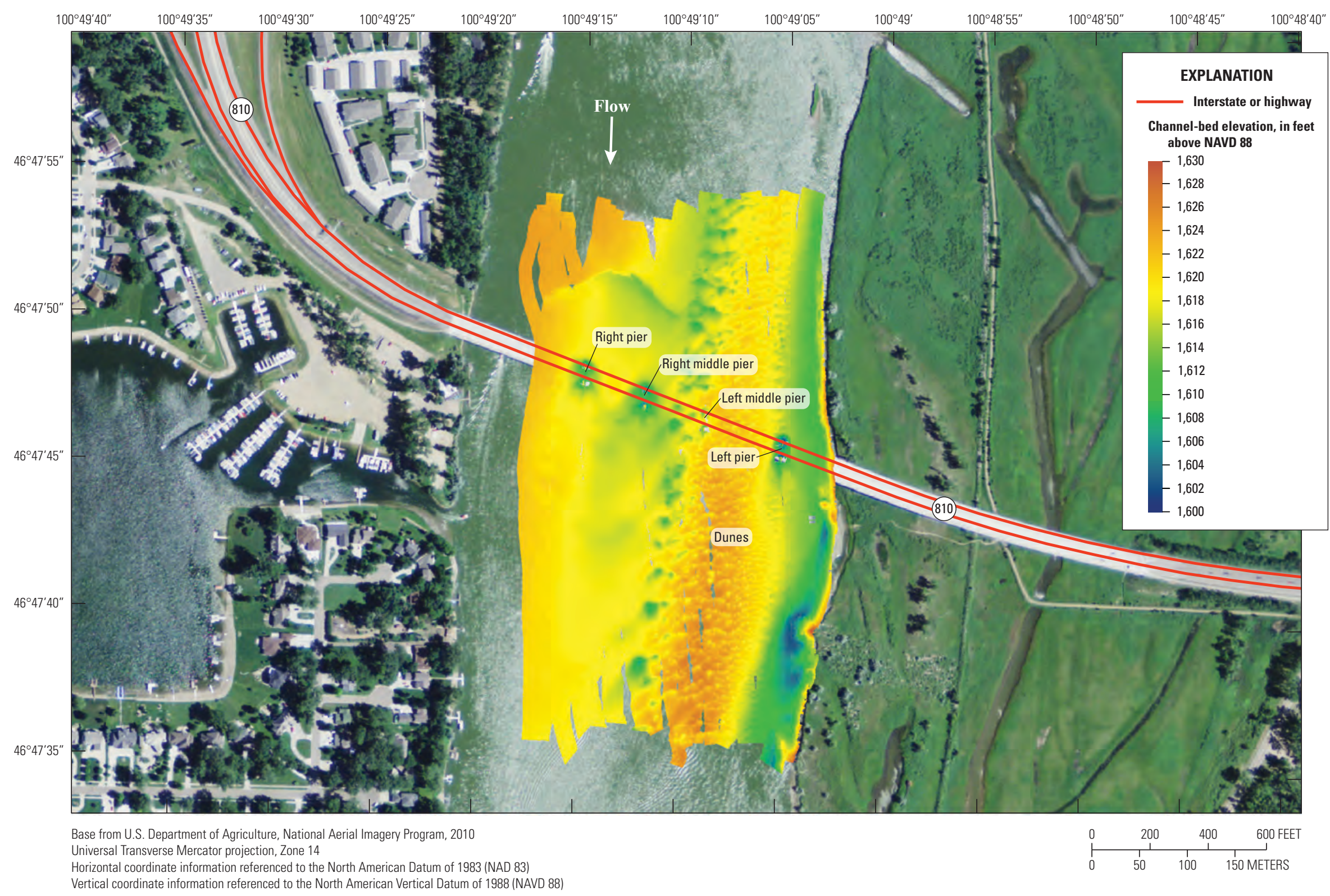

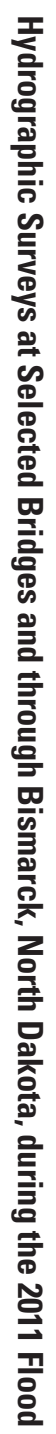

Figure 9. Channel-bed elevations from the Missouri River hydrographic survey at West Bismarck Expressway Bridge, Bismarck, North Dakota, June 6, 2011. 
Table 4. Summary of channel-bed elevations surveyed at selected bridges on the Missouri and Yellowstone Rivers, North Dakota, during the $2011 \mathrm{flood}$.

[NAVD 88, North American Vertical Datum of 1988; us ft, U.S. survey feet; ND, North Dakota; Hwy, highway; na, not applicable; I-94, Interstate 94]

\begin{tabular}{|c|c|c|c|c|c|c|c|c|c|}
\hline \multirow{2}{*}{ Site } & \multirow{2}{*}{$\begin{array}{l}\text { Survey } \\
\text { date }\end{array}$} & \multirow{2}{*}{$\begin{array}{c}\text { Minimum } \\
\text { elevation } \\
\text { (NAVD 88 } \\
\text { us ft) }\end{array}$} & \multirow{2}{*}{$\begin{array}{c}\text { Maximum } \\
\text { elevation } \\
\text { (NAVD } 88 \\
\text { us ft) }\end{array}$} & \multirow{2}{*}{$\begin{array}{c}\text { Number } \\
\text { of bridge } \\
\text { piers } \\
\text { surveyed }\end{array}$} & \multicolumn{5}{|c|}{$\begin{array}{l}\text { Approximate surrounding bed elevation (NAVD } 88 \text { us ft); approximate scour hole minimum } \\
\text { elevation (NAVD } 88 \text { us ft); approximate scour hole depth (ft) }\end{array}$} \\
\hline & & & & & Right pier & Right middle pier & Middle pier & Left middle pier & Left pier \\
\hline $\begin{array}{l}\text { West Bismarck Expressway } \\
\text { Bridge (ND Hwy 810) }\end{array}$ & $6 / 6 / 2011$ & 1,600 & 1,630 & 4 & 1,$613 ; 1,609 ; 4$ & 1,$615 ; 1,604 ; 11$ & na & 1,$616 ; 1,616 ; 0$ & 1,$614 ; 1,601 ; 13$ \\
\hline $\begin{array}{l}\text { West Bismarck Expressway } \\
\text { Bridge (ND Hwy 810) }\end{array}$ & $7 / 3 / 2011$ & 1,595 & 1,631 & 3 & No data & 1,$609 ; 1,606 ; 3$ & na & 1,$620 ; 1,614 ; 6$ & 1,$612 ; 1,602 ; 10$ \\
\hline $\begin{array}{l}\text { Memorial Highway Bridge } \\
\text { (Business Loop I-94) }\end{array}$ & $6 / 7 / 2011$ & 1,595 & 1,634 & 4 & 1,$611 ; 1,603 ; 8$ & 1,$616 ; 1,608 ; 6$ & na & 1,$625 ; 1,616 ; 9$ & 1,$626 ; 1,621 ; 5$ \\
\hline $\begin{array}{l}\text { Memorial Highway Bridge } \\
\text { (Business Loop I-94) }\end{array}$ & $7 / 3 / 2011$ & 1,590 & 1,633 & 4 & 1,$612 ; 1,606 ; 6$ & 1,$615 ; 1,612 ; 3$ & na & 1,$618 ; 1,615 ; 3$ & 1,$620 ; 1,618 ; 2$ \\
\hline Grant Marsh Bridge (I-94) & $6 / 6 / 2011$ & 1,588 & 1,633 & 2 & 1,$610 ; 1,607 ; 3$ & na & na & na & 1,$595 ; 1,616 ;-21$ \\
\hline Grant Marsh Bridge (I-94) & $7 / 5 / 2011$ & 1,584 & 1,632 & 2 & 1,$605 ; 1,599 ; 6$ & na & na & na & 1,$593 ; 1,616 ;-23$ \\
\hline Washburn Bridge (ND Hwy 200) & $6 / 9 / 2011$ & 1,626 & 1,655 & 5 & 1,$647 ; 1,641 ; 6$ & 1,$642 ; 1,633 ; 9$ & 1,$638 ; 1,627 ; 11$ & 1,640; na; na & 1,648; na; na \\
\hline Washburn Bridge (ND Hwy 200) & $7 / 9 / 2011$ & 1,621 & 1,659 & 5 & 1,638; na; na & 1,$638 ; 1,625 ; 13$ & 1,$639 ; 1,621 ; 18$ & 1,$643 ; 1,638 ; 5$ & 1,$649 ; 1,644 ; 5$ \\
\hline Williston Bridge (U.S. Hwy 85) & $6 / 8 / 2011$ & 1,814 & 1,854 & 5 & 1,$823 ; 1,818 ; 5$ & 1,$830 ; 1,820 ; 10$ & 1,$835 ; 1,830 ; 5$ & 1,$844 ; 1,825 ; 19$ & 1,$843 ; 1,832 ; 11$ \\
\hline Buford Bridge (ND Hwy 58) & $6 / 8 / 2011$ & 1,842 & 1,870 & 4 & 1,$855 ; 1,852 ; 3$ & 1,$855 ; 1,852 ; 3$ & na & 1,$852 ; 1,849 ; 3$ & 1,$852 ; 1,842 ; 10$ \\
\hline Cartwright Bridge (ND Hwy 200) & 6/8/2011 & 1,844 & 1,871 & 3 & 1,855; na; na & na & $\begin{array}{l}1,854 ; 1,851.5 \\
\quad 2.5\end{array}$ & na & 1,$859 ; 1,854 ; 5$ \\
\hline
\end{tabular}




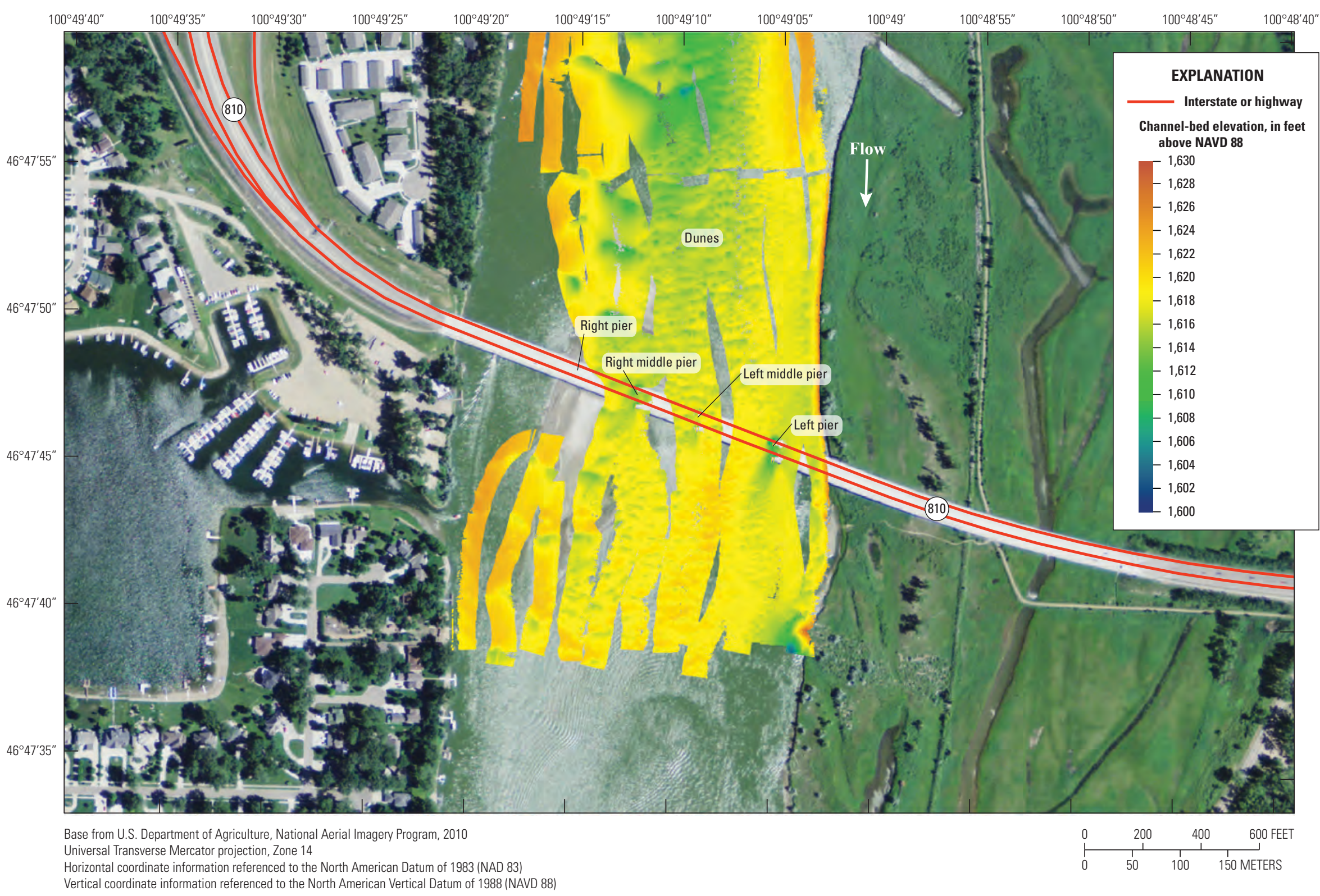

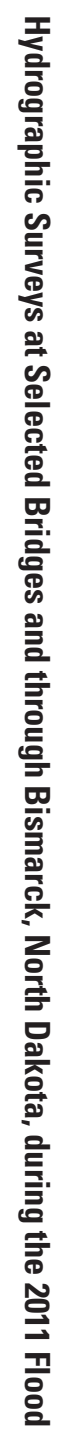

Figure 10. Channel-bed elevations from the Missouri River hydrographic survey at West Bismarck Expressway Bridge, Bismarck, North Dakota, July 3, 2011. 
Table 5. Daily mean gage height and daily mean discharge at selected streamgages during hydrographic surveys of the Missouri and Yellowstone Rivers, North Dakota, during the 2011 flood.

[Data from U.S. Geological Survey, 2012. USGS, U.S. Geological Survey; ft, feet; ft³/s, cubic foot per second; ND, North Dakota; MT, Montana; --, no data]

\begin{tabular}{|c|c|c|c|c|}
\hline Site & Survey date & USGS streamgage & $\begin{array}{c}\text { Daily mean } \\
\text { gage height, } \\
\mathrm{ft}\end{array}$ & $\begin{array}{c}\text { Daily mean } \\
\text { discharge, } \\
\mathrm{ft}^{3} / \mathrm{s}\end{array}$ \\
\hline West Bismarck Expressway Bridge & $6 / 6 / 2011$ & 06342500 Missiouri River at Bismarck, ND & 17.18 & 122,000 \\
\hline Grant Marsh Bridge & $6 / 6 / 2011$ & 06342500 Missiouri River at Bismarck, ND & 17.18 & 122,000 \\
\hline Memorial Highway Bridge & $6 / 7 / 2011$ & 06342500 Missiouri River at Bismarck, ND & 17.05 & 121,000 \\
\hline Cartwright Bridge & 6/8/2011 & 06329500 Yellowstone River near Sidney, MT $^{1}$ & 14.28 & 53,800 \\
\hline Williston Bridge & $6 / 8 / 2011$ & 06330000 Missouri River near Williston, ND² & 27.68 & -- \\
\hline Washburn Bridge & 6/9/2011 & 06342500 Missiouri River at Bismarck, ND ${ }^{3}$ & 17.45 & 136,000 \\
\hline Sector 1 & $6 / 28 / 2011$ & 06342500 Missiouri River at Bismarck, ND & 19.08 & 153,000 \\
\hline Sector 2 & $7 / 2 / 2011$ & 06342500 Missiouri River at Bismarck, ND & 19.08 & 150,000 \\
\hline Sector 5 & $6 / 29 / 2011$ & 06342500 Missiouri River at Bismarck, ND & 19.15 & 149,000 \\
\hline Sector 6 & $6 / 29 / 2011$ & 06342500 Missiouri River at Bismarck, ND & 19.15 & 149,000 \\
\hline Sector 7 & $7 / 3 / 2011$ & 06342500 Missiouri River at Bismarck, ND & 19.05 & 149,000 \\
\hline Sector 8 & $7 / 3 / 2011$ & 06342500 Missiouri River at Bismarck, ND & 19.05 & 149,000 \\
\hline $\begin{array}{c}\text { Sector 9/Memorial Highway/West } \\
\text { Bismarck Expressway Bridges }\end{array}$ & $7 / 3 / 2011$ & 06342500 Missiouri River at Bismarck, ND & 19.05 & 149,000 \\
\hline Sector 10 & $7 / 2 / 2011$ & 06342500 Missiouri River at Bismarck, ND & 19.08 & 150,000 \\
\hline Sector 11/Grant Marsh Bridge & $7 / 5 / 2011$ & 06342500 Missiouri River at Bismarck, ND & 19.06 & 145,000 \\
\hline Sector 12 & $7 / 5 / 2011$ & 06342500 Missiouri River at Bismarck, ND & 19.06 & 145,000 \\
\hline Sector 18 & $7 / 8 / 2011$ & 06342500 Missiouri River at Bismarck, ND & 19.08 & 141,000 \\
\hline Sector 19 & $7 / 8 / 2011$ & 06342500 Missiouri River at Bismarck, ND & 19.08 & 141,000 \\
\hline Sector 20 & $7 / 8 / 2011$ & 06342500 Missiouri River at Bismarck, ND & 19.08 & 141,000 \\
\hline Washburn Bridge & $7 / 9 / 2011$ & 06342500 Missiouri River at Bismarck, ND ${ }^{3}$ & 19.15 & 143,000 \\
\hline
\end{tabular}

${ }^{1}$ Gage more than 20 miles upstream from site.

${ }^{2}$ Stage-only streamgage. Nearest streamgage with discharge is Culbertson, Montana, but it is upstream from the confluence of the Missouri and Yellowstone Rivers.

${ }^{3}$ Gage more than 35 miles downstream from site. 


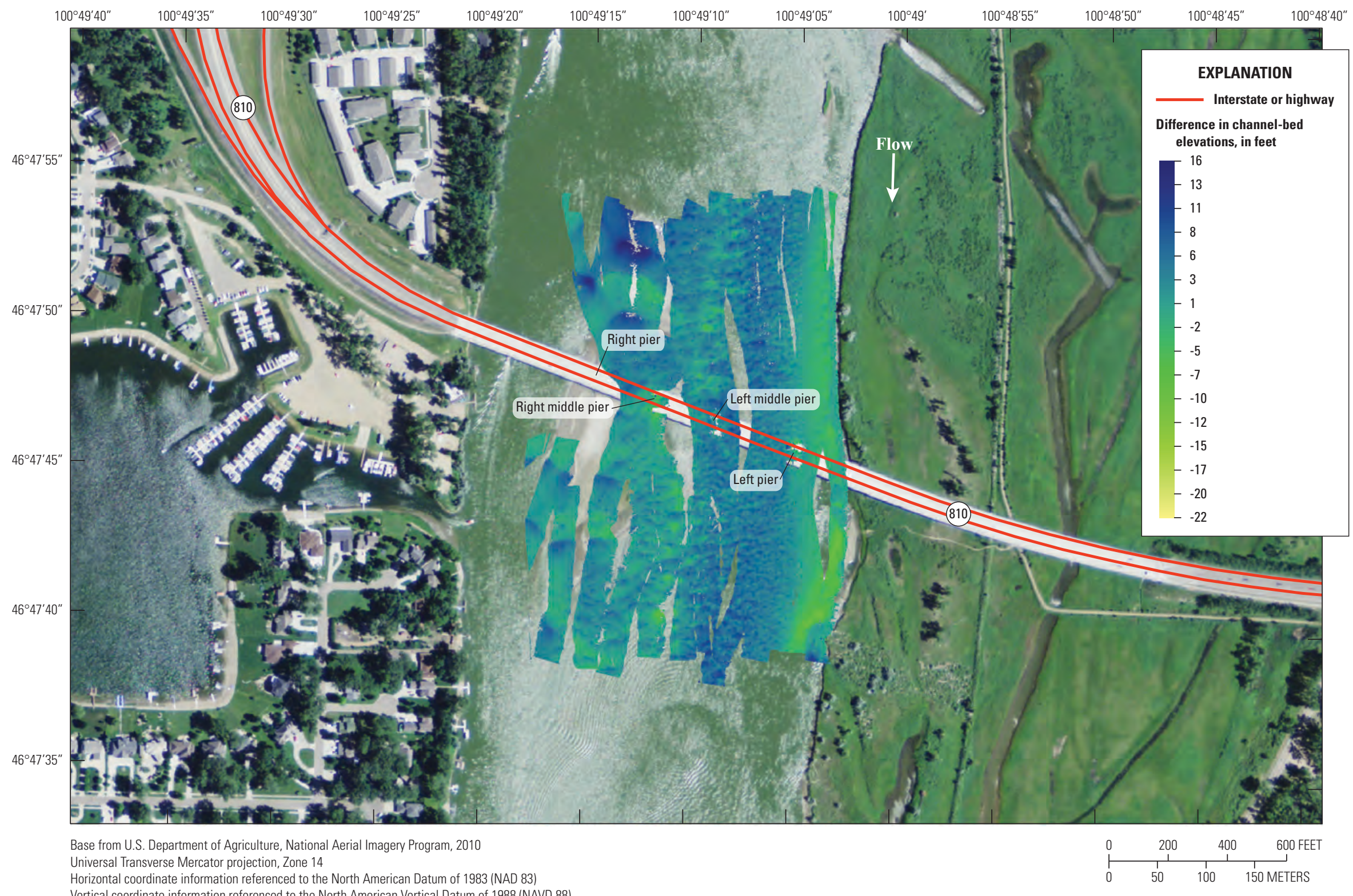

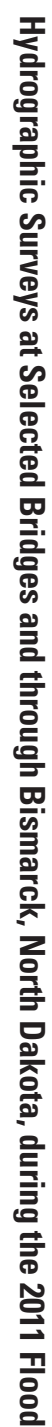

or projection, Zone 14

Vertical coordinate information referenced to the North American Vertical Datum of 1988 (NAVD 88)

Figure 11. Difference in channel-bed elevations between the June 6 and July 3, 2011, hydrographic surveys of the Missouri River at West Bismarck Expressway Bridge, Bismarck, North Dakota. (Positive elevation difference corresponds to erosion or scour; negative difference indicates deposition or fill.) 


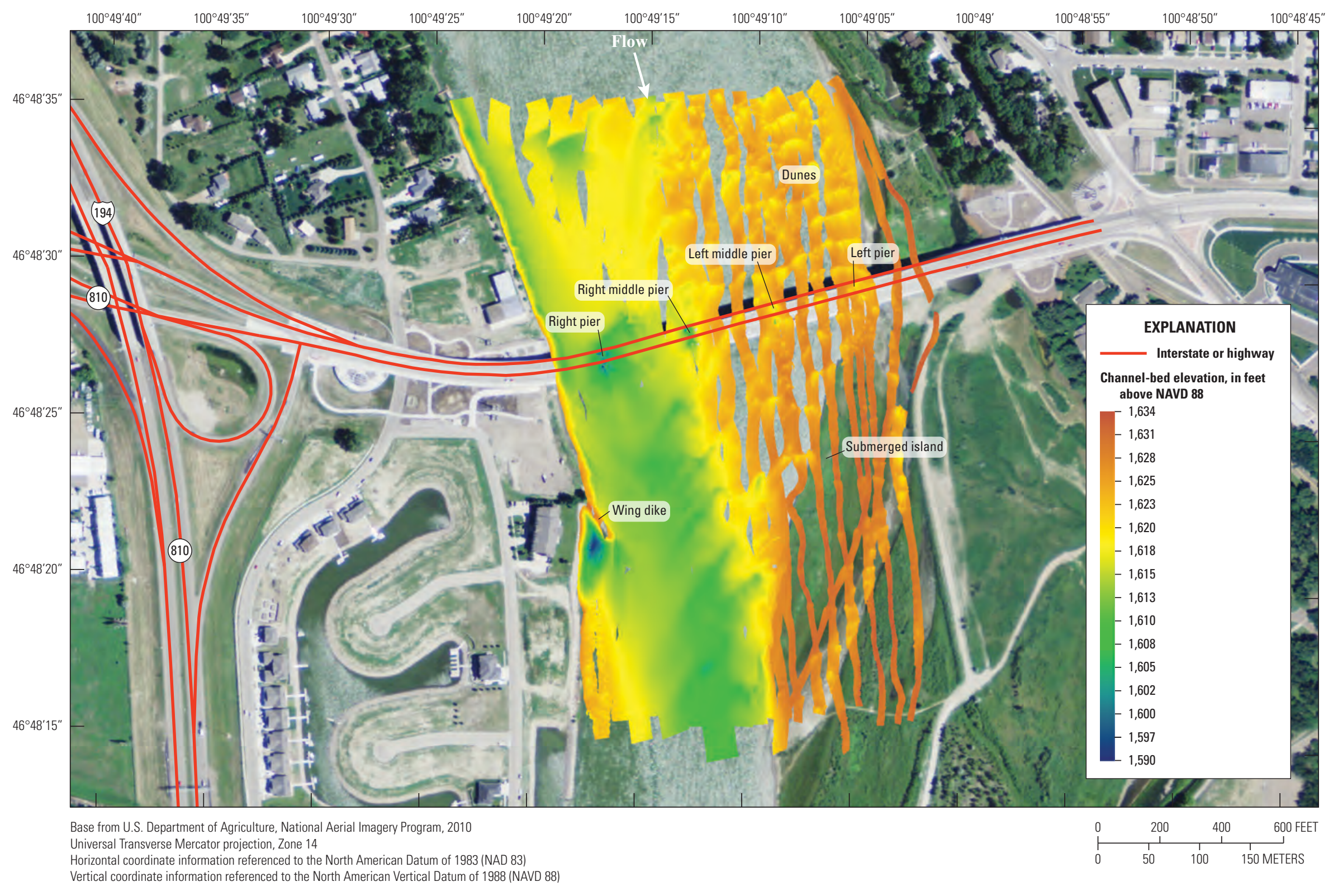

Figure 12. Channel-bed elevations from the Missouri River hydrographic survey at Memorial Highway Bridge, Bismarck, North Dakota, June 7, 2011. 


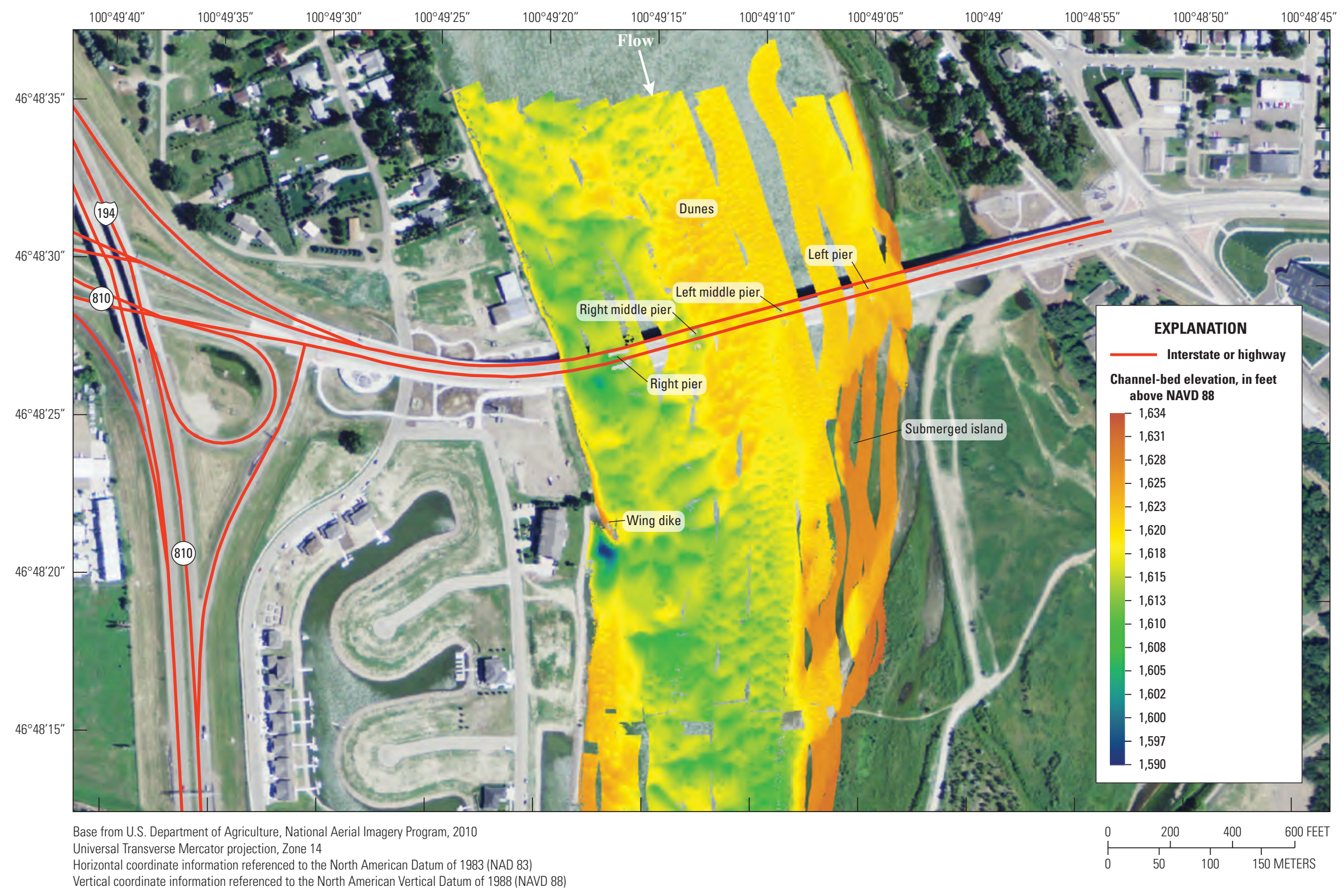

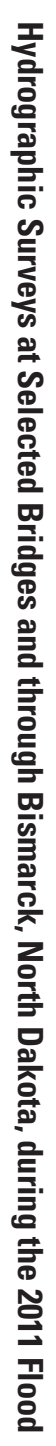

Figure 13. Channel-bed elevations from the Missouri River hydrographic survey at Memorial Highway Bridge, Bismarck, North Dakota, July 3, 2011. 


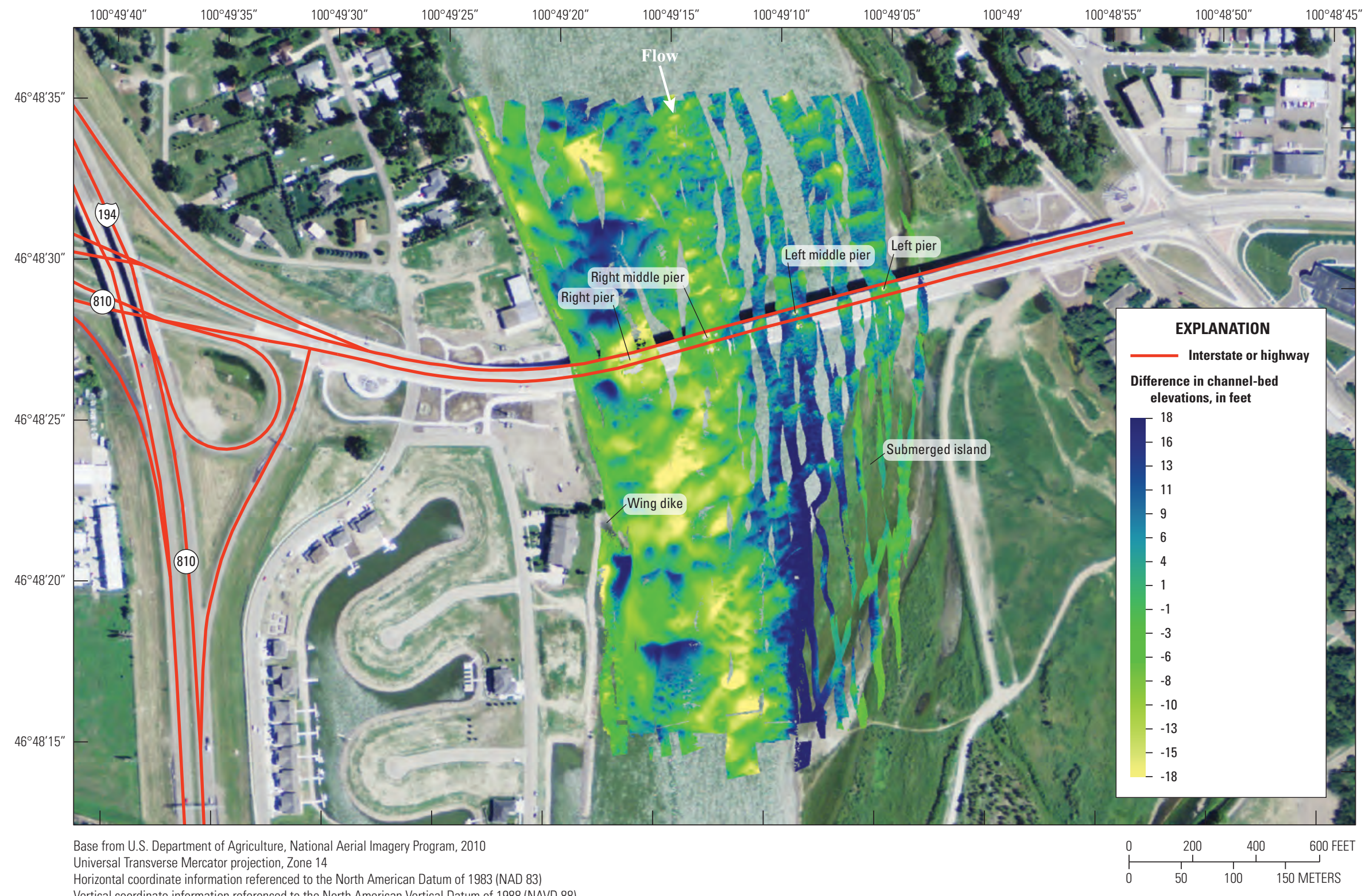

Figure 14. Difference in channel-bed elevations between June 7 and July 3, 2011, hydrographic surveys on the Missouri River at Memorial Highway Bridge, Bismarck, North Dakota. (Positive elevation difference corresponds to erosion or scour; negative difference indicates deposition or fill.) 


\section{Missouri River at Grant Marsh Bridge, Bismarck, North Dakota}

The riverbed of the survey area centered on Interstate-94 Bridge over the Missouri River, called the Grant Marsh Bridge, Bismarck, N. Dak., was surveyed twice during the 2011 Missouri River flood: once on June 6, 2011, and again on July 5,2011 . The bed elevations ranged from 1,588 to $1,633 \mathrm{ft}$ on June 6, 2011 (fig. 15 and table 4) and from 1,584 to 1,632 ft on July 5, 2011 [fig. 16 (map and elevation scales match those used for fig. 15, June survey) and table 4]. The daily mean discharge as recorded at the Missouri River at Bismarck, streamgage 06342500 , on June 6,2011 , was $122,000 \mathrm{ft}^{3} / \mathrm{s}$ and on July 5, 2011, was $145,000 \mathrm{ft}^{3} / \mathrm{s}$, a difference of $23,000 \mathrm{ft}^{3} / \mathrm{s}$. The minimum bed elevation for the June 6, 2011, survey was located in the main channel downstream from the left pier, but in the July 5, 2011, survey, it was in the main channel upstream from the bridge near the right bank. The map of the elevation differences between the two surveys shows this change (fig. 17) and indicates general deposition occurred from the left bank downstream from the bridge out into the main channel, whereas in the left half of the channel upstream from the bridge, scour was more localized, but quite intense (fig. 17). The general scour in the right half of the channel that occurred between surveys removed much of the sand dunes evident in the area of river downstream from the bridge. The dunes were approximately $3 \mathrm{ft}$ high during the June 6, 2011, survey and $1.5 \mathrm{ft}$ high during the July 5, 2011, survey (figs. 15 and 16).

The riverbed in the vicinity of two piers, described here as the left and the right piers, of the Grant Marsh bridge (I-94) was surveyed on June 6, 2011, and July 5, 2011. Other piers were within the wetted channel, but the area around them was too shallow for MBES surveying. Minimal scour depth (3 ft) was surveyed around the pier nearest the right bank on June 6, 2011, but during the July 5, 2011, survey the scour hole was $6 \mathrm{ft}$ deep (table 4). The left pier did not have a scour hole because of the protective material surrounding it (figs. 15 and 16). The highest elevation of the protective material was approximately $1,616 \mathrm{ft}$ during both surveys, and the lowest elevation of the channel surrounding the protective material was approximately $1,595 \mathrm{ft}$ on June 6,2011 , and $1,593 \mathrm{ft}$ on July 5,2011 . These results show that the protective material is piled approximately 21 to $22 \mathrm{ft}$ above the streambed (table 4). However, the survey results also revealed that a large amount of the protective material is now downstream from the bridge pier (figs. 15 and 16).

\section{Missouri River at Washburn Bridge near Washburn, North Dakota}

The state highway bridge that crosses the Missouri River near Washburn, N. Dak., is called the Washburn Bridge (ND Hwy 200). The riverbed of the survey area centered on this bridge was surveyed twice during the 2011 flood: on June 9 and July 9, 2011 (table 2). The bed elevations surveyed on June 9, 2011, ranged from 1,626 to 1,655 ft (fig. 18 and table 4) and on July 9, 2011, from 1,621 to 1,659 ft [fig. 19 (map and elevation scales match those used for fig. 18, June survey) and table 4]. The daily mean discharge of the Missouri River at Bismarck (as recorded at streamgage 06342500, more than 35 mi downstream from the survey area) on June 9, 2011, was $136,000 \mathrm{ft}^{3} / \mathrm{s}$ and on July 9, 2011, was $143,000 \mathrm{ft}^{3} / \mathrm{s}$, a difference of $7,000 \mathrm{ft}^{3} / \mathrm{s}$ between the two hydrographic surveys. The lowest bed elevations surveyed during the June survey were in the upstream section of the survey area in the main channel and around the middle pier (fig. 18). The lowest bed elevations surveyed in the July survey were around the middle pier (fig. 19). The map of elevation differences (fig. 20), shows an area of deposition upstream from the bridge on the left side of the channel. The map also shows that scour occurred all along the right bank. The location and type of dunes changed between the June and July surveys. The elevation difference map (fig. 20) highlights some of these areas just upstream from the bridge in the center of the channel and along the right bank downstream from the bridge.

The riverbed in the vicinity of five piers of the Washburn Bridge (ND Hwy 200) was mapped during both surveys. The deepest scour hole for both surveys was around the middle pier, where scour-hole depth was $11 \mathrm{ft}$ in June and $18 \mathrm{ft}$ in July; however, the surrounding bed elevation was similar during the two surveys. The left-middle and left piers had very minimal scour around them during the June survey, but had scour holes approximately $5 \mathrm{ft}$ deep in July (table 4). The right-middle pier had a 9-ft-deep scour hole during the June survey, which increased to a 13-ft-deep scour hole during the July survey; in addition, the surrounding bed elevation decreased $4 \mathrm{ft}$ between the two surveys. During both surveys, the footings were detected around the middle pier (fig. 21C-F). The minimum bed elevation in the scour hole around the middle pier was approximately 1,627 ft in June, and only some parts of the footing were detected in the MBES data. In the July survey, the minimum bed elevation in the scour hole around the middle pier was approximately $1,621 \mathrm{ft}$, and much more of the footing structure was exposed. Hydrographic data collected around the middle pier during the July survey, as viewed from above ( $C$ and $D$ ) and from the side $(E$ and $F$ ), are shown in figure 21 as a triangulated irregular network (TIN) modeled surface and as raw data points. 


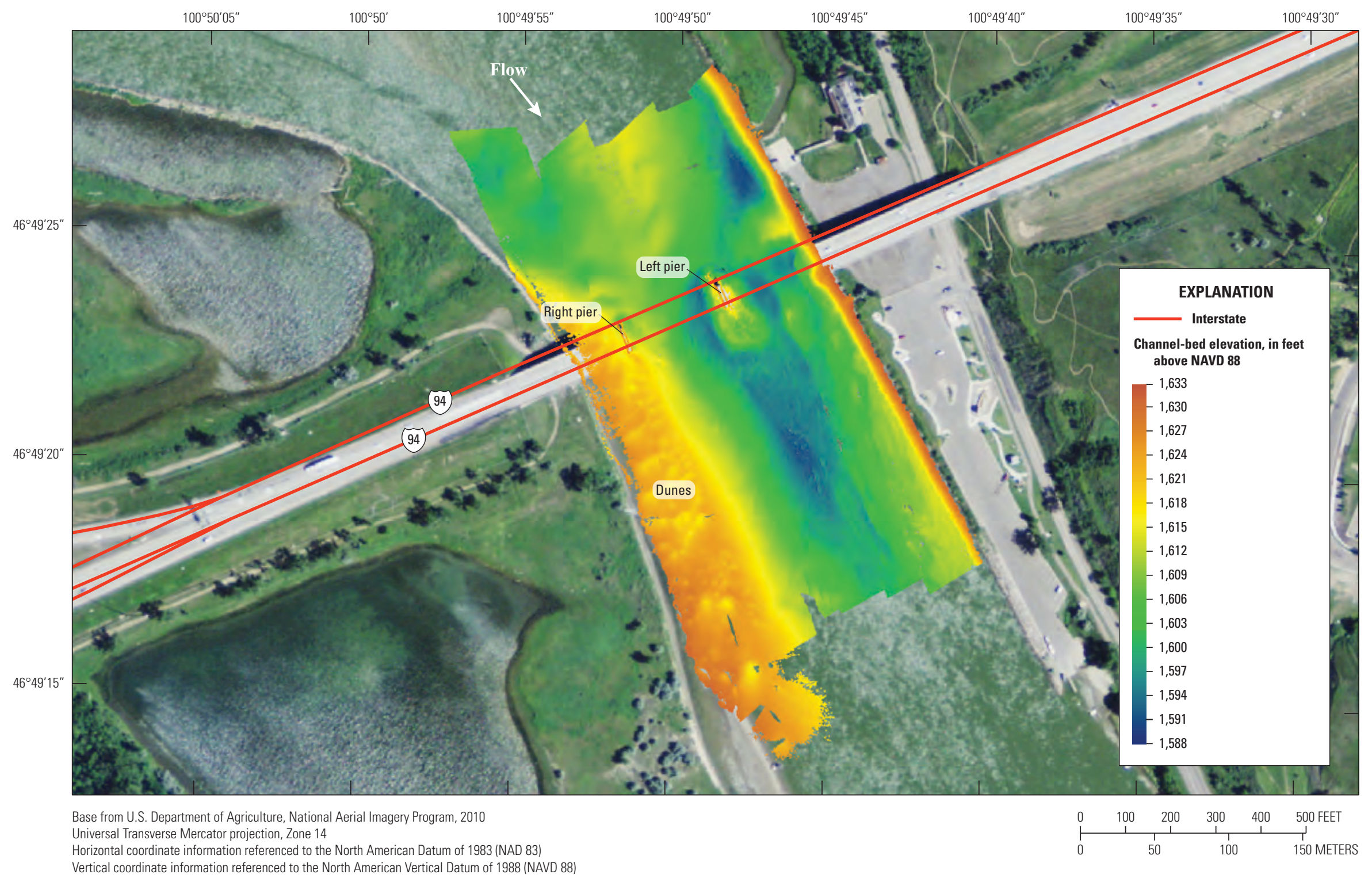

Figure 15. Channel-bed elevations from the Missouri River hydrographic survey at Grant Marsh Bridge, Bismarck, North Dakota, June 6, 2011. 


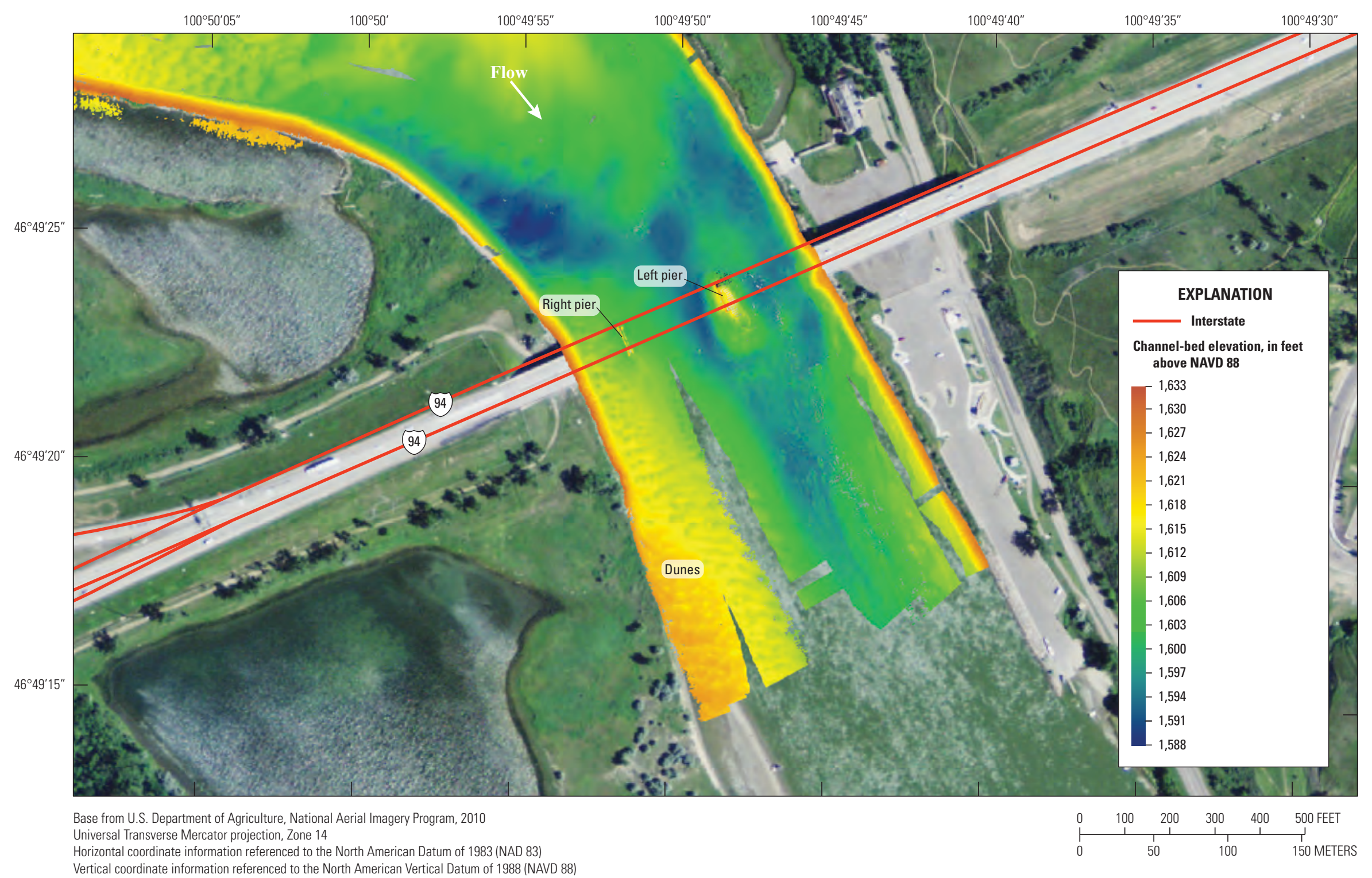

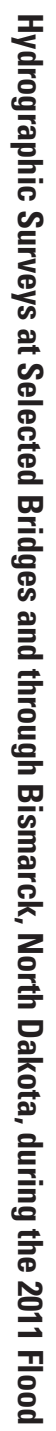

Figure 16. Channel-bed elevations from the Missouri River hydrographic survey at Grant Marsh Bridge, Bismarck, North Dakota, July 5, 2011. 


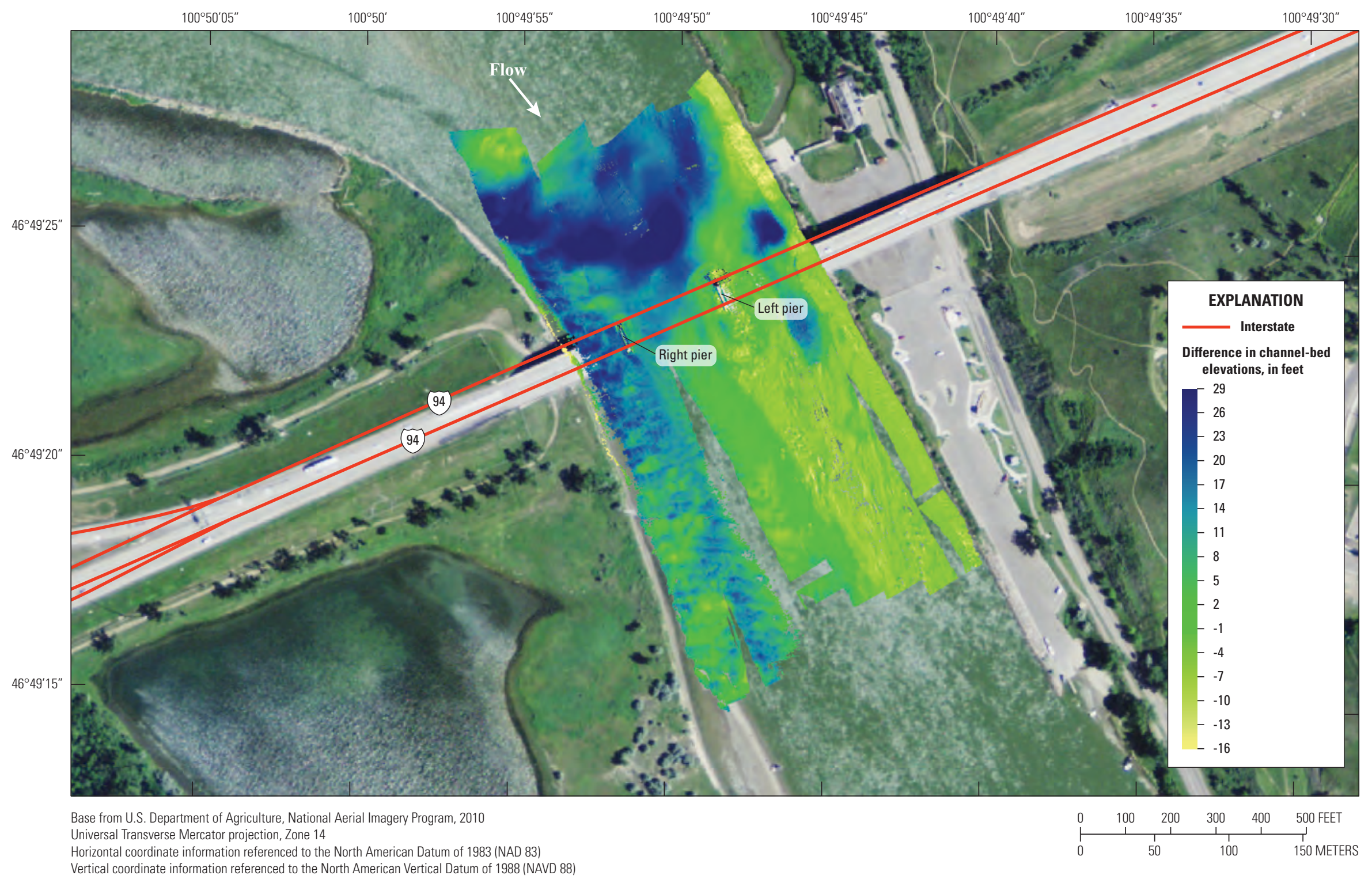

Figure 17. Difference in channel-bed elevations between June 6 and July 5, 2011, hydrographic surveys on the Missouri River at Grant Marsh Bridge, Bismarck, North Dakota. (Positive elevation difference corresponds to erosion or scour; negative difference indicates deposition or fill.) 


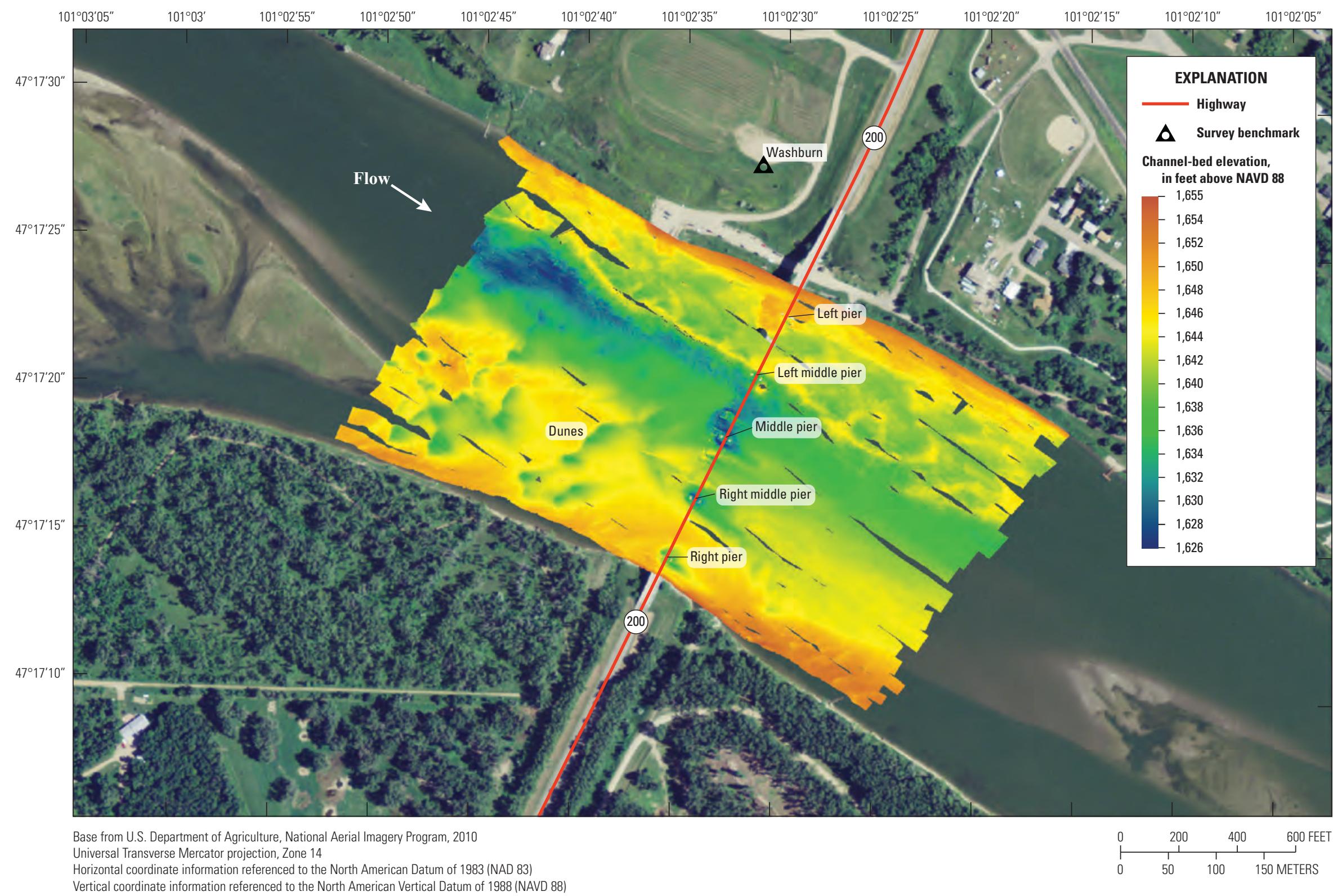

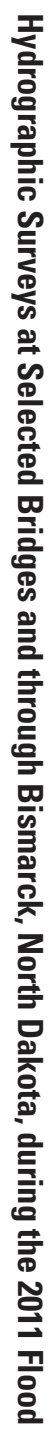

Figure 18. Channel-bed elevations from the Missouri River hydrographic survey at Washburn Bridge, near Washburn, North Dakota, June 9, 2011. 


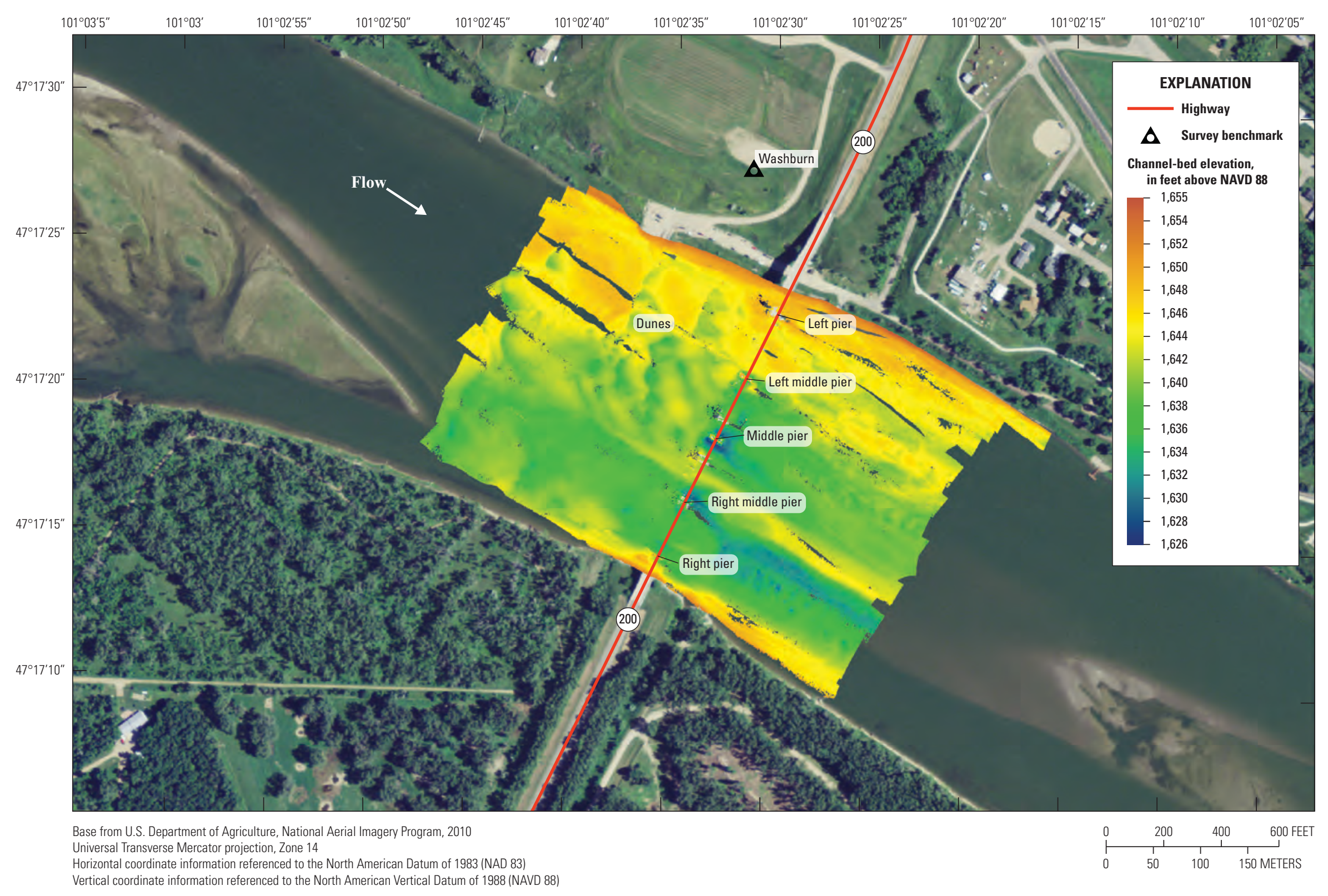

Figure 19. Channel-bed elevations from the Missouri River hydrographic survey at Washburn Bridge, near Washburn, North Dakota, July 9, 2011. 


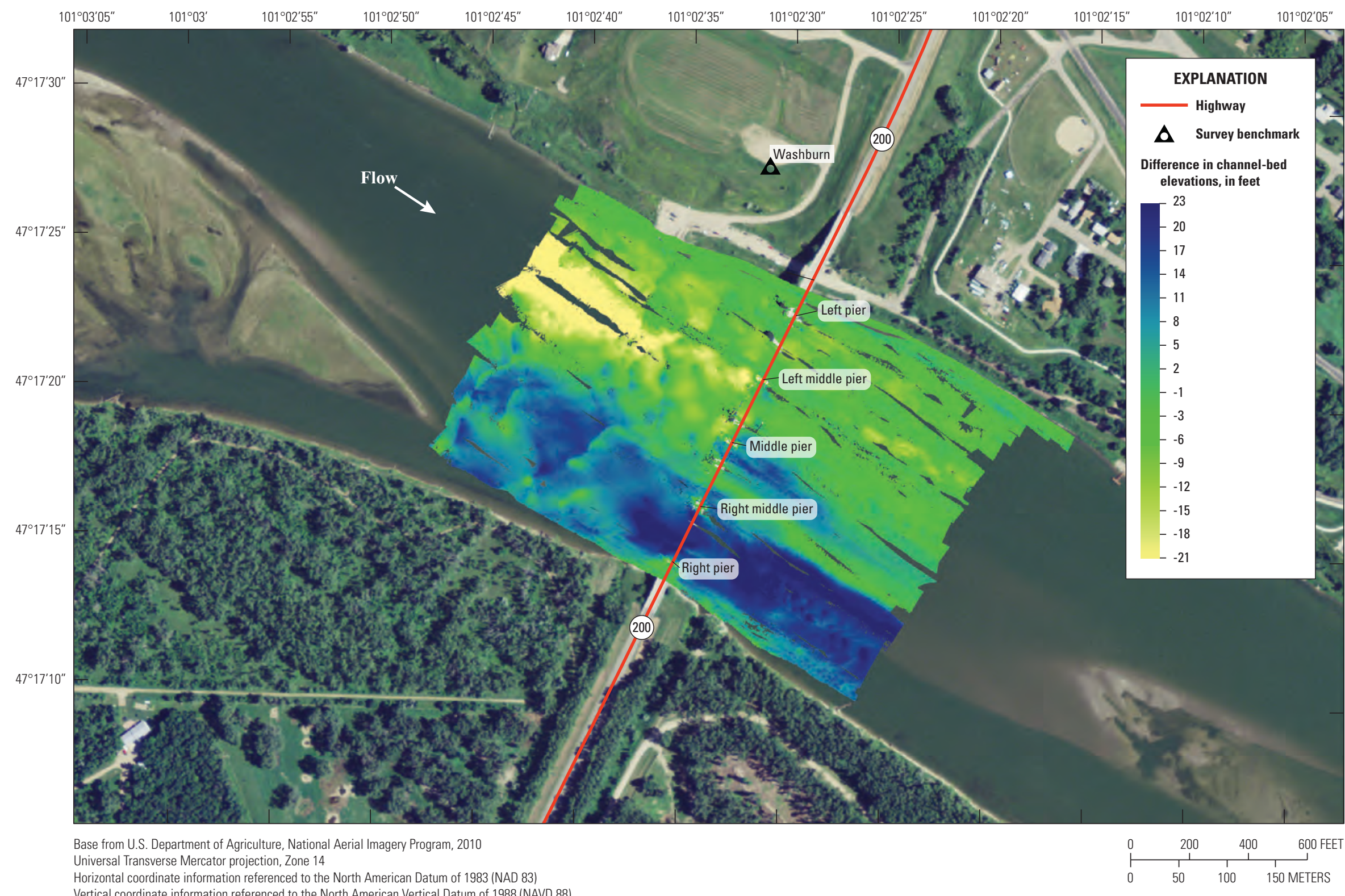

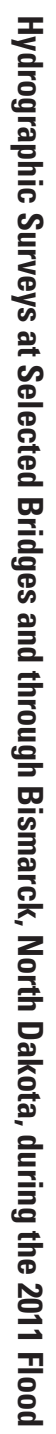

Vertical coordinate information referenced to the North American Vertical Datum of 1988 (NAVD 88 )

Figure 20. Difference in channel-bed elevations between June 9 and July 9, 2011, hydrographic surveys on the Missouri River at Washburn Bridge near Washburn, North Dakota. (Positive elevation difference corresponds to erosion or scour; negative difference indicates deposition or fill.) 


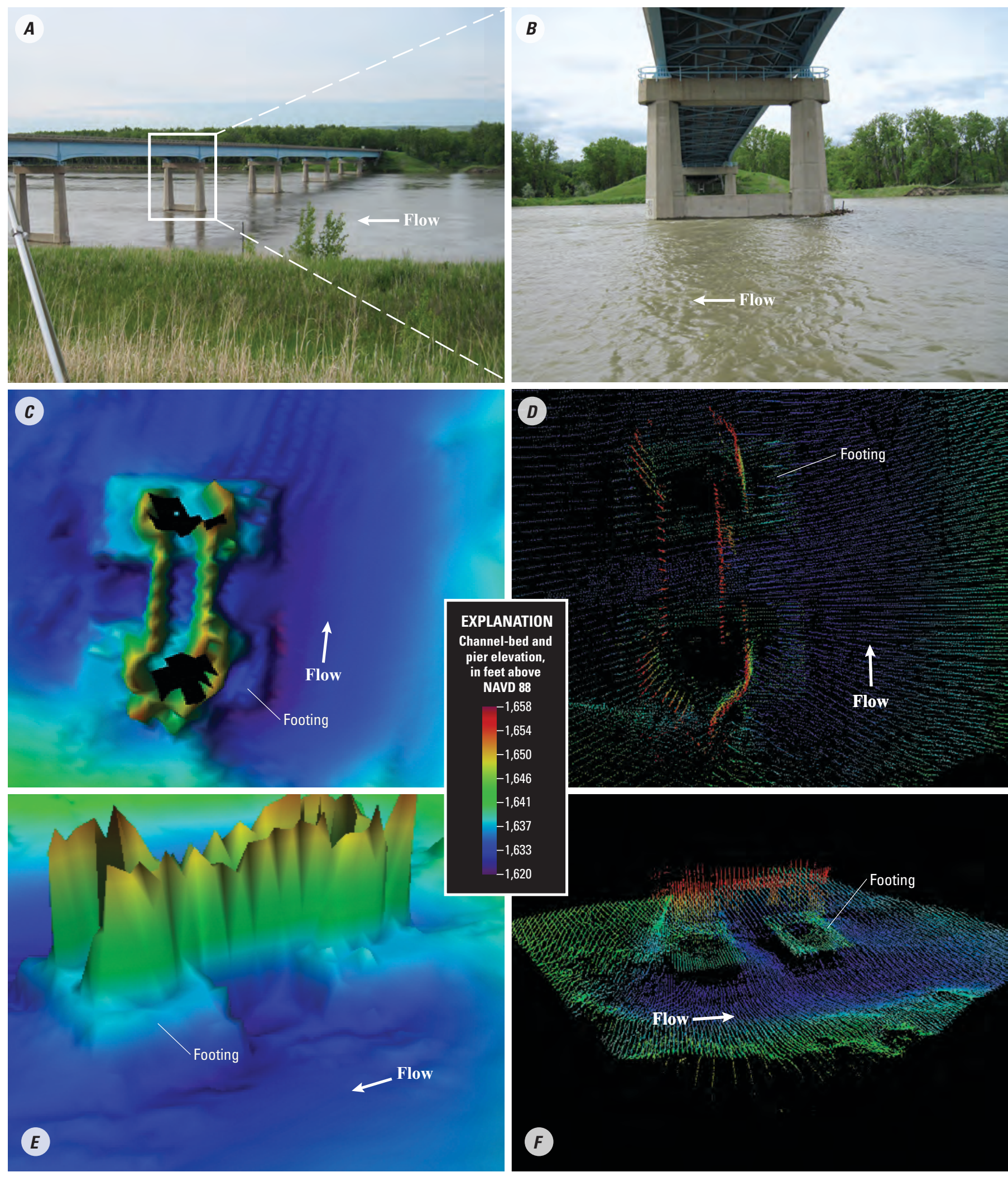

Figure 21. Results of hydrographic survey on July 9, 2011, of middle pier of Washburn Bridge near Washburn, North Dakota, showing exposed footing: $(A)$ Photograph showing Washburn Bridge near Washburn, North Dakota; $(B)$ photograph showing middle pier; $(C)$ triangulated irregular network- (TIN-) rendered surface (CARIS, 2013a) of the middle pier modeled from the survey data; $(D)$ raw multibeam sonar point data of the middle pier, as viewed from above; and $(E)$ TIN-rendered surface of left side of the middle pier. The top of the pier appears jagged due to the number of data points at the upper limits of esonification and the TIN method of interpolation. The ridges on the pier are most likely an artifact of the data due to small errors in the sonar mounting angle not corrected for in data processing and the accuracy of the data points from a vertical surface or are actually representative of the pier structure. $(F)$ right side of middle pier shown using raw multibeam sonar point data. (Photographs by Richard J. Huizinga, U.S. Geological Survey, June 9, 2011). 


\section{Missouri River at Williston Bridge near Williston, North Dakota}

The Federal highway bridge that crosses the Missouri River near Williston, N. Dak., is known as the Williston Bridge (U.S. Hwy 85). The riverbed in the bridge survey area was surveyed once during the 2011 flood, on June 8, 2011 (table 2). The surveyed bed elevations ranged from 1,814 to $1,854 \mathrm{ft}$ (fig. 22 and table 4 ). The stage-only streamgage of the Missouri River near Williston, N. Dak., (streamgage 06330000 ) recorded the daily mean stage on June 8,2011 , as $27.68 \mathrm{ft}$. The daily mean discharge of the Missouri River at Williston was approximated from the discharge recorded at the most downstream Yellowstone River streamgage near Sidney, Mont. (streamgage 06329500; fig. 4) plus the discharge recorded at the closest Missouri River streamgage upstream from Williston (upstream from Yellowstone River confluence near Culbertson, Mont., streamgage 06185500; fig. 4) on June 8, 2011; the sum is $115,300 \mathrm{ft}^{3} / \mathrm{s}$. The lowest bed elevation surveyed was near the right pier (fig. 22). A structure located between the right and the right-middle pier and just downstream from the piers can be seen in the survey results in figure 22. This structure was submerged during the survey, but had visible debris caught on it. A similar structure, also detected in the results, was just downstream from the middle pier. The survey showed a long, linear, and vertical feature extending from the structure located by the middle-right pier towards the right pier. The deepest scour hole observed during the survey was at the middle-left pier and was approximately $19 \mathrm{ft}$ deep with a minimum elevation in the scour hole of $1,825 \mathrm{ft}$ (table 4). The large dunes surveyed downstream from the bridge in the right or main channel were approximately $9 \mathrm{ft}$ in height [1,824 ft (blue/green) to 1,833 ft (yellow/green)], whereas the dunes between the left bank and the island downstream from the bridge were approximately $6 \mathrm{ft}$ tall $(1,840-1,846 \mathrm{ft})$.

\section{Missouri River at Buford Bridge near Buford, North Dakota}

The State highway bridge that crosses the Missouri River near Buford, N. Dak., is known as the Buford Bridge (ND Hwy 58). The bridge area was surveyed once during the 2011 flood, on June 8, 2011 (table 2). The bed elevations surveyed ranged from 1,842 to $1,870 \mathrm{ft}$ (fig. 23 and table 4). The daily mean discharge recorded at the Missouri River near Culbertson, Mont., (streamgage 06185500) on June 8, 2011, was $61,500 \mathrm{ft}^{3} / \mathrm{s}$. The Culbertson, Mont., streamgage is approximately 34 river miles upstream from the Buford Bridge. On June 8, 2011, the lowest bed elevation surveyed at the Buford Bridge survey area was located just upstream from the left pier (fig. 23). The riverbed in the vicinity of four piers was surveyed at the Buford Bridge in June. The deepest scour hole surveyed was at the left pier and was approximately $10 \mathrm{ft}$ deep with a minimum elevation in the scour hole of $1,842 \mathrm{ft}$ (table 4). The pier footing was exposed in the survey results around the pier nearest the left bank at this site. The large dunes indicated in the survey results throughout the reach were approximately $3 \mathrm{ft}$ in height.

\section{Yellowstone River at Cartwright Bridge near Cartwright, North Dakota}

The State highway bridge that crosses the Yellowstone River near Cartwright, N. Dak., is known as the Cartwright Bridge (ND Hwy 200). The riverbed in the bridge survey area was surveyed once during the 2011 flood, on June 8, 2011 (table 2). The bed elevations ranged from 1,844 to $1,871 \mathrm{ft}$ (fig. 24 and table 4). The daily mean discharge recorded at the Yellowstone River near Sidney, Mont., (streamgage 06329500) on June 8, 2011, was 53,800 ft $3 / \mathrm{s}$. The Sidney streamgage is approximately 21 river miles upstream from the Cartwright Bridge. On June 8, 2011, the lowest bed elevation surveyed at the Cartwright Bridge survey area was located in the center of the channel upstream from the bridge (fig. 24). The riverbed in the vicinity of three piers was surveyed at the Cartwright Bridge. Scour around the piers was minimal with the deepest scour hole being $5 \mathrm{ft}$ deep around the left pier (table 4). The largest sand dunes surveyed were upstream from the left pier and were approximately $2 \mathrm{ft}$ high (fig. 24). An old bridge pier in the left part of the channel downstream from the existing bridge was revealed in survey results, and a gap in the data occurred around a second old bridge pier located in the right half of the channel. 


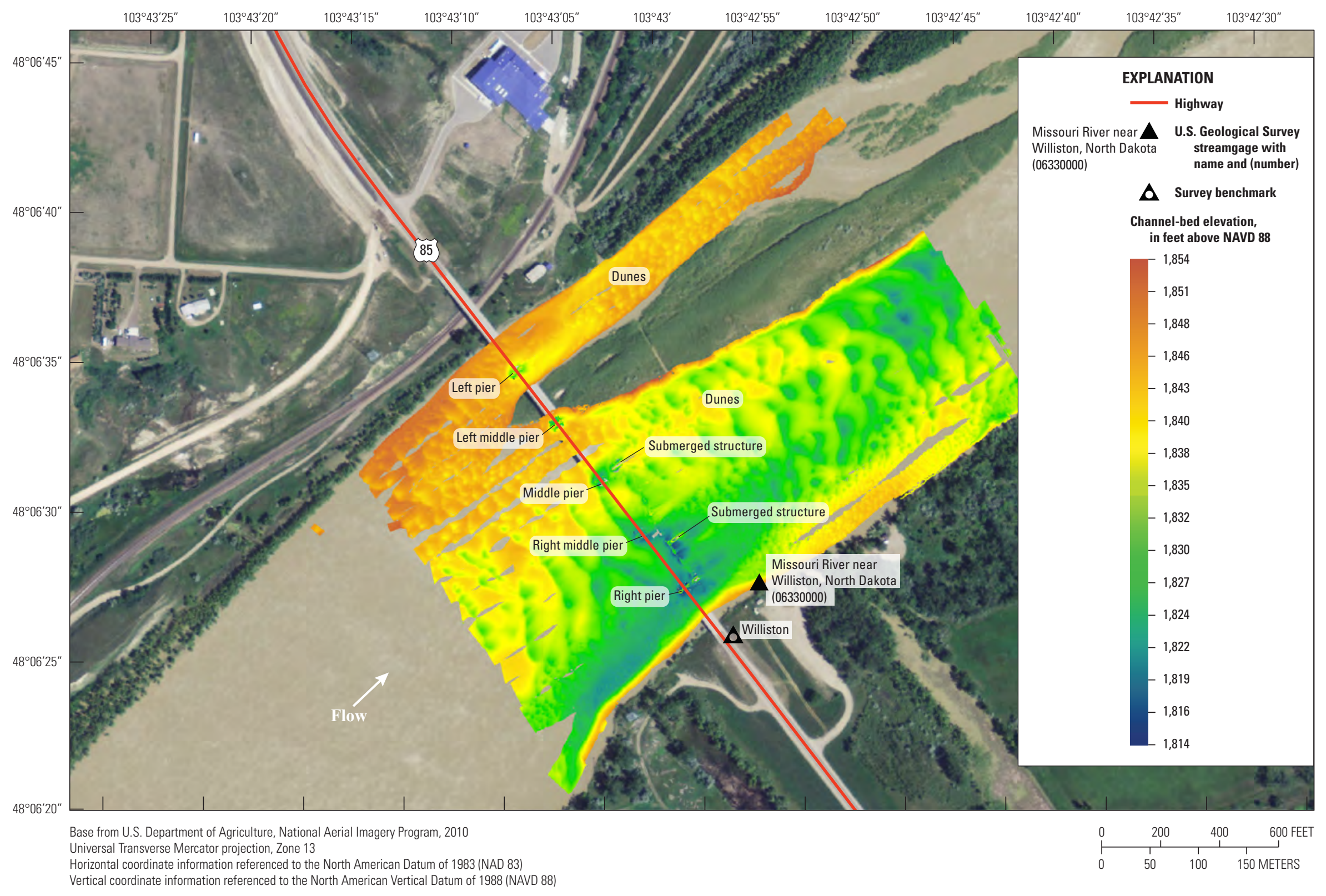

Figure 22. Channel-bed elevations from the Missouri River hydrographic survey at Williston Bridge near Williston, North Dakota, June 8, 2011. 


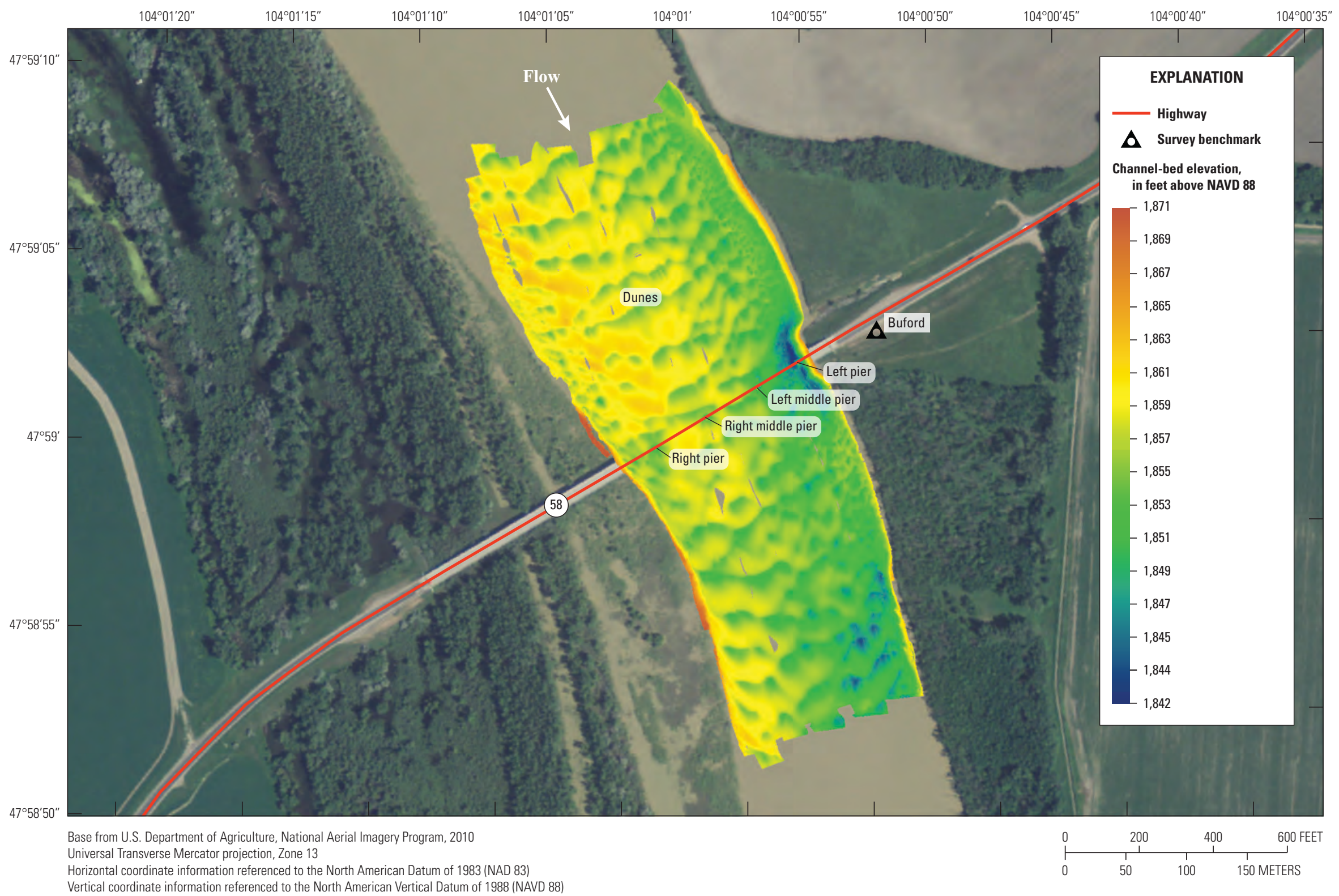

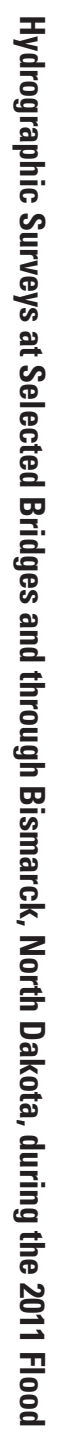

Figure 23. Channel-bed elevations from the Missouri River hydrographic survey at Buford Bridge near Buford, North Dakota, June 8, 2011. 


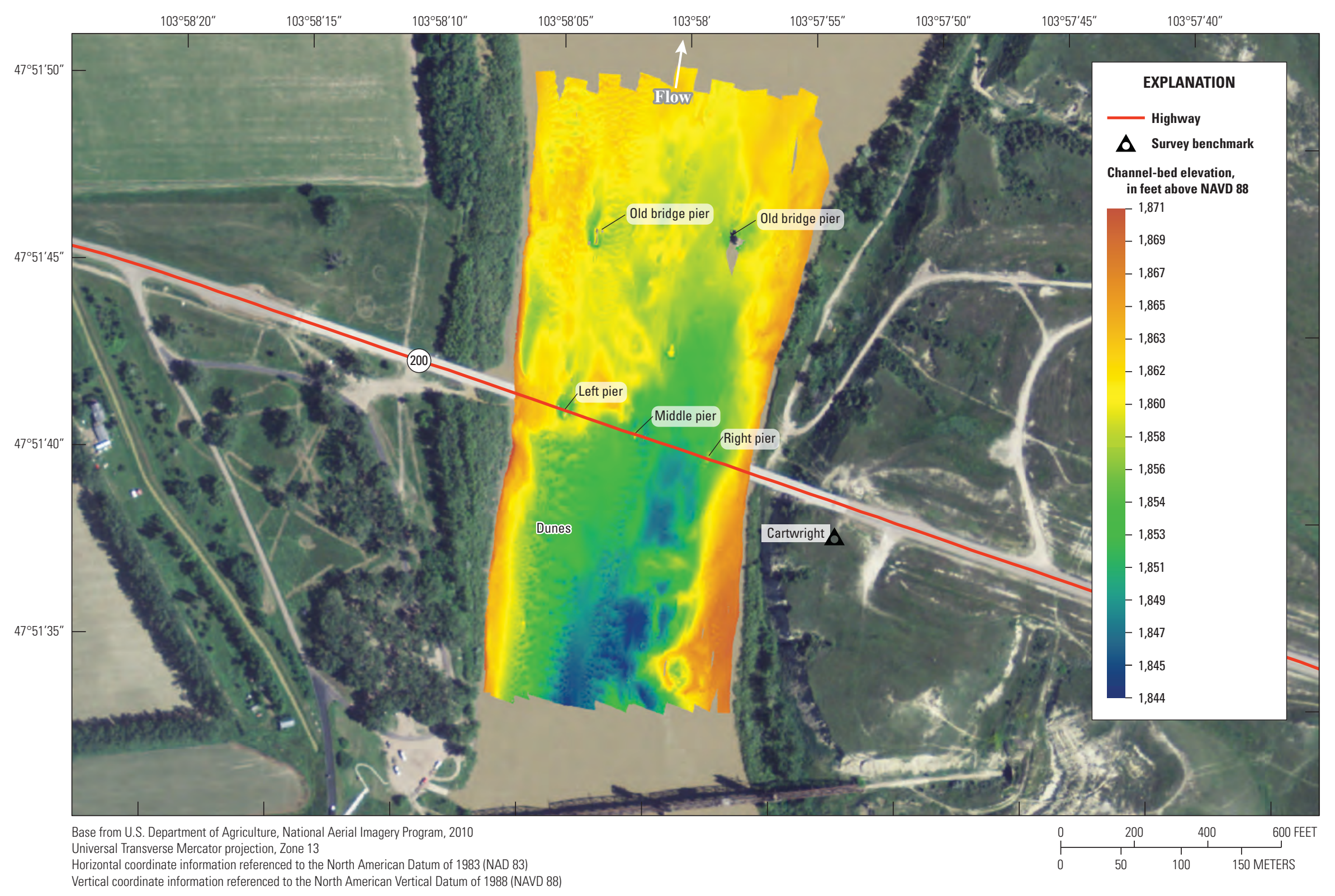

Figure 24. Channel-bed elevations from the Yellowstone River hydrographic survey at Cartwright Bridge near Cartwright, North Dakota, June 8, 2011. 


\section{Hydrographic Surveys of the Missouri River through Bismarck, North Dakota}

The main channel of the Missouri River through Bismarck, N. Dak., was surveyed June 28 through July 8, 2011. The survey area extended from Sibley Bend near the University of Mary to Double Ditch Indian Village State historic site, a reach length of approximately 18 river miles, which was divided into 20 survey sectors (fig. 2). Benchmarks used for surveys of this section of the Missouri River include the NGS benchmark Sibley 2 and three newly established benchmarks designated as Bismarck Gage Water Cover, Burnt, and Double Ditch (table 3). During the Bismarck reach surveys, Missouri River daily mean flows ranged from $153,000 \mathrm{ft}^{3} / \mathrm{s}$ to $141,000 \mathrm{ft}^{3} / \mathrm{s}$ at the streamgage at Bismarck (station 06342500; table 5). These surveys of the Bismarck reach of the Missouri River were conducted during the flood recession, but shortly after the peak, which occurred on June 25, 2011 (fig. 25). In addition, figure 25 shows that the initial bridge surveys as described in the first three subsections of the "Hydrographic Surveys on the Missouri and Yellowstone Rivers at Selected Bridges" section were conducted on the rising limb of the flood hydrograph.

The hydrographic survey results for the Missouri River through Bismarck are shown by survey sector in figures 26 through 42 . The bed elevations ranged from 1,577 to 1,642 ft. Sand-dune bedforms can be seen throughout the survey area with the larger sand dunes approximately $10 \mathrm{ft}$ high. In shallow sectors of the river, 100-percent coverage was not feasible because of time constraints and changing river stages; consequently, data gaps exist between data swaths as shown throughout the surveyed reach. In addition, navigation between sandbar complexes and small channels was challenging even with high flows; therefore, some of the channel braids contain data gaps, such as those shown in side channels extending from sector 3 into sector 4 (fig. 27) and sector 5 into 6 (fig. 29). Many of the scour holes surveyed were caused by local acceleration of flow around bank structures, such as those found in sector 7 on the left bank (fig. 30), at the edge of sector 8 on the left bank downstream from the West Bismarck Expressway Bridge (fig. 31), in sector 9 on the right bank downstream from Memorial Highway Bridge (fig. 32), in sector 12 on the right bank (fig. 34), in sector 13 on the right bank (fig. 35), in sector 16 on the left bank (fig. 38), and in sector 17 around two bank structures on the left bank (fig. 39). In sector 8 , scour was indicated around sheet piling being put into the river to protect homes on the left bank and also just upstream around other bank-protection structures (fig. 31). Results for sector 10 (fig. 33) show some scour around the piers of a railroad bridge. Figure 34 shows that the river narrows and bends where it approaches the Grant Marsh Bridge; consequently, the converging flowlines produce high velocities (experienced during the survey) and a deeper channel in this area. One of the deepest scour holes surveyed was located where the channel narrows and bends against a once-protected bank, in survey sector 19 (fig. 41). This scour hole's minimum bed elevation of $1,577 \mathrm{ft}$ was the lowest elevation surveyed in the Bismarck reach. Elevations in the channel upstream from the constriction and bend ranged from approximately 1,615 to $1,630 \mathrm{ft}$ due to dune formations, making the scour hole up to $53 \mathrm{ft}$ deep.
Figure 25. Daily mean discharge for the Missouri River at Bismarck, North Dakota, streamgage 06342500, May 15 through August 15, 2011.

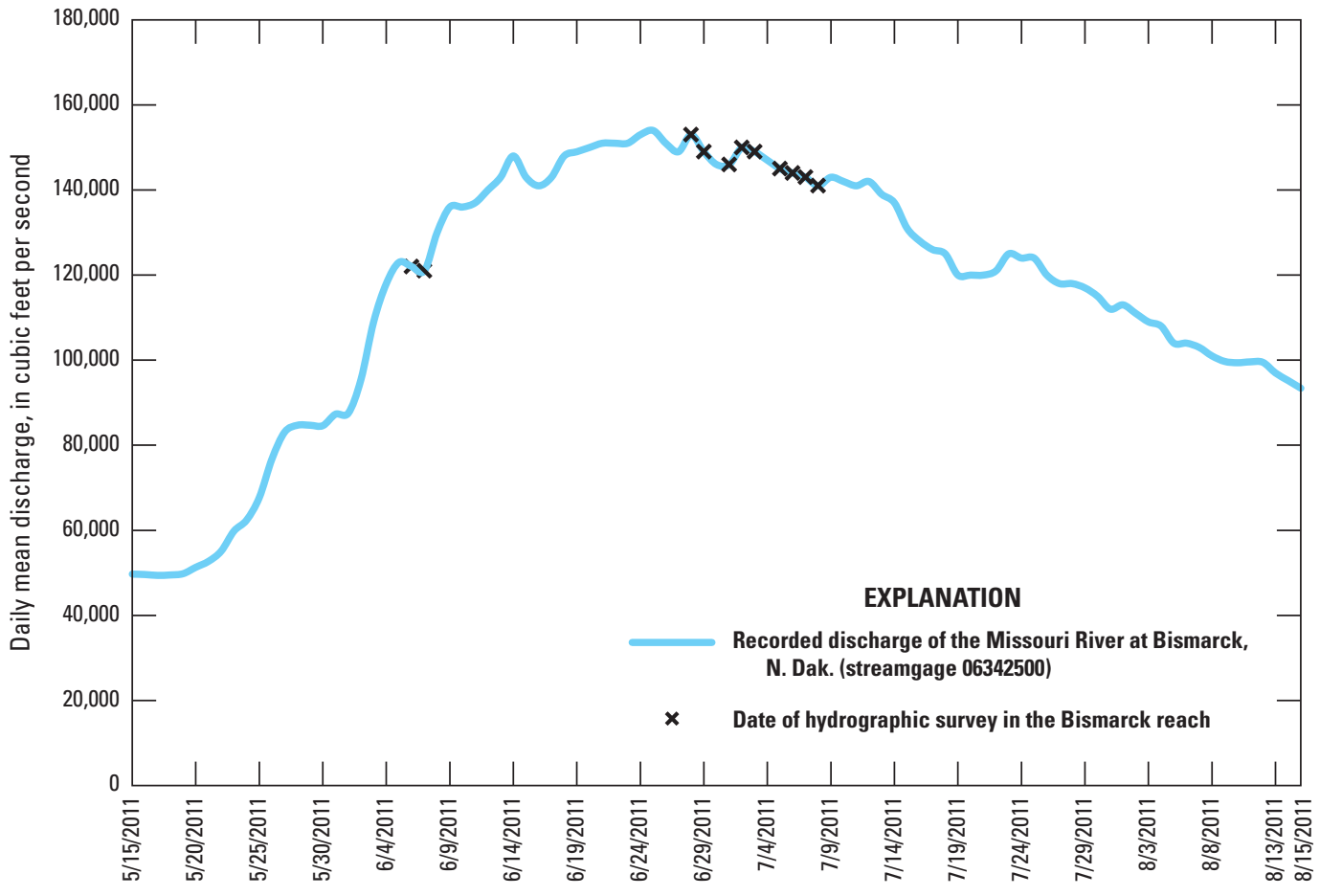

Date 


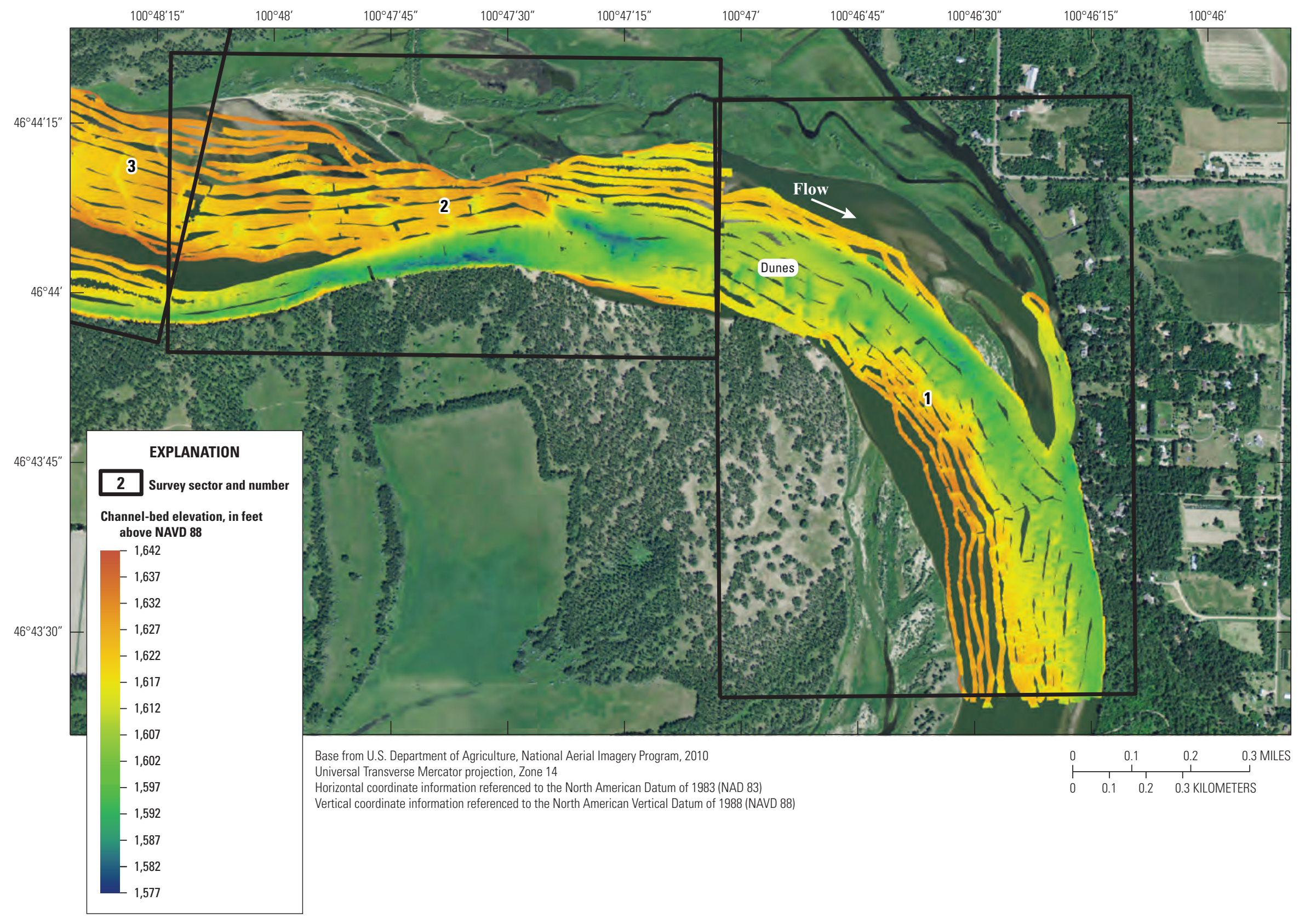

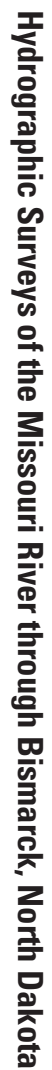

Figure 26. Channel-bed elevations from the Missouri River hydrographic survey of sectors 1 and 2 located south of Bismarck, North Dakota, June 28 and July 2, 2011. 


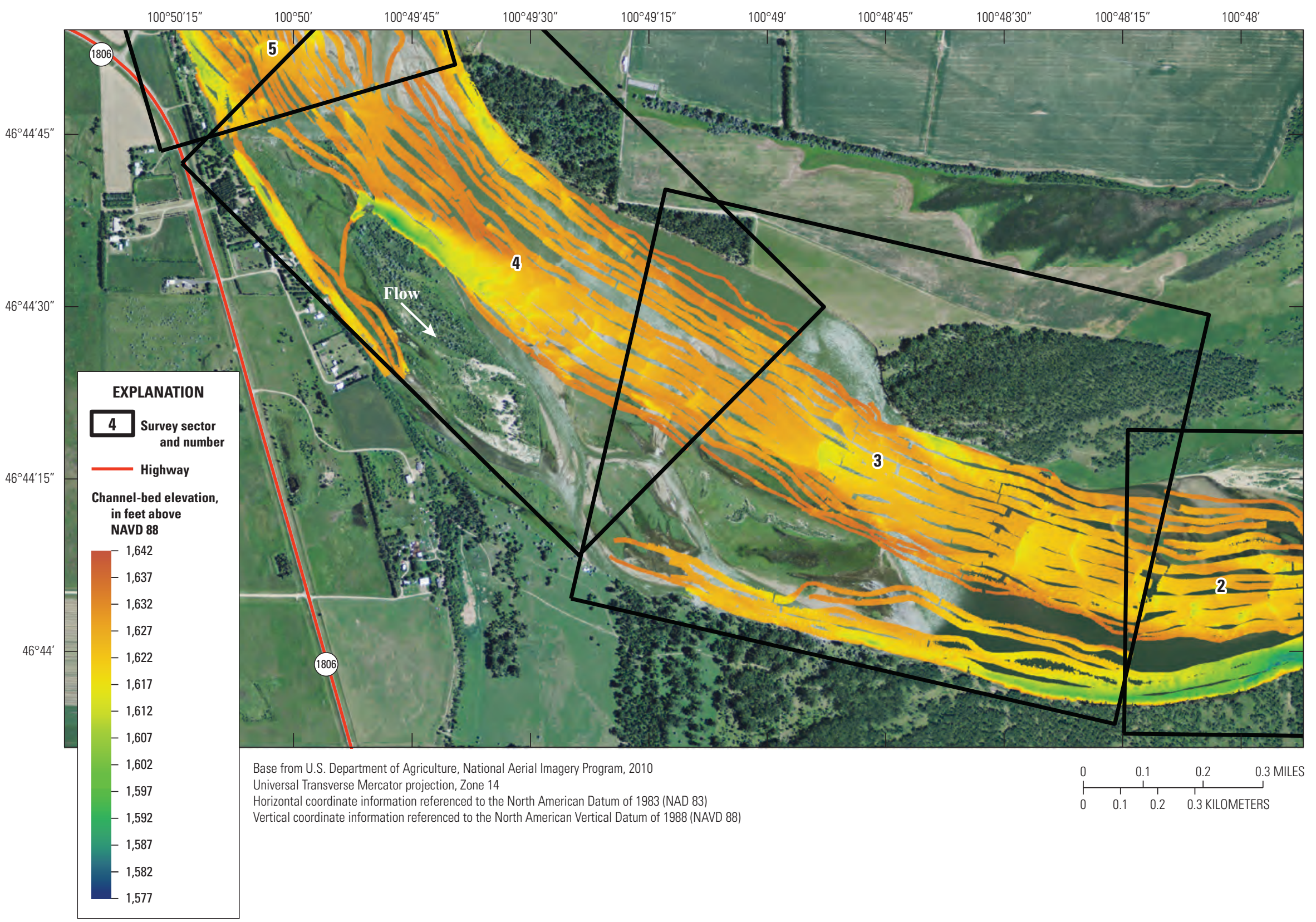

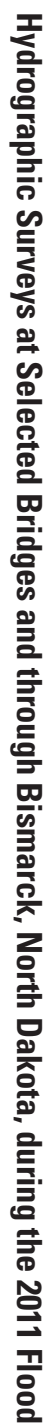

Figure 27. Channel-bed elevations from the Missouri River hydrographic survey of sectors 3 and 4 located south of Bismarck, North Dakota, June 29 and July 1, 2011. 


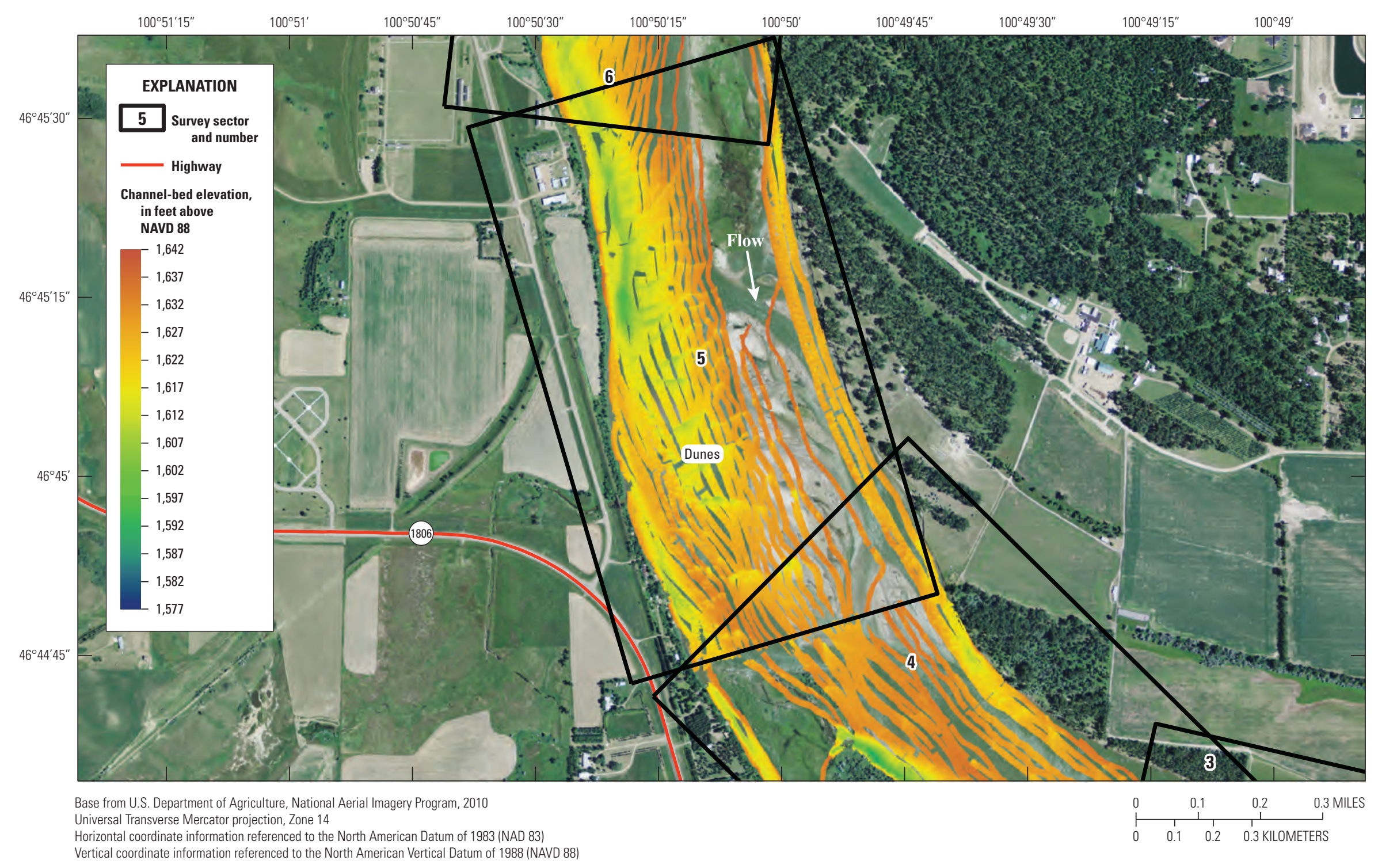

Figure 28. Channel-bed elevations from the Missouri River hydrographic survey of sector 5 located south of Bismarck, North Dakota, June 29, 2011. 


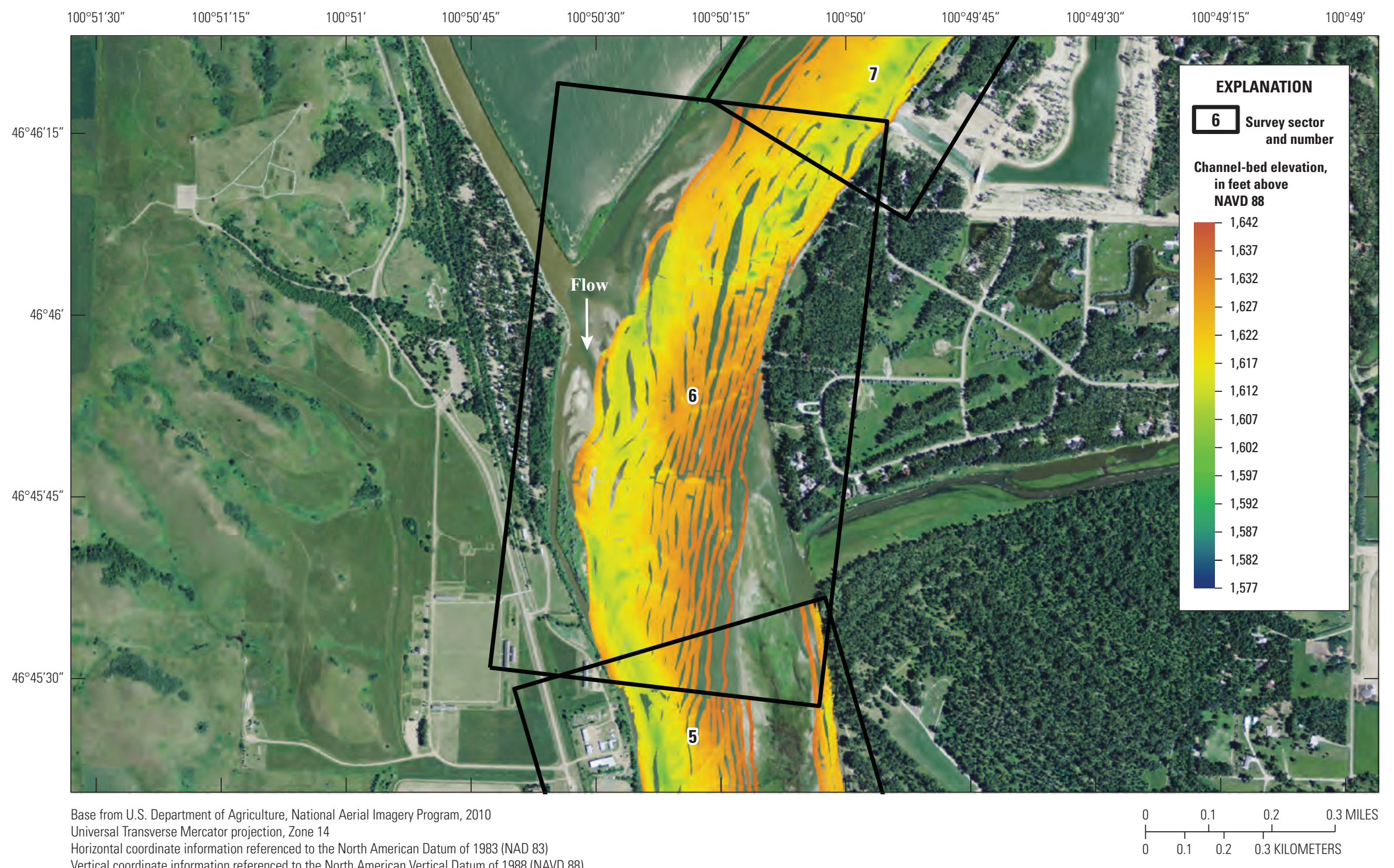

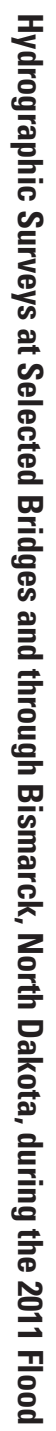

Vertizontal coordinate information referenced to the North American Datum of 1983 (NAD 83)

Figure 29. Channel-bed elevations from the Missouri River hydrographic survey of sector 6 located south of Bismarck, North Dakota, June 29, 2011. 


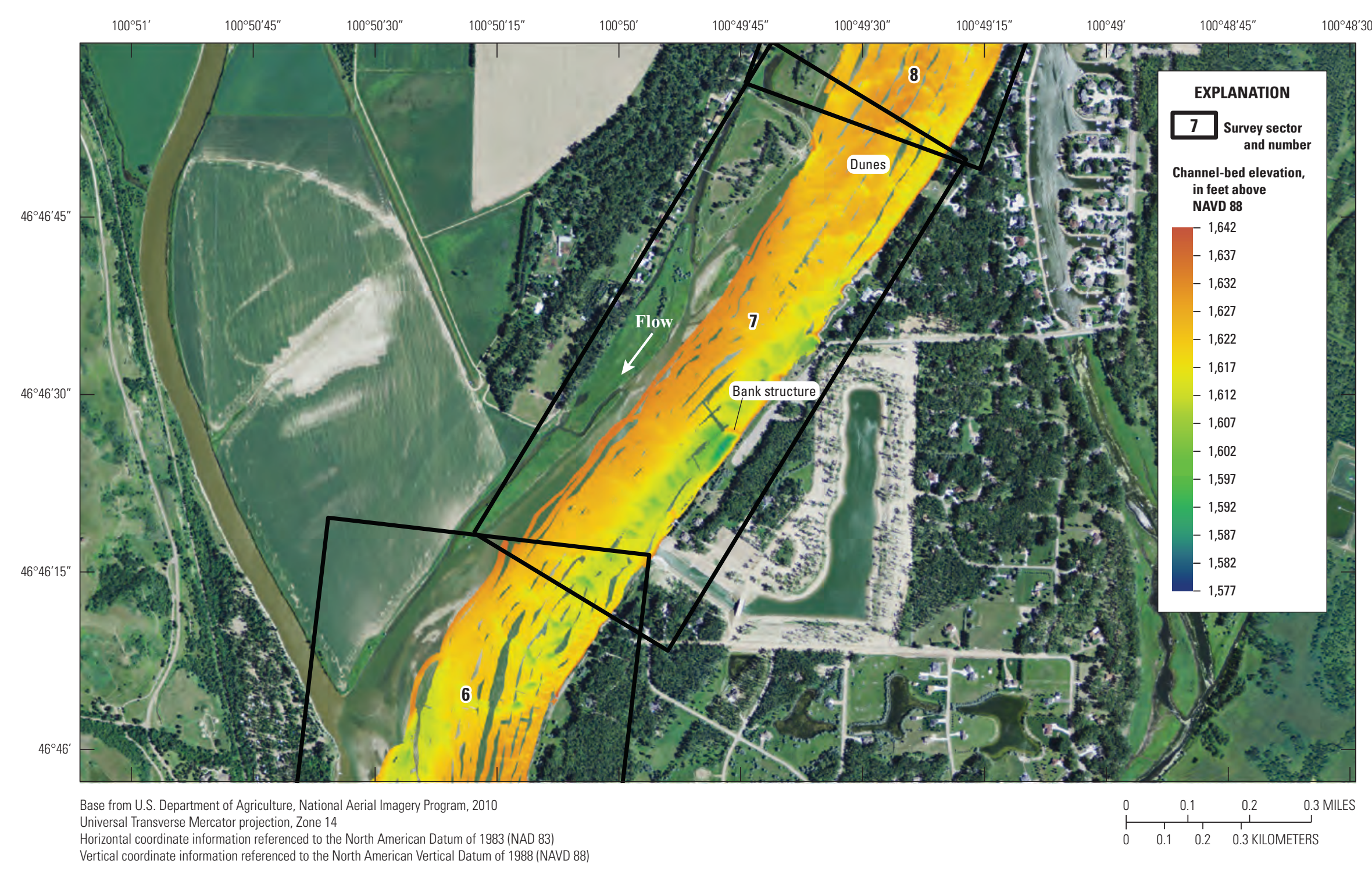

Figure 30. Channel-bed elevations from the Missouri River hydrographic survey of sector 7 located at Bismarck, North Dakota, July 3, 2011. 


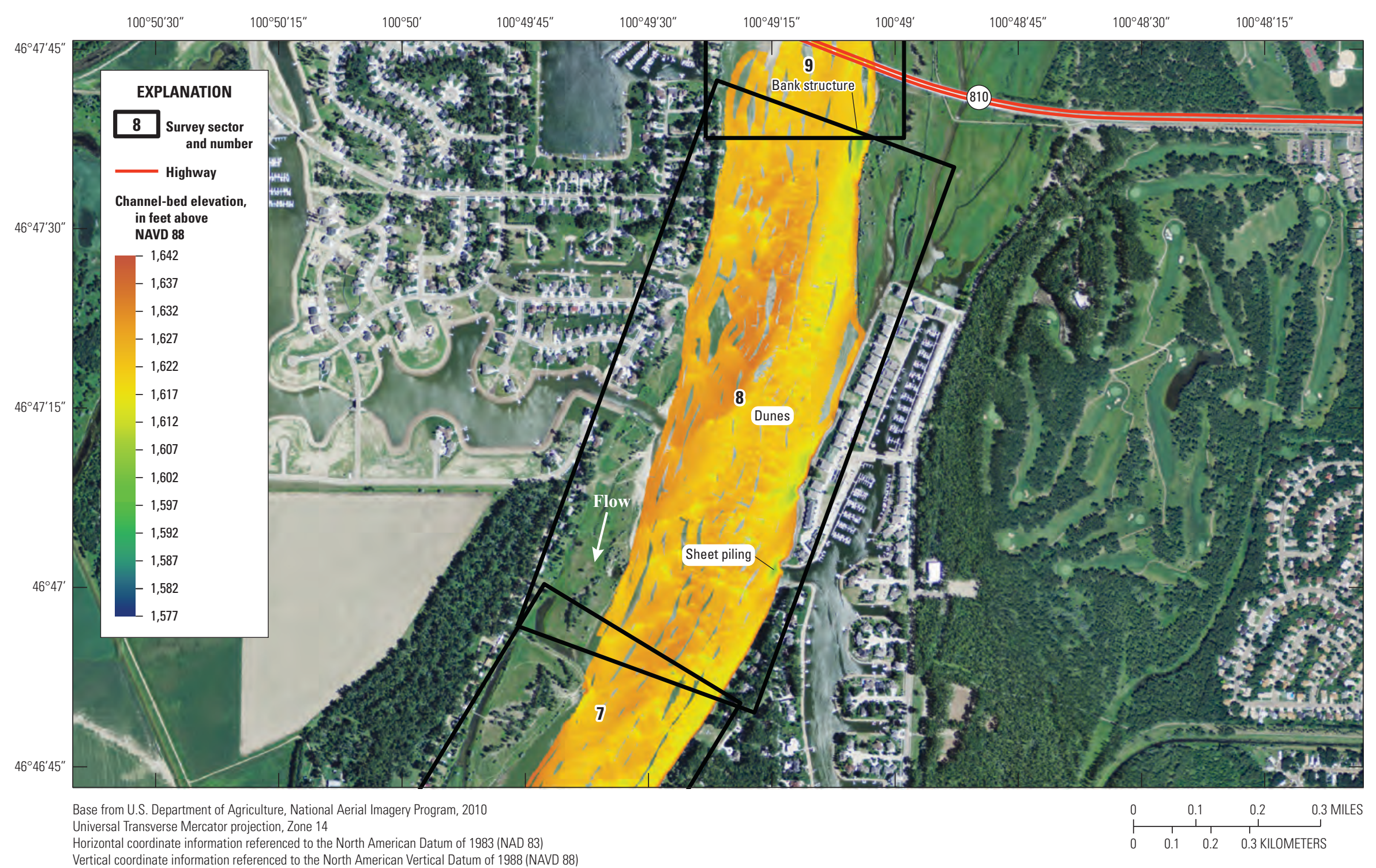

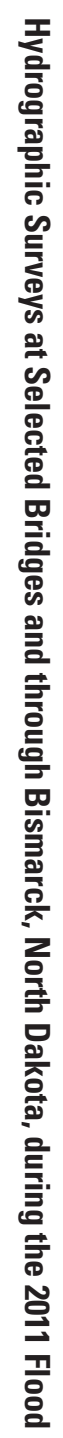

Vertical coordinate information referenced to the North American Vertical Datum of 1988 (NAVD 88)

Figure 31. Channel-bed elevations from the Missouri River hydrographic survey of sector 8 located at Bismarck, North Dakota, July 3, 2011. 


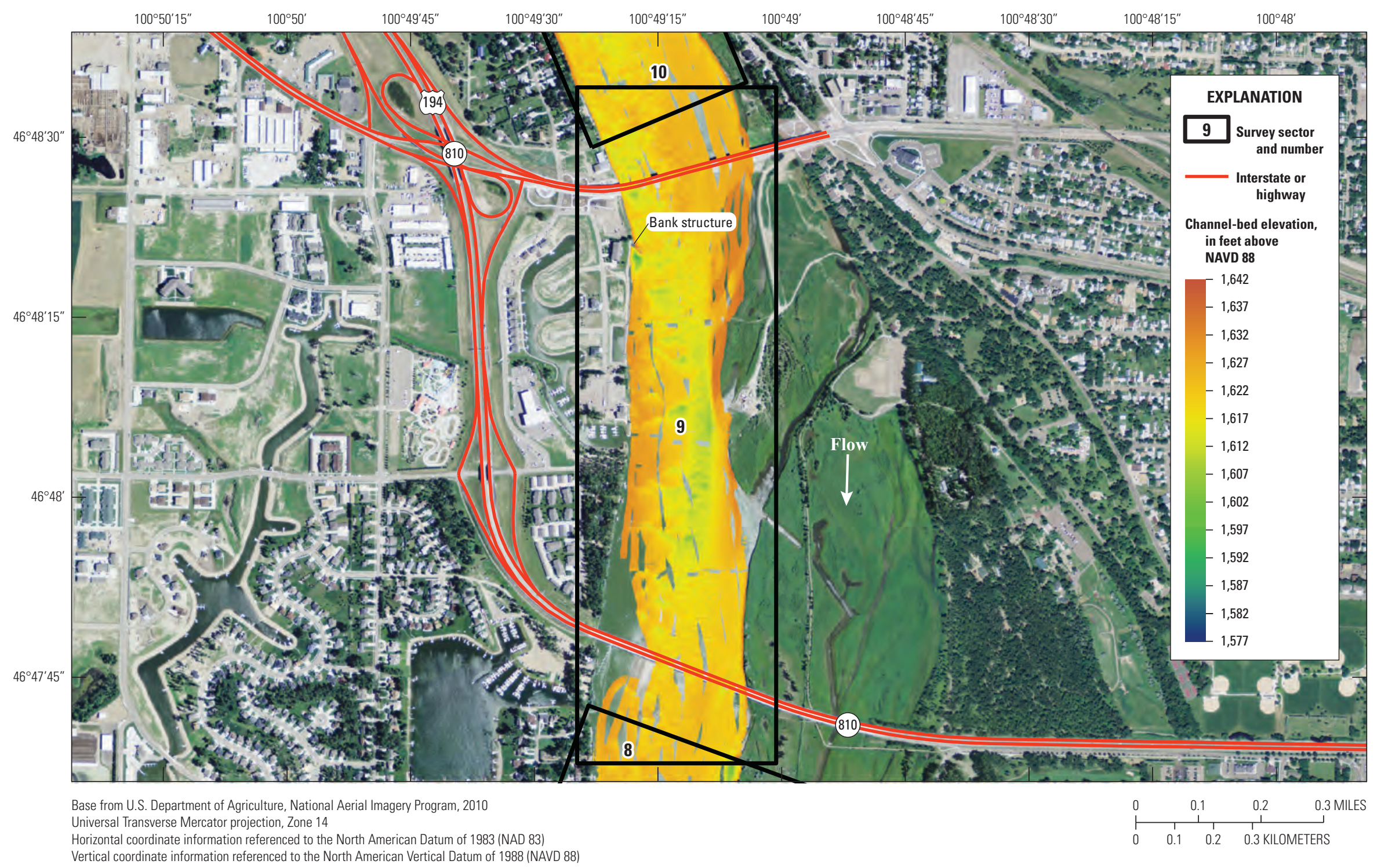

Figure 32. Channel-bed elevations from the Missouri River hydrographic survey of sector 9 located at Bismarck, North Dakota, July 3, 2011. 


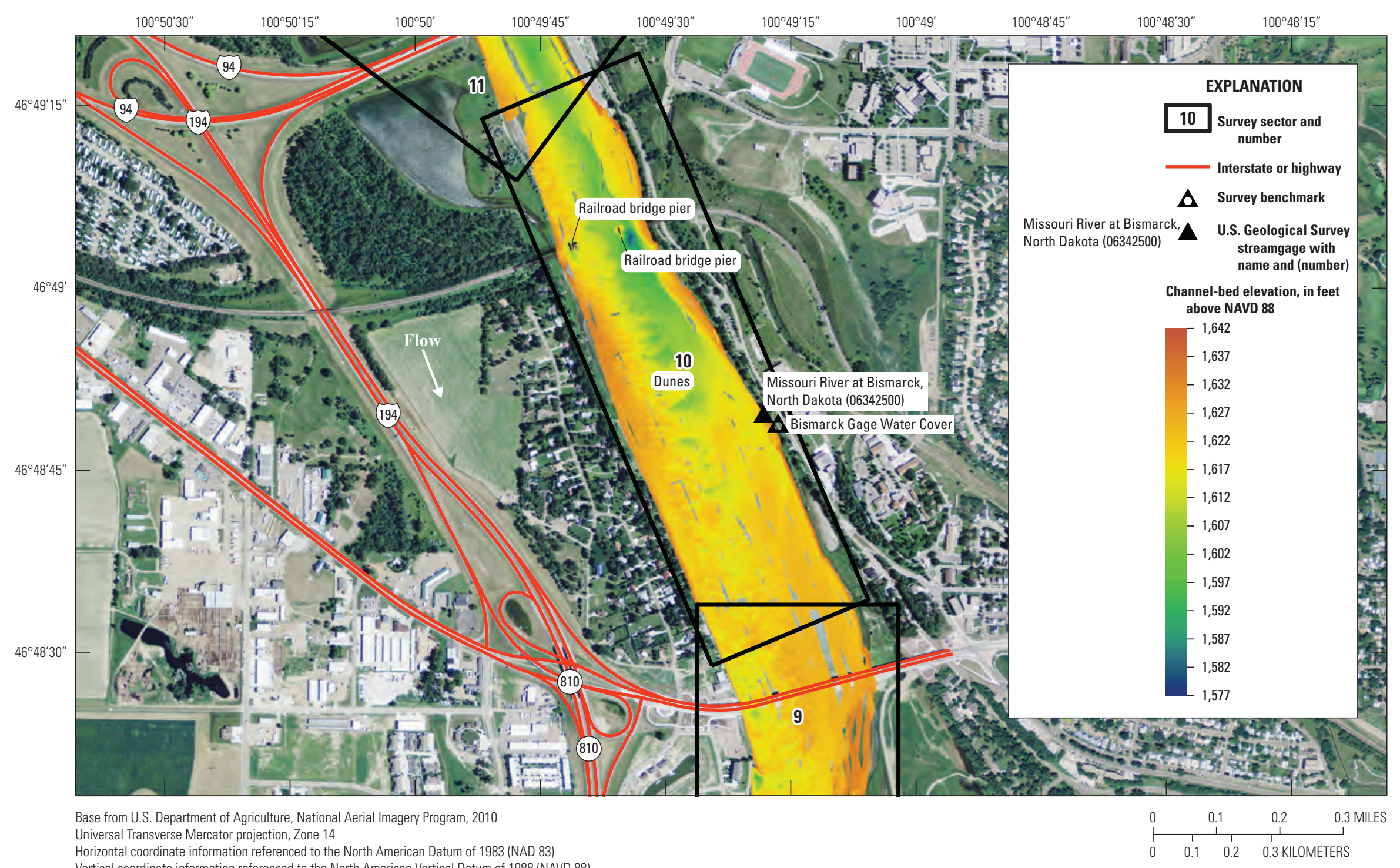

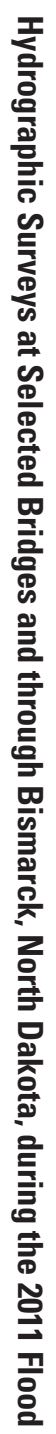

Horizontal coordinate information referenced to the North American Datum of 1983 (NAD 83)

Figure 33. Channel-bed elevations from the Missouri River hydrographic survey of sector 10 located at Bismarck, North Dakota, July 2, 2011. 


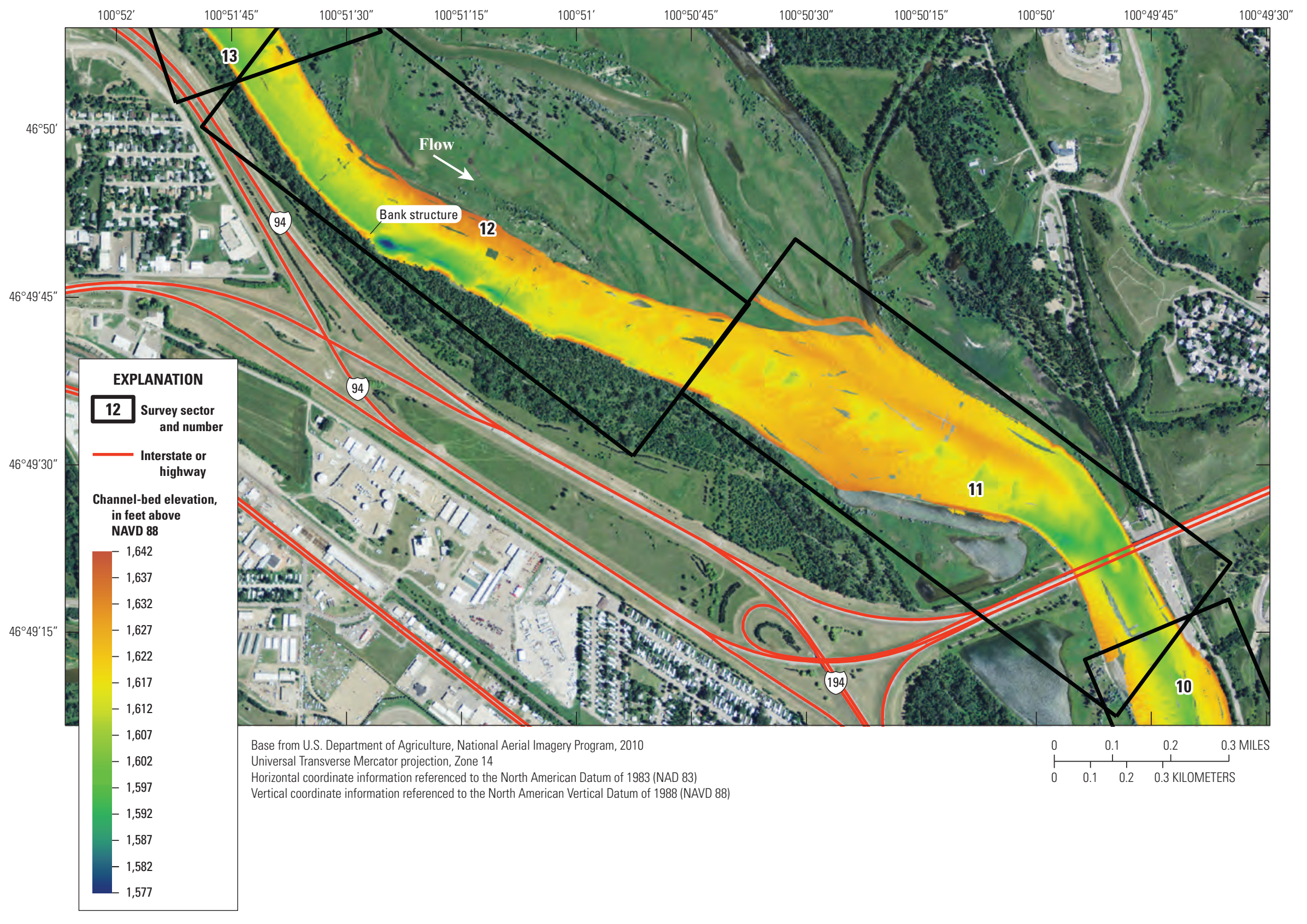

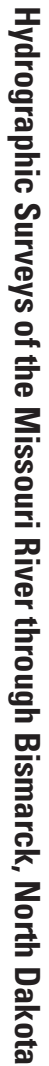

Figure 34. Channel-bed elevations from the Missouri River hydrographic survey of sectors 11 and 12 located at Bismarck, North Dakota, July 5, 2011. 


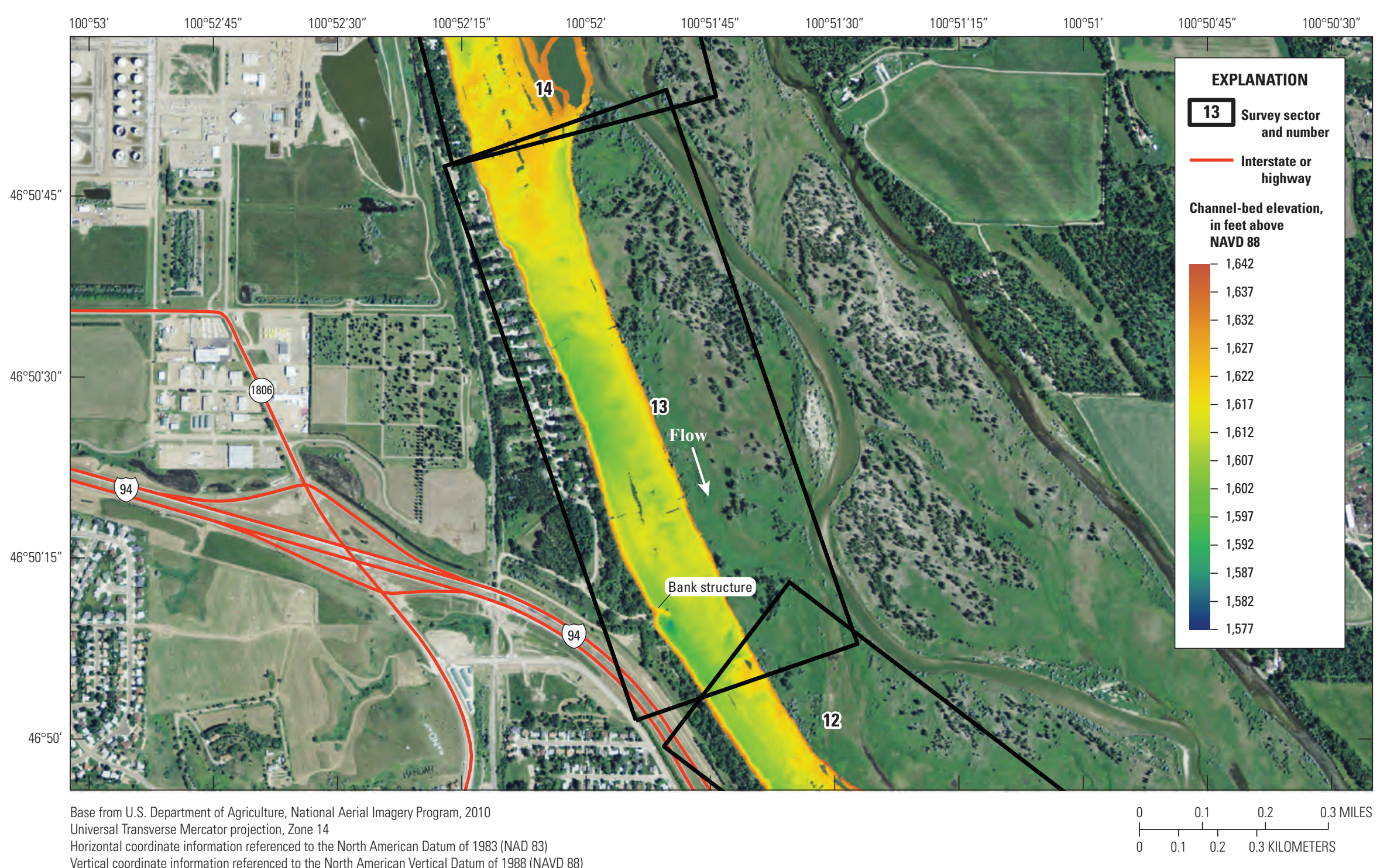

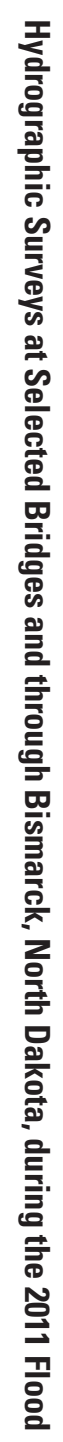

Horizontal coordinate information referenced to the North American Datum of 1983 (NAD 83)

Figure 35. Channel-bed elevations from the Missouri River hydrographic survey of sector 13 located north of Bismarck, North Dakota, July 6, 2011. 


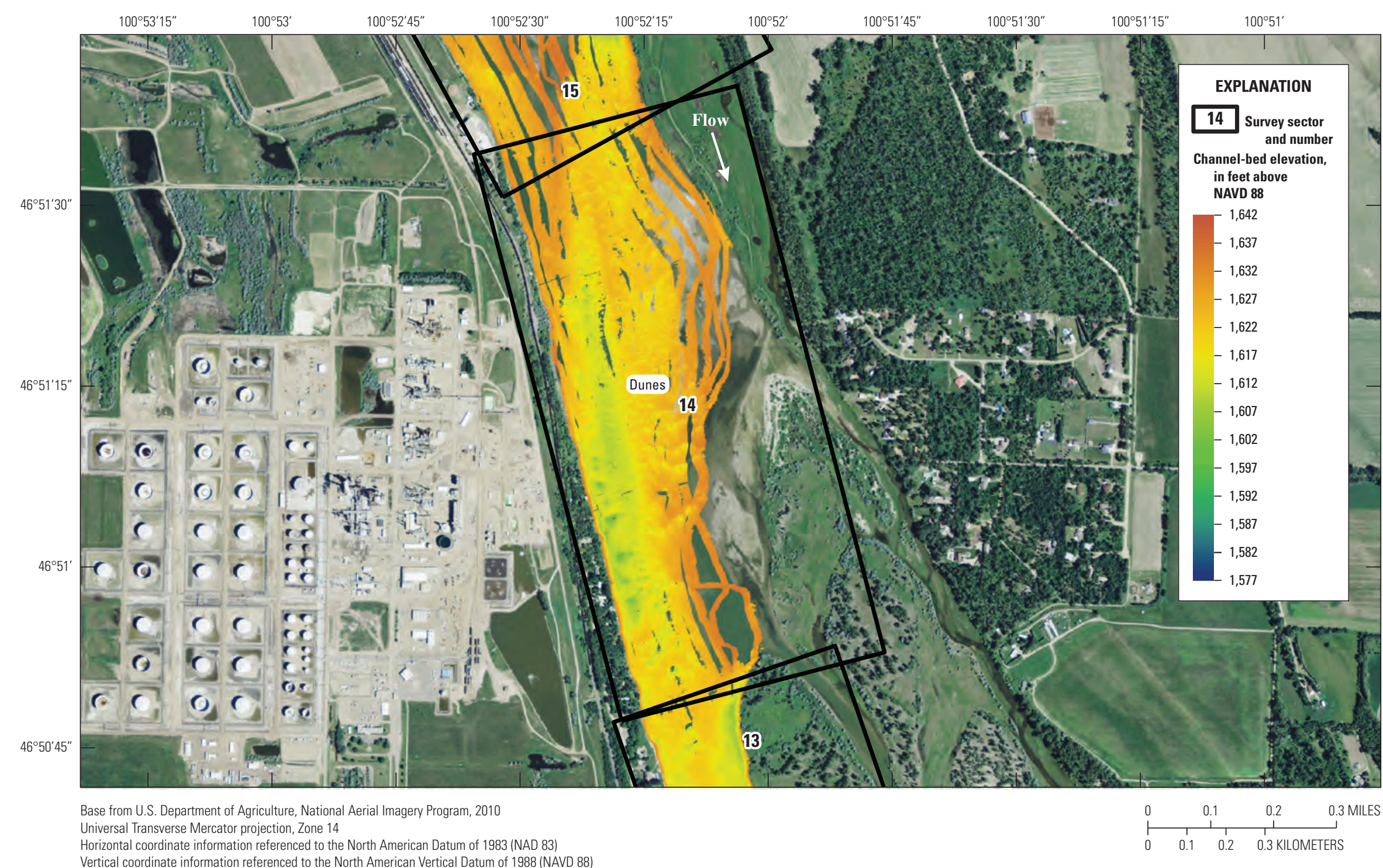

Figure 36. Channel-bed elevations from the Missouri River hydrographic survey of sector 14 located north of Bismarck, North Dakota, July 6, 2011. 


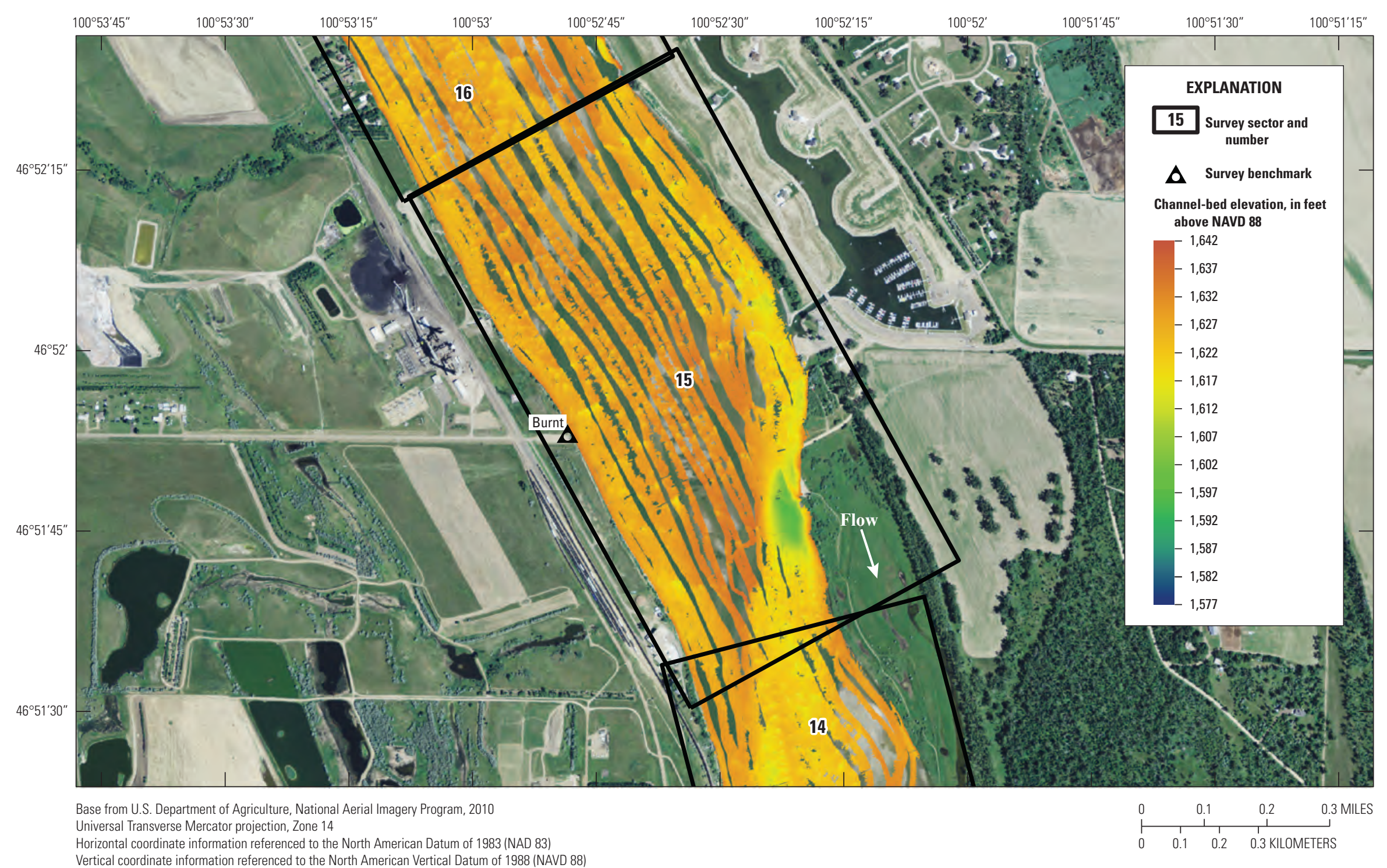

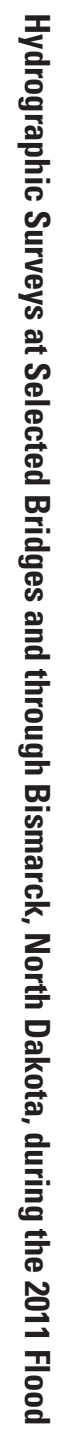

Figure 37. Channel-bed elevations from the Missouri River hydrographic survey of sector 15 located north of Bismarck, North Dakota, July 6-7, 2011. 


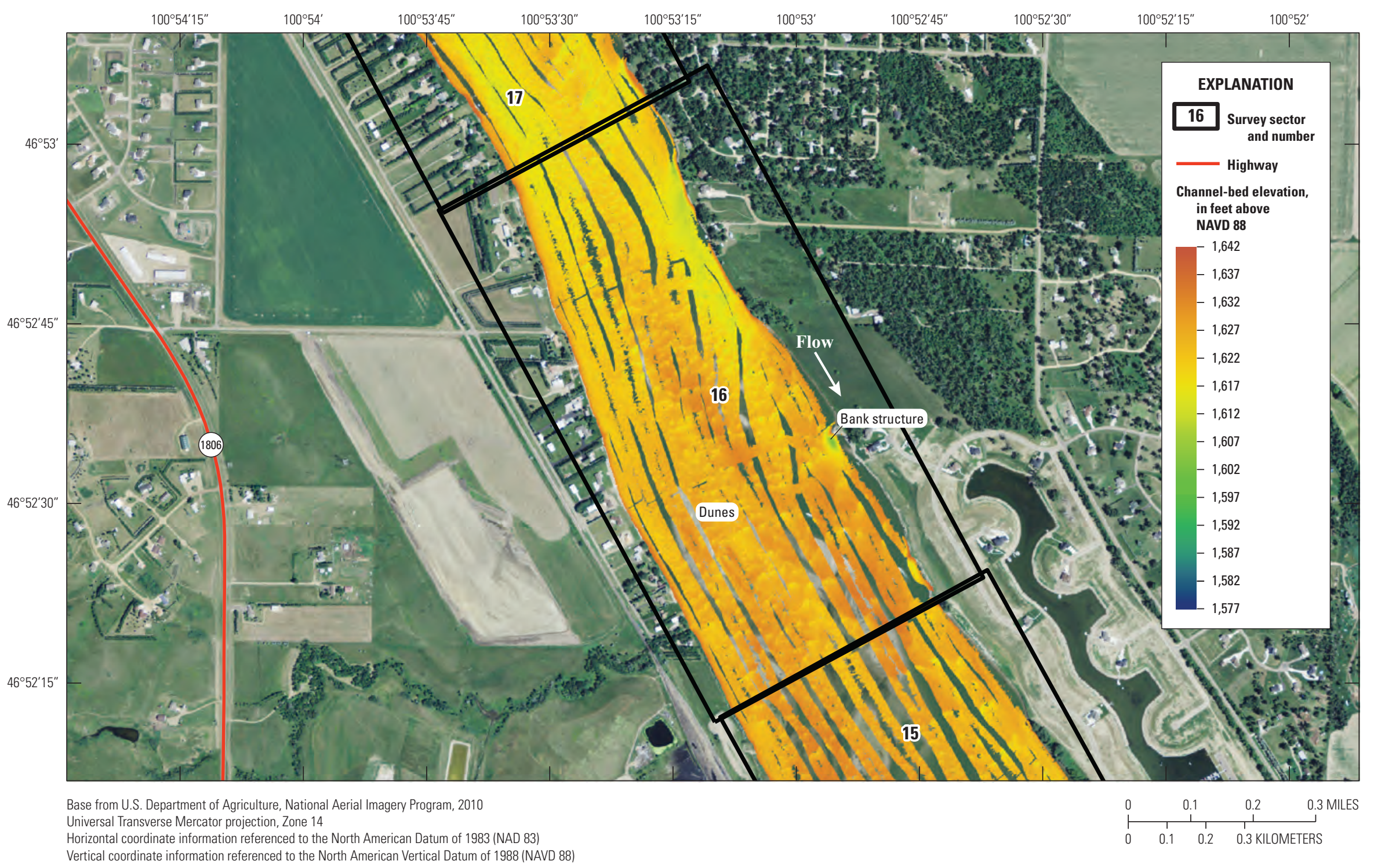

Figure 38. Channel-bed elevations from the Missouri River hydrographic survey of sector 16 located north of Bismarck, North Dakota, July 7, 2011. 


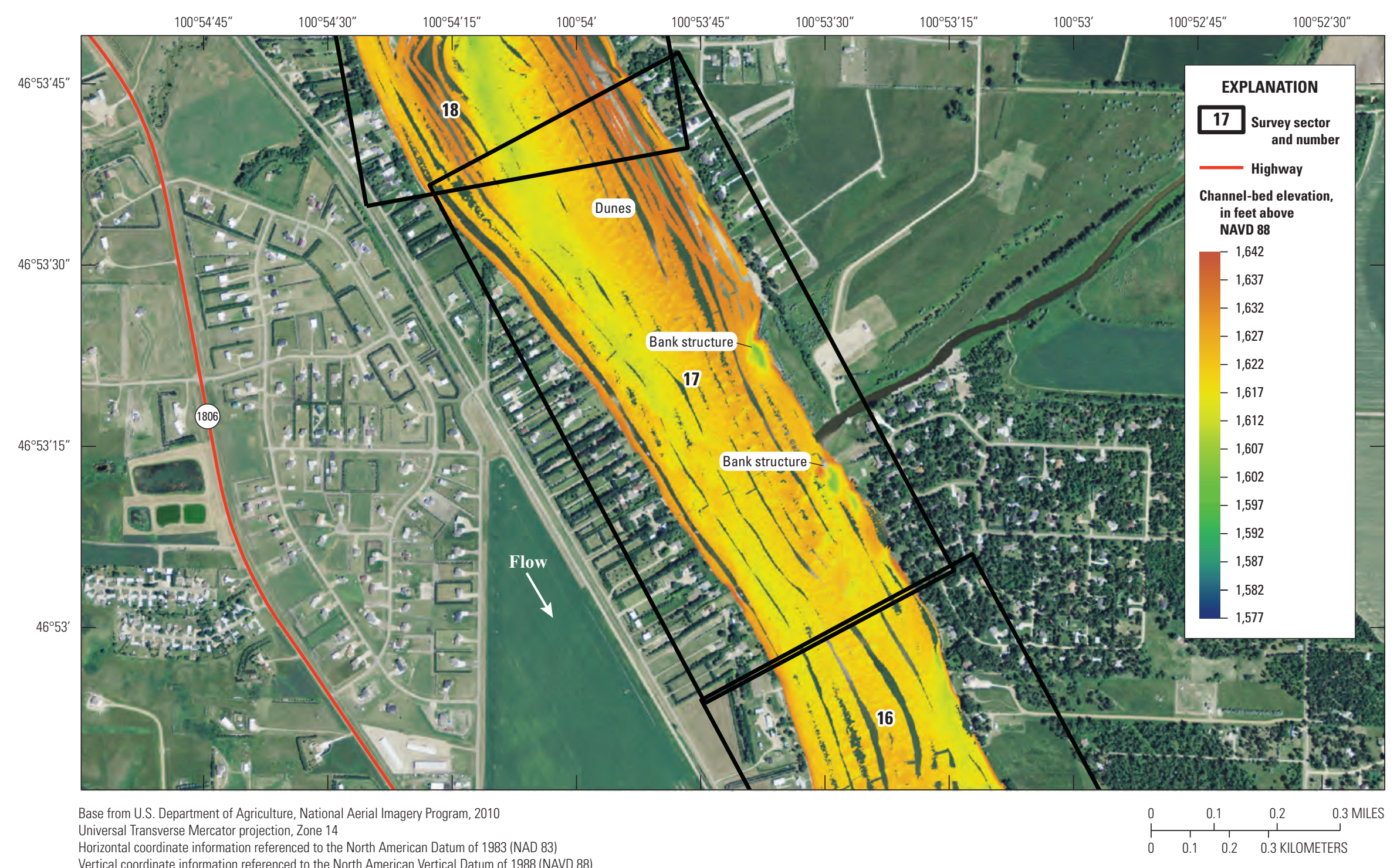

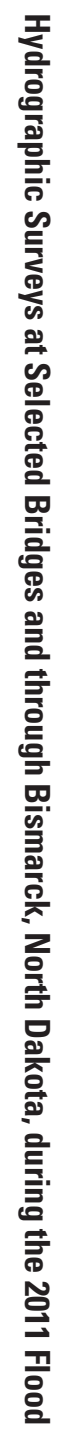

Figure 39. Channel-bed elevations from the Missouri River hydrographic survey of sector 17 located north of Bismarck, North Dakota, July 7, 2011. 


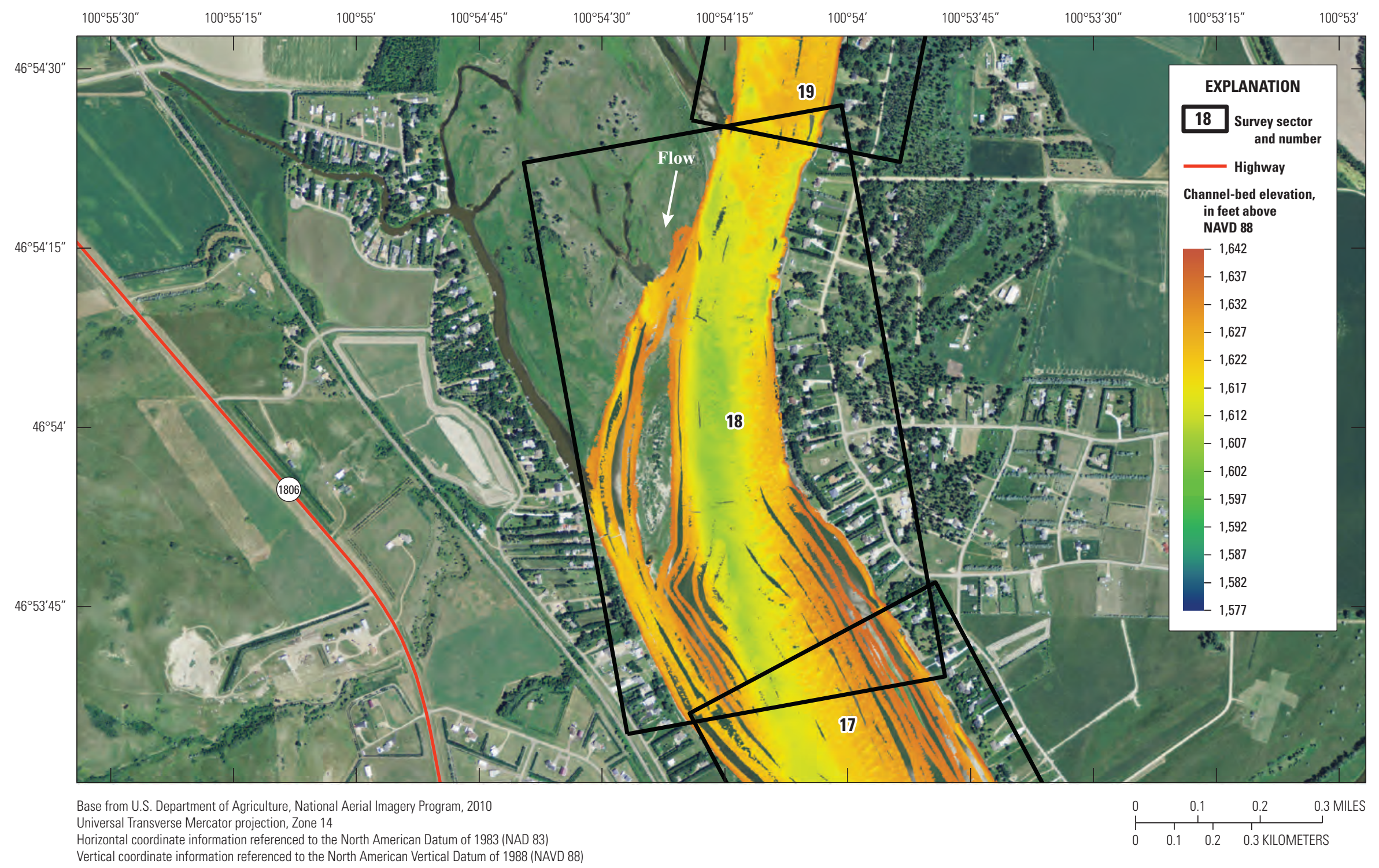

Figure 40. Channel-bed elevations from the Missouri River hydrographic survey of sector 18 located north of Bismarck, North Dakota, July 8, 2011. 


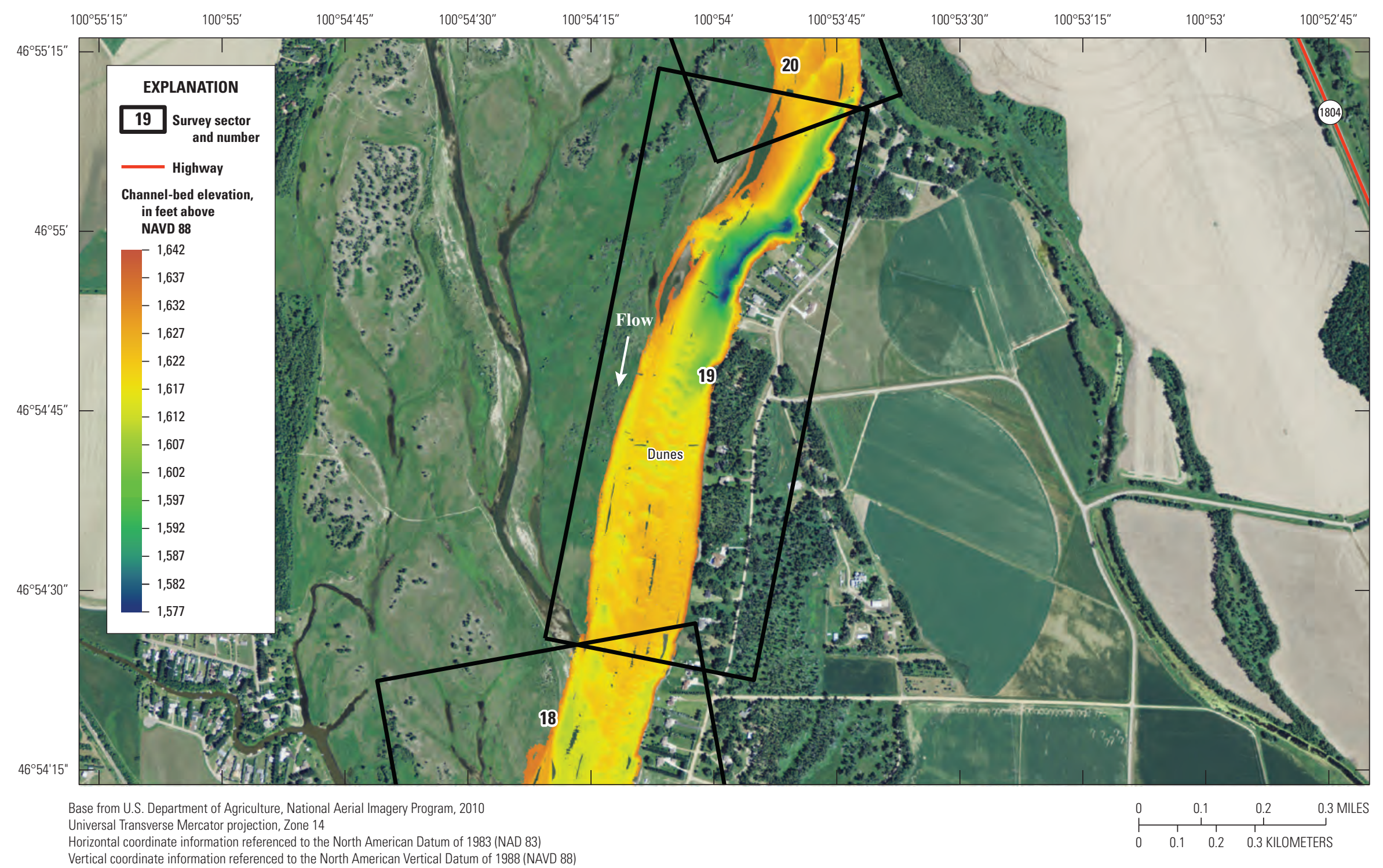

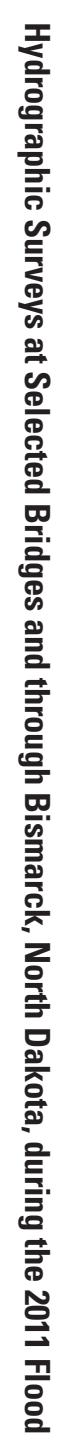

Figure 41. Channel-bed elevations from the Missouri River hydrographic survey of sector 19 located north of Bismarck, North Dakota, July 8, 2011. 


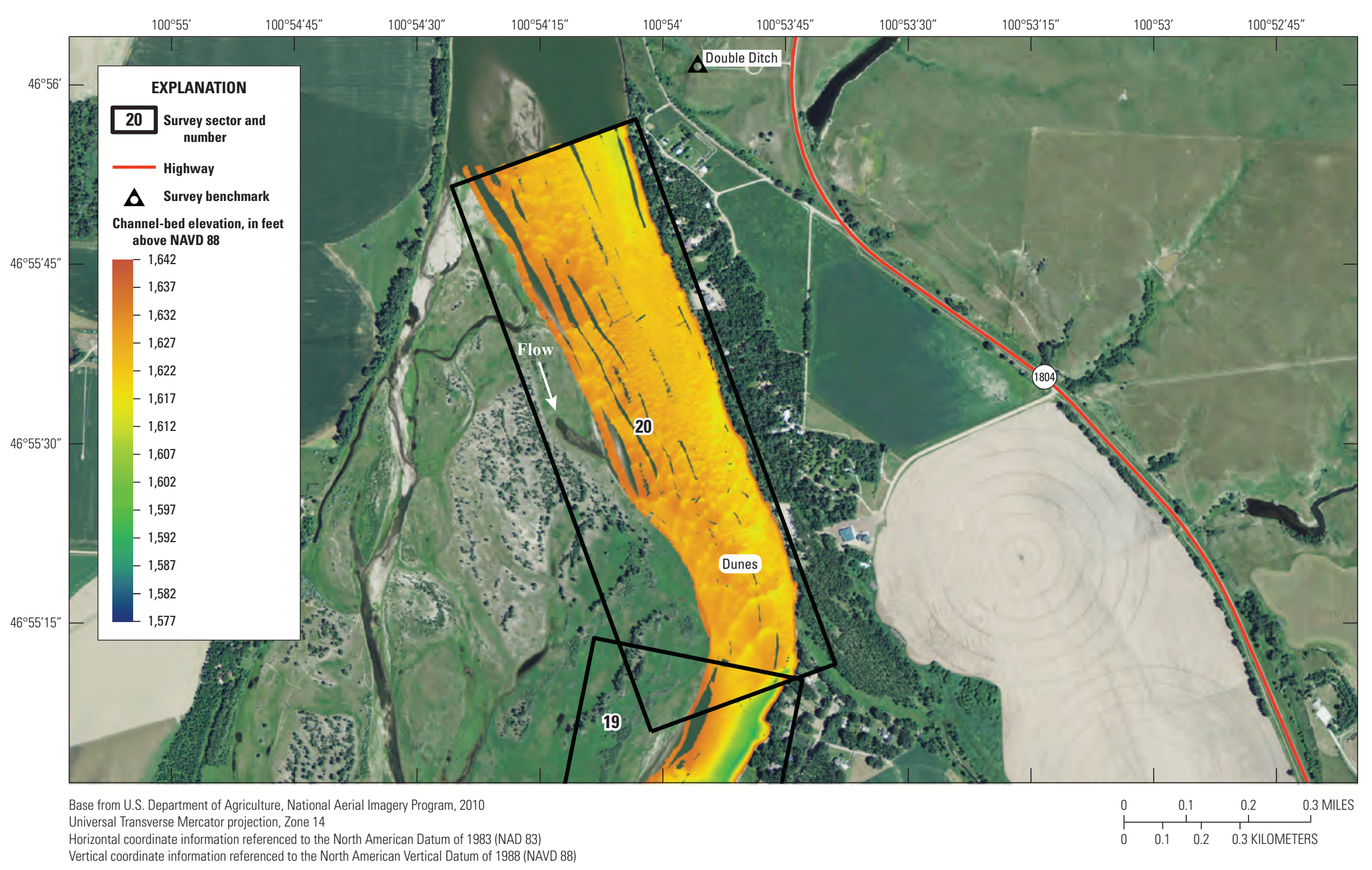

Figure 42. Channel-bed elevations from the Missouri River hydrographic survey of sector 20 located north of Bismarck, North Dakota, July 8, 2011. 


\section{General Results of Hydrographic Surveys during the 2011 Flood on the Missouri and Yellowstone Rivers in North Dakota}

Emergency hydrographic surveys of the Missouri and Yellowstone Rivers were completed successfully with timeliness that aided the North Dakota Department of Transportation's evaluation of the structural integrity of the bridges during the high-flow conditions. In addition, the sustained high flows allowed surveying of the normally shallow channel with a MBES.

In general, results from sequential bridge surveys showed that as discharge increased between the first and second surveys at a given site, there was a general trend that showed channel scour. Locally, some complex responses consisting of scour in some areas and deposition in other areas of the channel were identified (figs. 11, 14, 17, and 20). Scour around bridge piers was complex in response to the increase in flow between the two surveys. Additional surveys prior to and following the flood could have provided even more information about the dynamics of the river channel and the manner in which the bed changed as a result of increased flows and in association with river structures. Results of the survey of the 18-mile reach through Bismarck, N. Dak., showed scour occurred either around river structures or where there were changes in the river-channel geometry, such as tight bends and channel narrowing.

These high-resolution hydrographic datasets could be used for further analysis of streambeds by computer modeling and compared with future hydrographic surveys to evaluate change over time. The data also will serve as a lasting record of the Missouri and Yellowstone Rivers bed configurations during their historic 2011 flood.

The data collected during the surveys described in this report are provided in two different formats with all coordinates referenced to the North American Datum of 1983 (Continuously Operating Reference Stations 1996) [NAD83(CORS96)], using the Universal Transverse Mercator (UTM) projection. The first format is an ASCII text document, which is comma-delimited with a header row defining three columns- $x, y$, and $z$. The name of each text file identifies the bridge site or survey sector where the data were collected, as well as the UTM zone, coordinate units, and grid spacing used when reducing the dataset. The second data format is a CARIS Spatial Archive ${ }^{\mathrm{TM}}\left(\mathrm{CSAR}^{\mathrm{TM}}\right.$, .csar) grid file. This opensource file format can be opened with CARIS Easy View ${ }^{\mathrm{TM}} 4.0$ software [freely available for downloading (CARIS, 2013b)] or any other software that supports the file format. Detailed information describing each dataset is provided in a metadata file associated with the dataset by the same root file name.

\section{Summary}

The U.S. Geological Survey (USGS), in cooperation with the North Dakota Department of Transportation and the North Dakota State Water Commission, conducted hydrographic surveys centered on six Missouri River bridges, one Yellowstone River bridge, and the reach of the Missouri River that flows through Bismarck, N. Dak., during the flood of 2011. The surveyed area at each bridge site extended 820 feet upstream from the bridge to 820 feet downstream from the bridge. Bridges surveyed are located near the cities of Cartwright, Buford, Williston, Washburn, and Bismarck, N. Dak. The surveyed reach through Bismarck consisted of 18 miles, from the University of Mary (Sibley Bend) to Double Ditch Indian Village State historic site, of the main channel wherever depth was sufficient. These hydrographic surveys were conducted using a high-resolution multibeam sonar mapping system, RESON SeaBat ${ }^{\mathrm{TM}} 7125$. All surveys were completed during June 6-9 and June 28-July 9, 2011. Emergency surveys of the Missouri River and Yellowstone Rivers were conducted successfully and in a timely manner to aid the North Dakota Department of Transportation in evaluating the safety of the bridges under high-flow conditions. In addition, the sustained high flows made surveying a large section of the normally shallow channel with a multibeam echosounder feasible.

In general, results from sequential bridge surveys show that as discharge increased between the first and second surveys at a given site, there was a general trend of channel scour. Locally, scour occurred in some areas of the channel and deposition in other areas of the channel. Similarly, scour around bridge piers was complex in response to the increase in flow between the two surveys. Scour holes surveyed at bridge piers ranged up to $19 \mathrm{ft}$. Results for the survey area extending through Bismarck showed that, in general, scour occurred around river structures or where there were changes in the river channel geometry, such as tight bends and channel narrowing. An extreme example of this was documented in survey sector 19 upstream from Bismarck where the river narrowed into a bend and the scour hole on the outside of the bend was up to $53 \mathrm{ft}$ in depth.

The data collected during the surveys are provided in two different file formats: comma-delimited text files and CARIS Spatial Archive ${ }^{\mathrm{TM}}\left(\mathrm{CSAR}^{\mathrm{TM}}\right.$, .csar) files. The datasets will serve as a lasting record of the Missouri and Yellowstone Rivers bed configurations during the historic 2011 flood. 


\section{References Cited}

Applanix Corporation, 2006, POS MVTM V4 user guide, rev. D: Richmond Hill, Ontario, Canada, Applanix Corp., PUBS-MAN-000513, 369 p.

Berkas, W.R., 1995, Transport and sources of sediment in the Missouri River between Garrison Dam and the headwaters of Lake Oahe, North Dakota, May 1988 through April 1991: U.S. Geological Survey Water-Resources Investigations Report 95-4087, 26 p. (Also available online at http:// nd.water.usgs.gov/pubs/wri/wri954087/index.html.)

CARIS, 2013a, CARIS BASE Editor ${ }^{\mathrm{TM}}$ reference guide: Fredericton, New Brunswick, Canada, CARIS, 894 p.

CARIS, 2013b, CARIS Easy View ${ }^{\mathrm{TM}}$ : Fredericton, New Brunswick, Canada, CARIS, accessed March 8, 2013, at http://www.caris.com/products/easy-view/.

CARIS, 2012a, CARIS HIPS and SIPS ${ }^{\text {TM: }}$ Fredericton, New Brunswick, Canada, CARIS, accessed May 11, 2012, at http://www.caris.com/products/hips-sips/.

CARIS, 2012b, CARIS BASE editor ${ }^{\mathrm{TM}}$ : Fredericton, New Brunswick, Canada, CARIS, accessed May 11, 2012, at http://www.caris.com/products/bathydatabase/base-editor/.

CARIS, 2011, Caris HIPS and SIPS ${ }^{\mathrm{TM}} 7.1$ professional users guide: Fredericton, New Brunswick, Canada, CARIS, $474 \mathrm{p}$.

Esri, 2012a, World terrain base: Redlands, Calif., Esri, accessed October 2012, at http://www.arcgis.com/home/ item.html?id=c61ad8ab017d49e1a82f580ee1298931.

Esri, 2012b, ArcGIS 10.0: Redlands, Calif., Esri, accessed June 2012, at http://www.esri.com/.

Federal Emergency Management Agency, 2011, Emergency declaration expanded to address Missouri River flooding: Federal Emergency Management Agency, News Release 3318-005, May 28, 2011, accessed February 13, 2012, at http://www.fema.gov/news-release/emergency-declarationexpanded-address-missouri-river-flooding.

Federal Highway Administration, 2011, Scour monitoring and instrumentation, chap. 9 of Bridge scour and stream instability countermeasures: Experience, selection, and design guidance ( $3 \mathrm{~d}$ ed.): Washington, D.C., U.S. Department of Transportation, Federal Highway Administration, accessed May 20, 2001, at http://www.fhwa.dot.gov/engineering/ hydraulics/pubs/09111/page09.cfm.
Huizinga, R.J., 2010, Bathymetric surveys at highway bridges crossing the Missouri River in Kansas City, Missouri, using a multibeam echo sounder, 2010: U.S. Geological Survey Scientific Investigations Report 2010-5207, 61 p.

Huizinga, R.J., 2011, Bathymetric surveys at highway bridges crossing the Missouri and Mississippi Rivers near St. Louis, Missouri, 2010: U.S. Geological Survey Scientific Investigations Report 2011-5170, 75 p. (Also available online at http://pubs.usgs.gov/sir/2011/5170/.)

Huizinga, R.J., Elliott, C.M., and Jacobson, R.B., 2010, Bathymetric and velocimetric survey and assessment of habitat for pallid sturgeon on the Mississippi River in the vicinity of the proposed Interstate 70 Bridge at St. Louis, Missouri: U.S. Geological Survey Scientific Investigations Report 2010-5017, 28 p. (Also available online at http://pubs.usgs. gov/sir/2010/5017/.)

HYPACK, Inc., 2007a, HYPACK® user's manual 1/07: Middletown, Conn., HYPACK, 991 p.

HYPACK, Inc., 2007b, HYSWEEP® user's manual 6/07: Middletown, Conn., HYPACK, 148 p.

Landers, M.N., and Mueller, D.S., 1996, Channel scour at bridges in the United States: Federal Highway Administration Report FHWA-RD-95-184, 140 p.

Leopold, L.B., Wolman, M.G., and Miller, J.P., 1964, Fluvial processes in geomorphology: New York, Dover Publications, $227 \mathrm{p}$.

National Geodetic Survey, 2012a, OPUS - Online Positioning User Service: Silver Spring, Md., National Geodetic Survey, accessed May 11, 2012, at http://www.ngs.noaa.gov/OPUS/.

National Geodetic Survey, 2012b, Continuously Operating Reference Station (CORS): Silver Spring, Md., National Geodetic Survey, accessed May 11, 2012, at http://www.ngs. noaa.gov/CORS/.

National Geodetic Survey, 2012c, Datasheet for control station designated Sibley 2, Burleigh County, N. Dak., with permanent identifier AE1790: Silver Spring, Md., National Geodetic Survey data sheet, accessed July 3, 2012, at http:// www.ngs.noaa.gov/cgi-bin/ds_pid.prl/1.

National Weather Service, 2011, Missouri river flooding 2011: Silver Spring, Md., National Weather Service, accessed July 3, 2012, at http://www.crh.noaa.gov/crh/?n=mo-riverflooding-2011.

RESON, Inc, 2001, Sonar theory: Goleta, Calif. RESON, 40 p. 
RESON, Inc., 2006, SeaBat ${ }^{\mathrm{TM}} 7125$ high-resolution multibeam echosounder system, Version B066 080218/A4: Goleta, Calif., RESON, 2 p.

RESON, Inc., 2008, SeaBat ${ }^{\mathrm{TM}} 7125$ high-resolution multibeam echosounder system operator's manual, Version 6.01: Goleta, Calif., RESON, 100 p.

Rugg, D.J., 2004, Creating FGDC and NBII metadata with Metavist 2005: St. Paul, Minn., U.S. Department of Agriculture, Forest Service General Technical Report NC-255, $30 \mathrm{p}$.

U.S. Army Corps of Engineers, 2011, Missouri River mainstem reservoir system, 2011 flood regulation, 1 October 2011: Washington, D.C., U.S. Army Corp of Engineers slide set, accessed February 13, 2012, at http://www.nwd-mr.usace.army.mil/rcc/reports/pdfs/ MissouriRiverFloodingUpdate.pdf.

U.S. Department of Agriculture, National Aerial Imagery Program, 2010, USDA-FS-APFO Digital Ortho Mosaics: Salt Lake City, Utah, U.S. Department of Agriculture, Farm Service Agency, Aerial Photography Field Office, accessed June 2011, at $h t t p: / / w w w . f s a . u s d a . g o v / F S A / a p f o a p p ?$ area $=h$ ome\&subject $=$ maps\&topic $=$ arc .

U.S. Geological Survey, 2012, National Water Information System: U.S. Geological Survey database, accessed March 2012, at http://waterdata.usgs.gov/nwis/. 


\section{Glossary}

display depth range Setting for the RESON SeaBat ${ }^{\mathrm{TM}} 7125$ that sets the maximum distance that the sonar will display. Depth range partially controls ping rate by estimating time of return for one sonar ping before a second sonar ping can be transmitted. The RESON SeaBat ${ }^{\mathrm{TM}} 7125$ has a range setting from 16.4 to 984.25 feet.

\section{fixed Global Positioning System/Global Navigation Satellite System (GPS/GNSS) solution Position determined by the GNSS rover with information from five or more GNSS satellites and base-station correction information with all carrier-phase ambiguities solved and the estimated position error below a set tolerance.}

latency The time lapse between two different datasets. In multibeam hydrographic surveying, this is typically the time difference between sounding data and positioning data.

maximum ping rate Setting for the RESON SeaBat ${ }^{\mathrm{TM}} 7125$ that limits the number of pings per second $(\mathrm{p} / \mathrm{s})$, making it lower than the standard ping rate for that range setting. The RESON SeaBat ${ }^{\mathrm{TM}} 7125$ has a range from $\mathrm{OFF}$ to $50 \mathrm{p} / \mathrm{s}$. Maximum ping rate might be increased for additional data collection over areas of interest or decreased to limit redundant data.

outside beams The beams that are formed from a sonar ping on the outer edge of the swath. The sounding from these beams are often edited out of multibeam data because of the tendency of these data to be inconsistent with other data as a result of the increased incident angle and higher energy loss from absorption and spreading over the greater distance.

piezo-electric ceramics Ceramic material with piezoelectric (electric resulting from pressure) characteristics as well as reverse piezoelectric effects (internal generation of a mechanical strain resulting from an applied electric field). Reverse piezoelectric effects are utilized to produce sound waves by applying a voltage to the ceramic which responds with oscillation. The frequency of this oscillation depends on the frequency of the input signal and the characteristics and design of the ceramic material. This oscillation causes a series of compressions and rarefactions in the surrounding water-a sound pressure wave (RESON, 2001).

pitch Rotation of the boat about the acrosstrack dimension.

pulse length Setting for the RESON SeaBat $^{\mathrm{TM}} 7125$ that controls the length of time the sonar signal is transmitted. Pulse length on the RESON SeaBat ${ }^{\mathrm{TM}} 7125$ can range from 10 to 300 microseconds ( $\mu \mathrm{s})$. A narrow pulse length provides high resolution in shallow depths, but a wider pulse length provides maximum range with low-resolution images.

receiver gain Setting for the RESON SeaBat $^{\mathrm{TM}} 7125$ that controls the increase in the amplitude applied to the returned sonar signal in addition to the calculated time varied gain (TVG). The gain settings for the RESON SeaBat $^{\mathrm{TM}} 7125$ range from 0.0 to 83.0 decibels (dB).

roll Rotation of the boat about the alongtrack dimension.

survey matrix An empty grid which encompasses the multibeam survey area created in

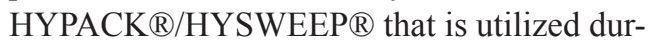
ing data collection to display real-time survey results.

swath A contiguous area of the lake, river, or ocean bottom that is surveyed as the boat makes one pass and is made up of numerous sonar pings. This area extends perpendicular from the boat dependent on multibeam settings and the water depth; for the RESON SeaBat 7125 this width is 128 degrees or approximately 4 times water depth.

transmit power Setting for the RESON SeaBat ${ }^{\mathrm{TM}} 7125$ that increases or decreases the amount of acoustic energy transmitted into the water. The RESON SeaBat ${ }^{\mathrm{TM}} 7125$ has a range from OFF to $220 \mathrm{~dB}$.

yaw Rotation of the boat about the vertical dimension. 
Publishing support provided by:

Rolla and West Trenton Publishing Service Centers

For more information concerning this publication, contact: Director, USGS Nebraska Water Science Center 5231 South 19th Street

Lincoln, NE 68512

(402) 328-4100

Or visit the Nebraska Water Science Center Web site at: http://ne.water.usgs.gov 



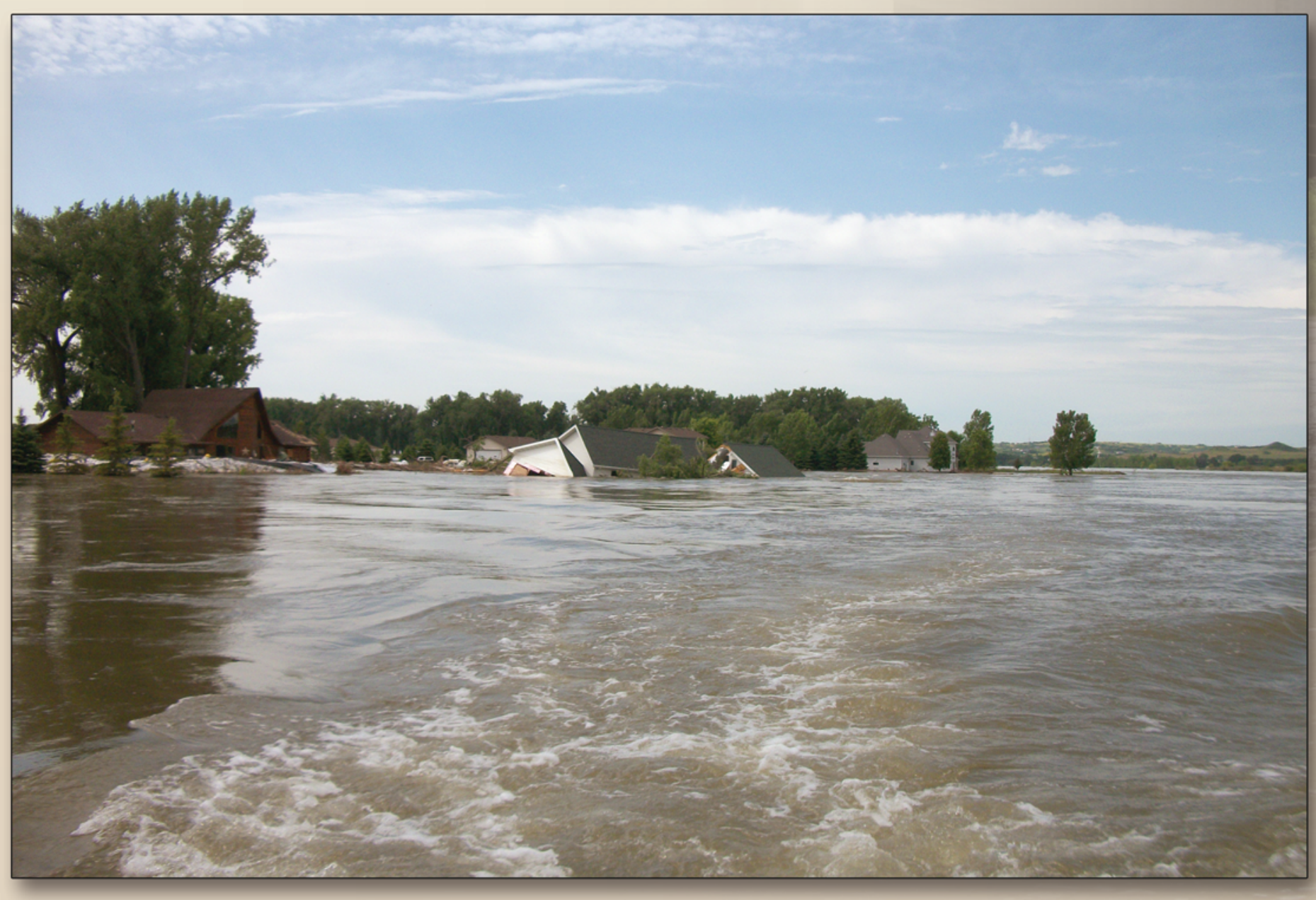

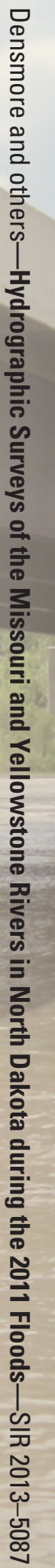

